\title{
The Use of Copper and Vanadium Mineral Ores in Catalyzed Mechanochemical Carbon-carbon Bond Formations
}

Francesco Puccetti, Christian Schumacher, Hermann Wotruba, José G. Hernández, Carsten Bolm Submitted date: 18/03/2020 - Posted date: 19/03/2020

Licence: CC BY-NC 4.0

Citation information: Puccetti, Francesco; Schumacher, Christian; Wotruba, Hermann; Hernández, José G.; Bolm, Carsten (2020): The Use of Copper and Vanadium Mineral Ores in Catalyzed Mechanochemical Carbon-carbon Bond Formations. ChemRxiv. Preprint. https://doi.org/10.26434/chemrxiv.12000171.v1

Under mechanochemical conditions in ball mills, copper-and vanadium-containing minerals initiate atom transfer radical cyclizations and oxidative couplings, respectively. Only catalytic quantities of the minerals are required, and the reactions proceed either under neat conditions or in the presence of a minimal amount of solvent.

File list (2)

Manuscript-ChemRxiv.pdf (897.32 KiB) view on ChemRxiv • download file 


\title{
The use of copper and vanadium mineral ores in catalyzed mechanochemical carbon-carbon bond formations
}

Francesco Puccetti,,$^{\dagger}$ Christian Schumacher, ${ }^{\dagger}$ Hermann Wotruba, ${ }^{\ddagger}$ José G. Hernández, ${ }^{\dagger *}$ and Carsten Bolm ${ }^{\dagger *}$

$\dagger$ Institute of Organic Chemistry, RWTH Aachen University, Landoltweg 1, D-52074 Aachen, Germany.

\$ Mineral Processing Unit (AMR), RWTH Aachen University, Lochnerstraße 4-20, 52064 Aachen, Germany

\section{Corresponding Authors:}

Jose.Hernandez@oc.rwth-aachen.de; Carsten.Bolm@oc.rwth aachen.de

\begin{abstract}
Under mechanochemical conditions in ball mills, copper- and vanadium-containing minerals initiate atom transfer radical cyclizations and oxidative couplings, respectively. Only catalytic quantities of the minerals are required, and the reactions proceed either under neat conditions or in the presence of a minimal amount of solvent.
\end{abstract}

In nature, minerals play a fundamental role as mediators and catalysts during the complex set of chemical reactions leading to the formation of hydrocarbons. ${ }^{1,2}$ This process generates structural complexity in light and heavier hydrocarbons, primarily through the formation and cleavage of carbon-carbon and carbon-hydrogen bonds. The ability of minerals to favor chemical reactions has been linked to their unique morphology and elemental composition, which consequently has inspired the design of materials resembling such structures. Recently, Fülöp and co-workers synthesized a $\mathrm{Ag}(\mathrm{I}) \mathrm{Bi}(\mathrm{III})$-containing hybrid material mirroring naturally occurring layered double minerals. ${ }^{3}$ The silver-containing hybrid exhibited outstanding catalytic properties in DMSO towards the synthesis of organic nitriles from terminal alkynes and trimethylsilyl azide. Complementarily, the direct use of minerals for catalysis has been reported as well. For instance, the earth-abundant mineral pyrite $\left(\mathrm{FeS}_{2}\right)$ proved to be catalytically active for the selective hydrogenation of a broad class of functionalized nitroarenes to substituted anilines in a reaction medium composed of $\mathrm{H}_{2} \mathrm{O}-\mathrm{THF},{ }^{4}$ thus exemplifying the potential of minerals in catalysis research. ${ }^{5}$

As in the geochemical formation of hydrocarbons, organic chemists use metals to facilitate the formation of new $\mathrm{C}-\mathrm{C}$ and $\mathrm{C}-\mathrm{H}$ bonds. However, unlike in nature, the use of minerals as catalysts 
in organic chemistry laboratories is far from being the mainstream choice. Practical hurdles such as the scarce solubility of minerals in commonly used reaction media may be responsible for the slow adoption of mineral-catalyzed organic transformations. Seeing the potential and the opportunities of recently implemented mechanochemical techniques to synthesize minerals ${ }^{6-9}$ and to facilitate the development of a myriad of reactions in organic chemistry, ${ }^{10-15}$ we started wondering about developing mechanochemical mineral-catalyzed transformations.

If achievable, such merging could clearly elevate the sustainability of mechanochemical reactions ${ }^{16}$ by harnessing the catalytic activity of bulk, readily available mineral ores, avoiding the need for the processing of the raw minerals into expensive metal catalysts. ${ }^{17-18} \mathrm{In}$ a proof-of-concept study, we have here focused on two mechanochemical carbon-carbon bond formation processes, namely, a copper-catalyzed atom transfer radical cyclization reaction and a vanadium-catalyzed oxidative coupling (Figure 1). As natural sources for the metals, a copper sulphide mineral named covellite and a vanadium-containing ore known as vanadinite were chosen for the mechanochemical reactions.

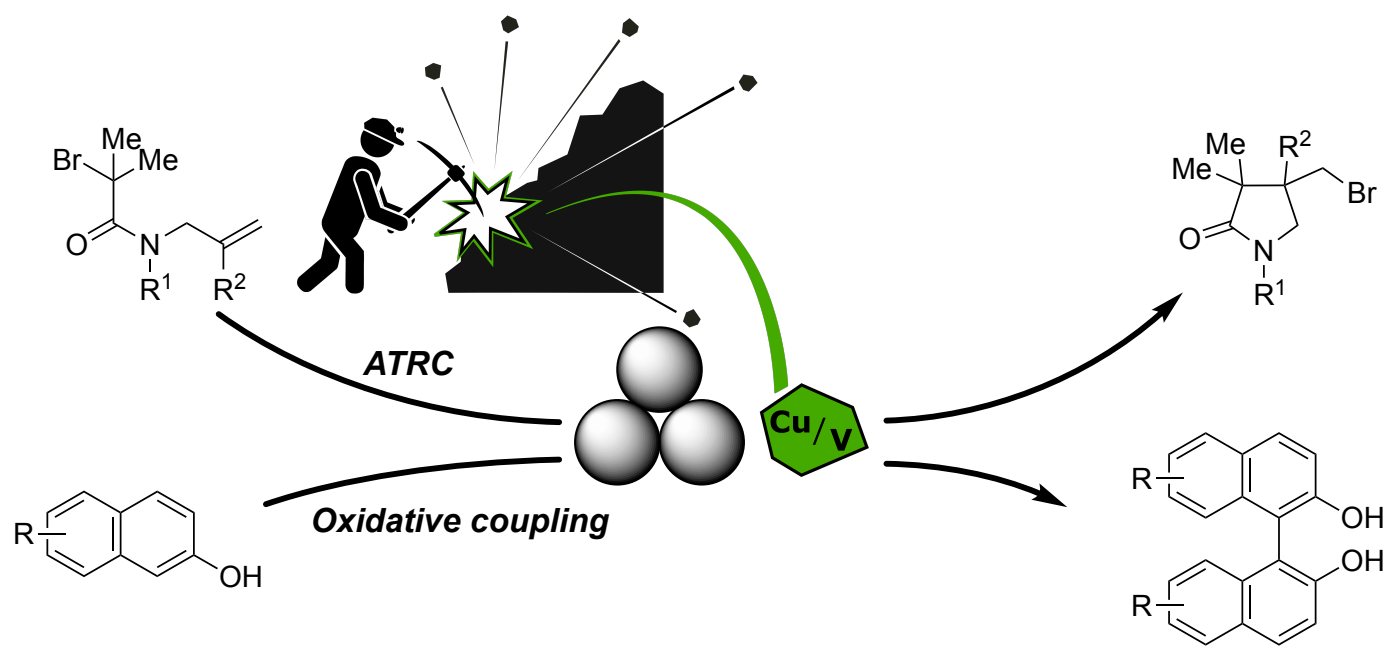

Figure 1. Use of raw mineral ores in copper-catalyzed atom transfer radical cyclization (ATRC) reactions and vanadium-catalyzed oxidative couplings under mechanochemical conditions.

As initial system, a copper-catalyzed atom transfer radical cyclization (ATRC) was selected. Commonly, this reaction is catalyzed by transition metals, being, in most cases, copper(I) salts and, particularly, copper(I) complexes bearing organic ligands. ${ }^{19}$ Here, we chose the mineral covellite, which, despite its elemental formula of CuS suggesting the presence of copper(II) ions, predominantly consists of copper(I) species represented as $\left(\mathrm{Cu}^{+}\right)_{3}\left(\mathrm{~S}^{2-}\right)\left(\mathrm{S}_{2}^{-}\right)$or $\left(\mathrm{Cu}^{+}\right)_{4}\left(\mathrm{Cu}^{2+}\right)_{2}\left(\mathrm{~S}_{2}\right)^{2-}$ ${ }_{2}\left(\mathrm{~S}^{2-}\right)_{2} \cdot{ }^{20-22}$ 
Table 1. Optimization of the reaction conditions: use of covellite in mechanochemical ATRC of 1a. ${ }^{a}$

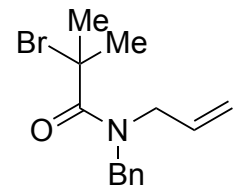

$1 \mathrm{a}$

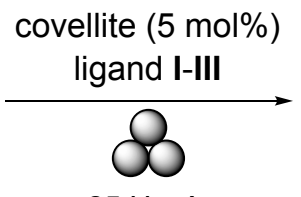

$25 \mathrm{~Hz}, \mathrm{Ar}$

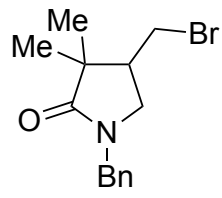

2a<smiles>c1ccc(-c2ccccn2)nc1</smiles>

I (bpy)<smiles>c1ccc(CN(Cc2ccccn2)Cc2ccccn2)nc1</smiles>

II (TPMA)

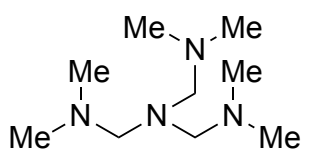

III $\left(\mathrm{Me}_{6}\right.$ TREN)

\begin{tabular}{llll}
\hline Entry & Ligand $(\mathrm{mol} \%)$ & Reaction time $(\min )$ & $\mathbf{2 a : 1 \mathbf { a } ^ { b }}$ \\
\hline 1 & none & 90 & n.r. \\
2 & I (20) & 90 & $13: 87$ \\
3 & II (20) & 90 & $80: 20$ \\
4 & III (20) & 90 & $>99: 1$ \\
5 & III (15) & 90 & $>99: 1$ \\
6 & III (10) & 90 & $>99: 1$ \\
7 & III (5) & 90 & $>99: 1$ \\
8 & III (2.5) & 90 & $91: 9$ \\
9 & III (5) & 60 & $>99: 1$ \\
$\mathbf{1 0}$ & III (5) & $\mathbf{3 0}$ & $>\mathbf{9 9 : 1}$ \\
11 & III (5) & 5 & $55: 45$ \\
$12^{c}$ & III (5) & 90 & n.r. \\
\hline${ }^{a}$ Rea
\end{tabular}

${ }^{a}$ Reaction conditions: 1a (100.0 mg, $\left.0.34 \mathrm{mmol}\right)$, covellite $(1.9 \mathrm{mg}, 0.02 \mathrm{mmol}, 5 \mathrm{~mol} \%)$ and ligand I-III were milled

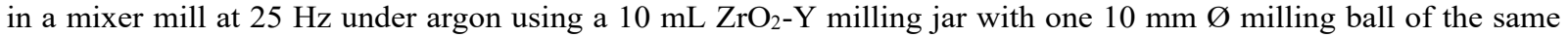
material. For calculations covellite was considered as pure $\mathrm{CuS}$. For an elemental analysis of the mineral samples, see ESI. ${ }^{b}$ Determined by ${ }^{1} \mathrm{H}$ NMR spectroscopy using signal integrals of 2a and 1a. ${ }^{c}$ Under air.

The first evaluation of the catalytic activity of covellite in a mechanochemical ATRC reaction involved neat grinding of amide 1a with the mineral under argon in a mixer mill for 90 min (Table 1, entry 1). To our disappointment, these conditions proved unsuitable, and none of the expected 5-exo-trig cyclization product $\mathbf{2 a}$ was observed. The outcome changed, when the experiment was performed in the presence of commonly used ligands I-III $(20 \mathrm{~mol} \%),{ }^{19}$ which resulted in the formation of significant amounts of lactam $\mathbf{2 a}$ identified by ${ }^{1} \mathrm{H}$ NMR spectroscopy of the crude mixture (Table 1, entries 2-4). In particular, tris[2-(dimethylamino)ethyl]amine ( $\mathrm{Me}_{6} \mathrm{TREN}$, III) proved effective leading to full conversion of $\mathbf{1 a}$ and exclusive formation of pyrrolidone $\mathbf{2 a}$. Reducing the amount of ligand III from $20 \mathrm{~mol} \%$ to $5 \mathrm{~mol} \%$ had no effect on the final ratio of 2a:1a, which remained $>99: 1$ (Table 1, entries 4-7). Applying only $2.5 \mathrm{~mol} \%$ of III lowered the product amount and the 2a:1a ratio changed to 91:9 (Table 1, entry 8). Shortening the milling time from 90 min to 30 min was possible without affecting the product/educt ratio (>99:1), but milling for only 5 min changed the 2a:1a ratio to 55:45 (Table 1, entries 9-11). Noteworthy, no product 
was observed when the argon atmosphere was changed to air (Table 1, entry 12). Performing the ATRC reaction under the optimized reaction conditions (Table 1, entry 10) allowed isolating product 2a in 94\% yield after column chromatography (Scheme 1). Carrying out the ATRC reaction under the optimized reaction conditions using $1.0 \mathrm{mmol}$ of $\mathbf{1 a}$ (ca. 3-fold scaled up) led to lactam $2 \mathbf{a}$ in $91 \%$ yield. The generality of the concept with respect to the mineral was shown by applying a combination of $\mathrm{Me}_{6} \mathrm{TREN}$ and bornite $\left(\mathrm{Cu}_{5} \mathrm{FeS}_{4}\right)^{23}$ instead of covellite, which provided lactam $\mathbf{2 a}$ from amide $\mathbf{1 a}$ in $97 \%$ yield.

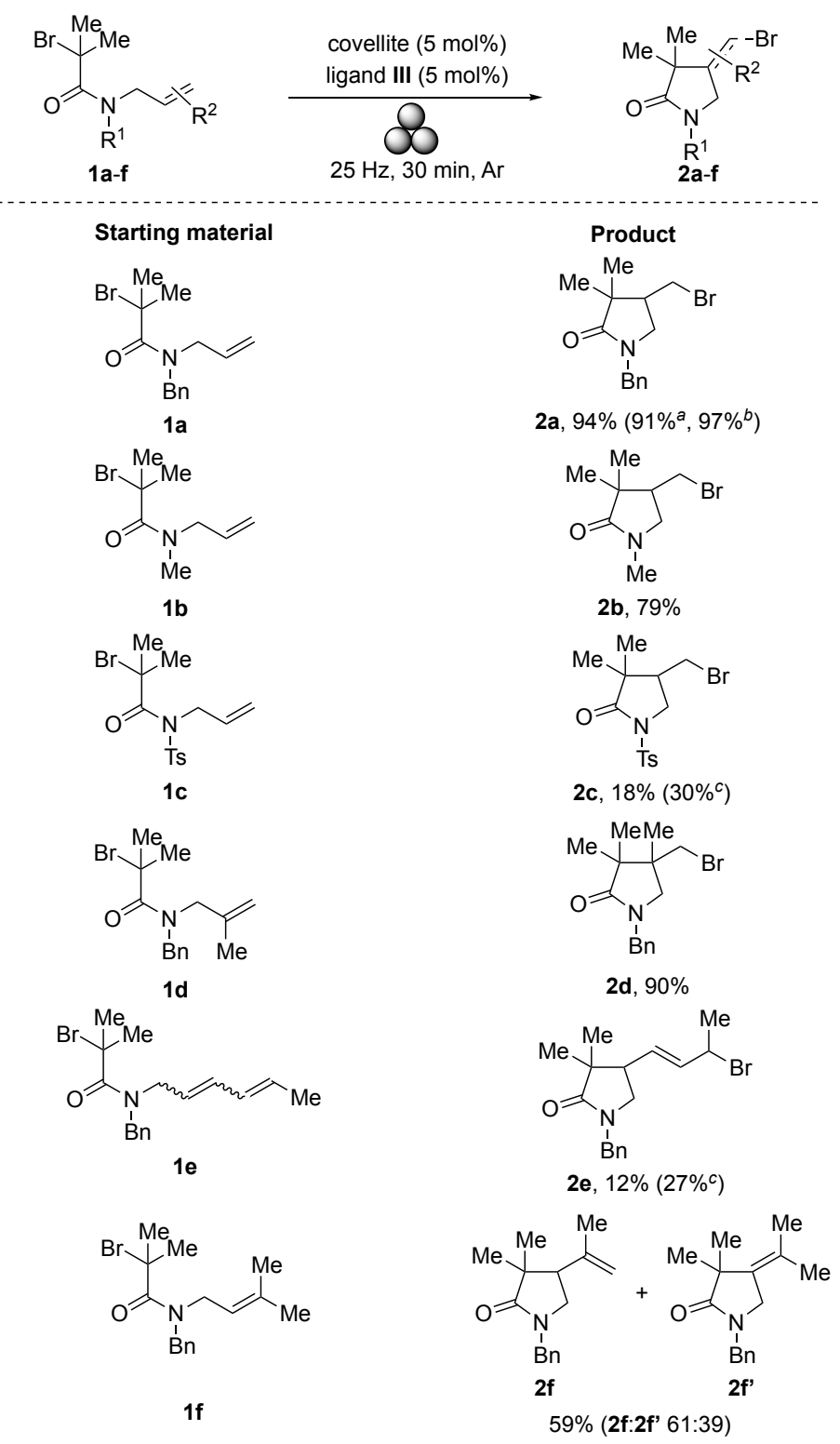

Scheme 1. Scope of the ATRC reaction. Reaction conditions: 1a-f $(0.3 \mathrm{mmol}$ or $100.0 \mathrm{mg})$, covellite $(0.02 \mathrm{mmol}, 5 \mathrm{~mol} \%)$ and

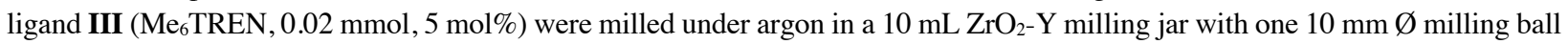
of the same material for $30 \mathrm{~min}$ at $25 \mathrm{~Hz}$. For calculations covellite was considered as pure CuS. For an elemental analysis of the mineral samples, see ESI. ${ }^{\text {a }}$ Reaction conducted on $1.0 \mathrm{mmol}$ scale of 1a. ${ }^{\mathrm{b}}$ Bornite mineral was used instead of covellite. ${ }^{\mathrm{c}} 90 \mathrm{~min}$ of milling. 
To further test the applicability of the mechanochemical ATRC reaction, the study was extended to amides 1b-f, which were subjected to millings with covellite and $\mathrm{Me}_{6}$ TREN (Scheme 1). As $N$ benzyl derivative 1a, also $N$-methyl- and $N$-tosyl-substituted amides $\mathbf{1 b}$ and $\mathbf{1 c}$, respectively, underwent the cyclization reaction, although to a lesser extend compared to their $N$-benzyl analogue (Scheme 1). Probably, as shown in previous studies, ${ }^{24,25}$ the steric and electronic effects of the $N$-substituent affected the population of the required anti-amide conformer, thereby lowering the overall reaction efficiency. As studied for the conversion of $\mathbf{1 c}$, extending the reaction time had a positive effect on the yield of $\mathbf{2 c}$, which increased from $18 \%$ to $30 \%$ when the reaction was performed for $90 \mathrm{~min}$ instead of the standard $30 \mathrm{~min}$ (Scheme 1). Next, three other $N$-benzyl amides (1d-f) were tested. The results were mixed. While 1d exhibited a similar reactivity as 1a providing $\mathbf{2 d}$ in $90 \%$ yield, $\mathbf{1 e}$ reacted sluggish, leading to lactam $\mathbf{2 e}$ in only $12 \%$ yield under standard conditions. As observed before, extending the reaction time proved beneficial, and after 90 min of milling $2 \mathbf{e}$ was isolated in $27 \%$ yield. The results for the latter substrate were attributed to the pronounced stability of the presumed allyl radical being formed as intermediate after the initial cyclization step of $\mathbf{1 e}$ and its reduced rate in bromide transfer closing the catalytic cycle (see ESI). ${ }^{26}$ Finally, applying amide $\mathbf{1 f}$ in the mechanochemical ATRC reaction afforded bromine-free isomeric lactams $\mathbf{2 f}$ and $\mathbf{2} \mathbf{f}^{\prime}$ in 59\% overall yield. Most likely, both compounds resulted from the same cyclization product having a 2-bromo-2-propyl substituent. Subsequent $\mathrm{HBr}$ elimination gave olefinic products $\mathbf{2} \mathbf{f}$ and $\mathbf{2} \mathbf{f}^{\prime}$ (in a ratio of 61:39).

With the goal to validate the concept of using minerals in mechanosynthesis by a second example, the vanadium-promoted oxidative coupling of $\beta$-naphthol (3a) was set into the focus. ${ }^{27,28}$ The relatively high abundance of vanadium on earth compared to other transition metals has encouraged many studies on vanadium catalysis under homogeneous ${ }^{27}$ and heterogeneous ${ }^{29}$ reaction conditions. However, to the best of our knowledge, the direct use of a vanadiumcontaining mineral as catalyst for an organic reaction has remained unknown. For this part of the proof-of-concept study, we chose vanadinite $\left[\mathrm{Pb}_{5}\left(\mathrm{VO}_{4}\right)_{3} \mathrm{Cl}\right]$ being one of the most abundant vanadium-based minerals and therefore a primary source of this metal at the industrial level. ${ }^{30} \mathrm{By}$ using vanadinite in combination with dioxygen under mechanical milling we envisaged promoting the oxidative coupling of 3a to 1,1'-bi-2-naphthol (BINOL, 4a) (Table 2), while expanding the applicability of ball milling techniques to mechanochemical reactions involving gaseous reactants. ${ }^{31-35}$

As in the case of the covellite-catalyzed ATRC reaction, the presence of an organic ligand proved critical here too. While in both the absence of vanadinite and the presence of the mineral alone the conversion of $\mathbf{3 a}$ to $\mathbf{4 a}$ was $\leq 1 \%$ (Table 2, entries 1 and 2), the product formation was triggered by the addition of an organic acid (entries 3-7). Testing a series of acidic additives showed that (at $1 \mathrm{~atm}$ of dioxygen pressure) multicarboxylic acids such as tartaric acid and citric acid were superior over, for example, simple amino acids (see ESI for details). Finally, the presence of 2,6-dipicolinic acid (DPA $)^{36}$ led to be best result giving a 24:76 mixture of $4 \mathbf{a}$ and $\mathbf{3 a}$ after $2 \mathrm{~h}$ of milling at 600 
Table 2. Optimization of the reaction conditions: use of vanadinite in mechanochemical oxidative coupling of $3 \mathbf{a}^{\mathrm{a}}$

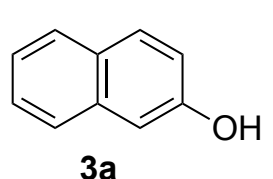

3a

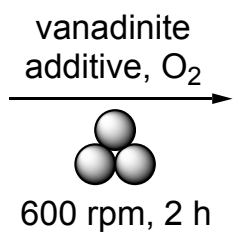

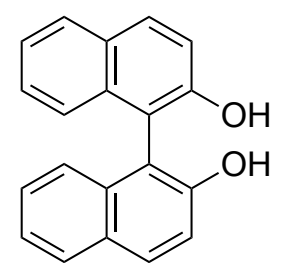

$4 a$

\begin{tabular}{|c|c|c|c|}
\hline Entry & $\mathrm{O}_{2}(\mathrm{~atm})$ & Additive $^{b}$ & $4 \mathbf{a}: 3 \mathbf{a}^{c}$ \\
\hline $1^{d}$ & 1.0 & None & $0: 100$ \\
\hline 2 & 1.0 & None & 1:99 \\
\hline 3 & 1.0 & Glutamic acid & 3:97 \\
\hline 4 & 1.0 & Aspartic acid & 8:92 \\
\hline 5 & 1.0 & Tartaric acid & 7:93 \\
\hline 6 & 1.0 & Citric acid & 4:96 \\
\hline 7 & 1.0 & DPA & $24: 76$ \\
\hline 8 & 4.0 & DPA & $33: 67$ \\
\hline 9 & 4.0 & DPA, LAG $(\mathrm{MeOH}, \eta=0.5)$ & $87: 13$ \\
\hline $10^{e}$ & 4.0 & DPA, LAG (MeOH, $\eta=0.5)$ & 89:11 \\
\hline $11^{f}$ & 4.0 & DPA, LAG $(\mathrm{MeOH}, \eta=0.5)$ & $68: 32$ \\
\hline
\end{tabular}

${ }^{a}$ Reaction conditions: 3a (100.0 mg, $\left.0.69 \mathrm{mmol}\right)$, vanadinite $(1.0 \mathrm{~g}$, equivalent to $1.70 \mathrm{mmol}$ of vanadium) and additive $(300.0 \mathrm{mg})$ were milled in a planetary ball mill under dioxygen in a $20 \mathrm{~mL} \mathrm{ZrO}_{2}-\mathrm{Mg}$ milling jar with five $10 \mathrm{~mm} \varnothing$ balls of the same material for $2 \mathrm{~h}$ at $600 \mathrm{rpm}(1 \mathrm{~h} \times 2 ; 20 \mathrm{~min}$ pause after each milling cycle). For an elemental analysis of the mineral sample, see ESI. ${ }^{b} \eta$ is the volume of solvent (in $\mu \mathrm{L}$ ) divided by the total weight of the solid reactants (in mg). ${ }^{c}$ Determined by ${ }^{1} \mathrm{H}$ NMR spectroscopy using signal integrals of 4a and 3a. ${ }^{d}$ Without vanadinite. ${ }^{e}$ Use of $500.0 \mathrm{mg}$ of vanadinite $(0.85 \mathrm{mmol}$ of vanadium $)$ and $150.0 \mathrm{mg}$ of DPA $(0.90 \mathrm{mmol}) .{ }^{f}$ Use of $250.0 \mathrm{mg}$ of vanadinite $(0.42 \mathrm{mmol}$ of vanadium $)$ and $75 \mathrm{mg}$ of DPA $(0.45 \mathrm{mmol})$.

rpm (Table 2, entry 7). Increasing the dioxygen pressure inside the milling vessel from 1 atm to 4 atm raised the product amount $(\mathbf{4 a : 3 a}=33: 67$; Table 2, entry 8). A further improvement was noted upon liquid-assisted grinding (LAG) ${ }^{37}$ with methanol (Table 2, entry 9). The benefits of the LAG approach included reducing the vanadinite loading below stoichiometric amounts of vanadium, thereby achieving an oxidative coupling of $\beta$-naphthol (3a) in the ball mill under vanadinite catalysis (Table 2, entry 11). Intrigued by the remarkable effect of methanol on the mechanochemical reaction, LAG experiments with other liquid additives were carried out (Table 3 ). The screening revealed that the entire system was highly sensitive to even small changes. For example, adding $\mathrm{MeOH}-d_{4}$ instead of $\mathrm{MeOH}$ changed the yield of $\mathbf{4 a}$ (as determined by ${ }^{1} \mathrm{H} \mathrm{NMR}$ spectroscopy with an internal standard) from 64\% to 36\% (Table 3, entries 2 and 3). Negative effects on the yield of $\mathbf{4 a}$ were also noted when other common solvents were added (Table 3 , entries 4-11). Finally, the amounts of methanol and DPA were fine-tuned to maximize the effects (Table 3, entries 12-15). 
Table 3. LAG effects upon addition of liquids to the vanadinite-catalyzed oxidative coupling of $\mathbf{3 a} .^{\mathrm{a}}$

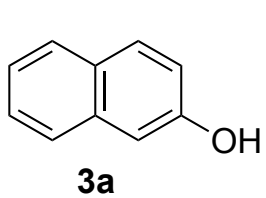

vanadinite ( 0.6 equiv) DPA, $\mathrm{O}_{2}(4.0 \mathrm{~atm})$

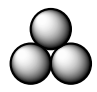

$600 \mathrm{rpm}, 2 \mathrm{~h}$<smiles>Oc1ccc2ccccc2c1-c1c(O)ccc2ccccc12</smiles>

4a

\begin{tabular}{lll}
\hline Entry & LAG additive $(\eta)$ & Yield of $\mathbf{4 a}(\%)^{b}$ \\
\hline 1 & --- & $39 \%$ \\
2 & $\mathrm{MeOH}(0.5)$ & $64 \%$ \\
3 & $\mathrm{MeOH}-d_{4}(0.5)$ & $36 \%$ \\
4 & $\mathrm{EtOH}(0.5)$ & $45 \%$ \\
5 & $\mathrm{CCl}(0.5)$ & $42 \%$ \\
6 & $i-\operatorname{PrOH}(0.5)$ & $12 \%$ \\
7 & $\mathrm{HFIP}(0.5)$ & $10 \%$ \\
8 & $\mathrm{H} 2 \mathrm{O}(0.5)$ & $12 \%$ \\
9 & $\mathrm{DMSO}(0.5)$ & $7 \%$ \\
10 & $\mathrm{DMF}(0.5)$ & $7 \%$ \\
11 & $\mathrm{MeCN}(0.5)$ & $11 \%$ \\
$12^{c}$ & $\mathrm{MeOH}(0.5)$ & $63 \%$ \\
$13^{c}$ & $\mathrm{MeOH}(0.2)$ & $50 \%$ \\
$14^{c}$ & $\mathrm{MeOH}(0.1)$ & $33 \%$ \\
$\mathbf{1 5}^{c}$ & $\mathrm{MeOH}(\mathbf{0 . 0 5})$ & $\mathbf{6 3} \%$
\end{tabular}

${ }^{a}$ Reaction conditions: 3a (100.0 mg; $\left.0.69 \mathrm{mmol}\right)$, vanadinite $(250.0 \mathrm{mg} ; 0.42 \mathrm{mmol}$ of vanadium), DPA (75.0 $\mathrm{mg} ; 0.45 \mathrm{mmol})$ and the LAG solvent were milled under $\mathrm{O}_{2}(4.0 \mathrm{~atm})$ in a planetary ball mill using a $20 \mathrm{~mL}$ $\mathrm{ZrO}_{2}-\mathrm{Mg}$ milling jar with five $10 \mathrm{~mm} \varnothing$ milling balls of the same material for $2 \mathrm{~h}$ at $600 \mathrm{rpm}(1 \mathrm{~h} \times 2 ; 20 \mathrm{~min}$ pause after each milling cycle). For an elemental analysis of the mineral sample, see ESI. ${ }^{b}$ Determined by ${ }^{1} \mathrm{H}$ NMR spectroscopy using 1,3,5-trimethoxybenzene as an internal standard. ${ }^{c}$ Use of $0.42 \mathrm{mmol}$ of DPA.

After having identified the best additive combination (DPA and $\mathrm{MeOH}$ ), the vanadinite-catalyzed oxidative coupling of $\mathbf{3 a}$ was carried out for $8 \mathrm{~h}$ of milling, which allowed to isolate of product $\mathbf{4 a}$ in $86 \%$ yield (Scheme 2). Other naphthol derivatives showed a similar reactivity. For instance, the use of 7-methoxy 2-naphthol (3b) gave substituted BINOL $\mathbf{4 b}$ in 96\%. Bromo-substituted naphthols 3c and 3d proved less reactive affording the corresponding BINOLs $\mathbf{4 c}$ and $\mathbf{4 d}$ in yield of $53 \%$ and $36 \%$, respectively (Scheme 2). Employing 3e and 3f with 6-aryl substituents led to yields of $72 \%$ for $\mathbf{4 e}$ and $30 \%$ for $\mathbf{4 f}$. Overall, the results indicated that both electronic and steric 
effects of the substrates have an impact of the coupling efficiency. In addition, solid-state properties (such as crystallinity) of both reactants and the products play a role..$^{38}$

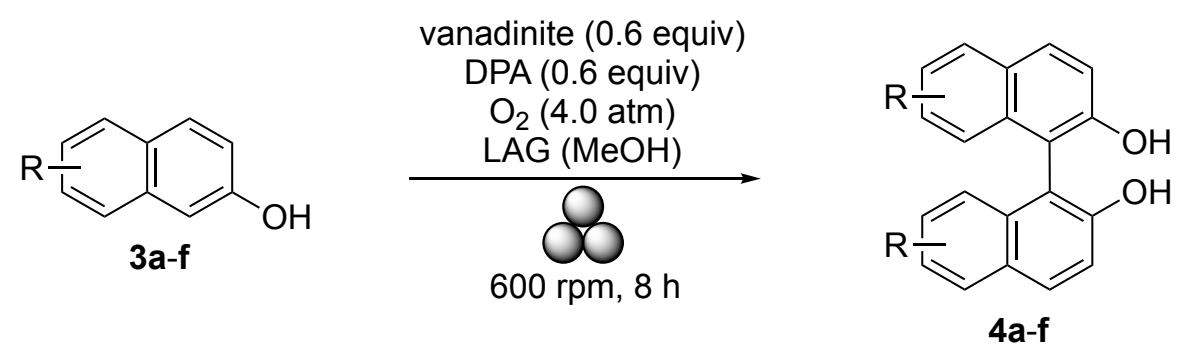<smiles>Oc1ccc2ccccc2c1-c1c(O)ccc2ccccc12</smiles>

$4 a, 86 \%$<smiles>Oc1c(Br)cc2ccccc2c1-c1c(O)c(Br)cc2ccccc12</smiles>

4d, $36 \%$<smiles>COc1ccc2ccc(O)c(-c3c(O)ccc4ccc(OC)cc34)c2c1</smiles>

4b, $96 \%$<smiles>[R6]c1ccc(O)c(-c2c(O)ccc3cc(-c4ccccc4)ccc23)c1C#[Y6]</smiles><smiles>Oc1ccc2cc(Br)ccc2c1-c1c(O)ccc2cc(Br)ccc12</smiles>

4c, $53 \%$<smiles>CC(C)(C)O[Na]</smiles>

Scheme 2. Scope of the mechanochemical vanadium-catalyzed oxidative coupling. Reaction conditions: $3 a-f(0.70 \mathrm{mmol})$, vanadinite $(252.5 \mathrm{mg} ; 0.43 \mathrm{mmol})$, DPA $(71.5 \mathrm{mg}, 0.43 \mathrm{mmol})$ and methanol $(\eta=0.05)$ were milled under dioxygen in a planetary ball mill using a $20 \mathrm{~mL} \mathrm{ZrO}_{2}-\mathrm{Mg}$ milling jar with five $10 \mathrm{~mm} \varnothing$ milling balls of the same material for $8 \mathrm{~h}$ at $600 \mathrm{rpm}(1 \mathrm{~h} \times 8 ; 20 \mathrm{~min}$ pause after each milling cycle). For an elemental analysis of the mineral sample, see ESI.

In summary, we have demonstrated the potential of using raw mineral ores as catalysts in coppercatalyzed atom transfer radical cyclizations and vanadium-catalyzed oxidative couplings. Both carbon-carbon bond forming processes occurred in mixer and planetary ball mills, which enabled the reactions to proceed mechanochemically. Moreover, the implementation of ball milling techniques permitted the poorly soluble copper and vanadium minerals (i.e., covellite, bornite and vanadinite) to promote the reactions under neat and LAG conditions. Such approach significantly reduced mineral processing operations typically required to access commercial metal salts, by directly using mineral ores as catalysts in ball mills. Key to harness the catalytic activity of the metals within the minerals was the use of readily available organic ligands such as $\mathrm{Me}_{6} \mathrm{TREN}_{\mathrm{T}}$ DPA. Thus, the approach avoided the need for highly engineered ligands or additive. Currently, this concept is further investigated in our laboratories applying it in other mechanochemical reactions, catalyzed by mineral ores. 
Supporting Information. The following files are available free of charge. Experimental synthetic procedures and characterization $\left({ }^{1} \mathrm{H}\right.$ and ${ }^{13} \mathrm{C}$ NMR, IR, MS (EI,CI)) of compounds 1a-f, 2a-f, 3e-f and 4a-f; HRMS data for compounds $\mathbf{1 b}-\mathbf{f}$ and $\mathbf{2 b - f}$; extended version of Table 2; considerations on the mechanism for the formation of $\mathbf{2 e}$.

\section{Author Contributions}

The manuscript was written through contributions of all authors. All authors have given approval to the final version of the manuscript.

\section{ACKNOWLEDGMENT}

The authors gratefully acknowledge RWTH Aachen University and the German Research Foundation (DFG; project BO 823/16-1) for financial support. CS is grateful for a Kekulé scholarship from Verband der Chemischen Industrie e.V. We also acknowledge M. Müller (RWTH Aachen University) for the access to PXRD and the technical assistance. FP is grateful to S. Vasanthakumar (RWTH Aachen University) for the experimental support.

\section{REFERENCES}

(1) Seewald, J. S. Organic-inorganic interactions in petroleum-producing sedimentary basins. Nature 2003, 426, 327-333. DOI: 10.1038/nature02132.

(2) Kolesnikov, A.; Kutcherov, V. G.; Goncharov, A. F. Methane-derived hydrocarbons produced under upper-mantle conditions. Nature Geoscience 2009, 2, 566-570. DOI: $10.1038 /$ ngeo591.

(3) Ötvös, S. B.; Mészáros, R.; Varga, G.; Kocsis, M.; Kónya, Z.; Kukovecz, Á.; Pusztai, P.; Sipos, P.; Pálinkó, I.; Fülöp, F. A mineralogically-inspired silver-bismuth hybrid material: an efficient heterogeneous catalyst for the direct synthesis of nitriles from terminal alkynes. Green Chem. 2018, 20, 1007-1019. DOI: 10.1039/C7GC02487H.

(4) Morse, J. R.; Callejas, J. F.; Darling, A. J.; Schaak, R. E. Bulk iron pyrite as a catalyst for the selective hydrogenation of nitroarenes. Chem. Commun. 2017, 53, 4807-4810. DOI: 10.1039/C7CC00120G.

(5) Theng, B. K. G. Clay Mineral Catalysis of Organic Reactions; CRC Press: Boca Raton, 2018. 
(6) Zahrani, E. M.; Fathi, M. H. The effect of high-energy ball milling parameters on the preparation and characterization of fluorapatite nanocrystalline powder. Ceram. Int. 2009, 35, 2311-2323. DOI: 10.1016/j.ceramint.2009.01.012.

(7) Wu, S.-C.; Hsu, H.-C.; Hsu, S.-K.; Chang, Y.-C.; Ho, W .-F. J. Synthesis of hydroxyapatite from eggshell powders through ball milling and heat treatment. Asian Ceram. Soc. 2016, 4, 8590. DOI: $10.1016 /$ j.jascer.2015.12.002.

(8) Li, S.; Huskić, I.; Novendra, N.; Titi, H. M.; Navrotsky, A.; Friščić, T. Mechanochemical Synthesis, Accelerated Aging, and Thermodynamic Stability of the Organic Mineral Paceite and Its Cadmium Analogue. ACS Omega 2019, 4, 5486-5495. DOI: 10.1021/acsomega.9b00295.

(9) Sharma, L.; Kiani, D.; Honer, K.; Baltrusaitis, J. Mechanochemical Synthesis of Ca- and Mg-Double Salt Crystalline Materials Using Insoluble Alkaline Earth Metal Bearing Minerals. ACS Sustain. Chem. Eng. 2019, 7, 6802-6812. DOI: 10.1021/acssuschemeng.8b06129.

(10) Zhang, Z.-Y.; Ji, D.; Mao, W.; Cui, Y.; Wang, Q.; Han, L.; Zhong, H.; Wei, Z.; Zhao, Y .; Nørgaard K.; Li, T. Dry Chemistry of Ferrate (VI): A Solvent-Free Mechanochemical Way for Versatile Green Oxidation. Angew. Chem. Int. Ed. 2018, 57, 10949-10953. DOI: 10.1002/anie.201805998.

(11) Bolm, C.; Mocci, R.; Schumacher, C.; Turberg, M.; Puccetti F.; Hernández, J. G.; Mechanochemical Activation of Iron Cyano Complexes: A Prebiotic Impact Scenario for the Synthesis of $\alpha$-Amino Acid Derivatives. Angew. Chem. Int. Ed. 2018, 57, 2423-2426. DOI: 10.1002/anie.201713109.

(12) Turberg, M.; Ardila-Fierro, K. J.; Bolm C.; Hernández, J. G. Altering Copper-Catalyzed $\mathrm{A}^{3}$ Couplings by Mechanochemistry: One-Pot Synthesis of 1, 4-Diamino-2-butynes from Aldehydes, Amines, and Calcium Carbide. Angew. Chem. Int. Ed. 2018, 57, 10718-10722. DOI: 10.1002/anie.201805505.

(13) Ardila-Fierro, K. J.; Bolm C.; Hernández, J. G.; Mechanosynthesis of Odd-Numbered Tetraaryl $[n]$ cumulenes. Angew. Chem. Int. Ed. 2019, 58, 12945-12949. DOI: 10.1002/anie.201905670.

(14) Cao, Q.; Crawford, D. E.; Shi, C.; James, S. L. Greener dye synthesis: Continuous, solventfree synthesis of commodity perylene diimides by Twin Screw Extrusion. Angew. Chem. Int. Ed. 2020, 59, 4478-4483. DOI: 10.1002/anie.201913625.

(15) Peters, D. W.; Blair, R. G.; Mechanochemical synthesis of an organometallic compound: a high volume manufacturing method. Faraday Discuss. 2014, 170, 83-91. DOI: 10.1039/C3FD00157A. 
(16) Erythropel, H. C.; Zimmerman, J. B.; de Winter, T. M.; Petitjean, L.; Melnikov, F.; Lam, C. H.; Lounsbury, A. W.; Mellor, K. E.; Janković, N. Z.; Tu, Q.; Pincus, L. N.; Falinski, M. M.; Shi, W.; Coish, P.; Plata, D. L.; Anastas, P. T. The Green ChemisTREE: 20 years after taking root with the 12 principles. Green Chem. 2018, 20, 1929-1961. DOI: 10.1039/C8GC00482J.

(17) Vogt, C. G.; Grätz, S.; Lukin, S.; Halasz, I.; Etter, M.; Evans J. D.; Borchardt, L.; Direct Mechanocatalysis: Palladium as Milling Media and Catalyst in the Mechanochemical Suzuki Polymerization. Angew. Chem. Int. Ed. 2019, 58, 18942-18947. DOI: doi.org/10.1002/anie.201911356.

(18) Haley, A. R.; Mack J.; Guan H. 2-in-1: catalyst and reaction medium. Inorg. Chem. Front. 2017, 4, 52-55. DOI: 10.1039/C6QI00400H.

(19) Clark, A. J. Copper Catalyzed Atom Transfer Radical Cyclization Reactions. Eur. J. Org. Chem. 2016, 2231-2243. DOI: 10.1002/ejoc.201501571.

(20) Liang W.; Whangbo, M.-H.; Conductivity anisotropy and structural phase transition in covellite CuS. Solid State Commun. 1993, 85, 405-408. DOI: 10.1016/0038-1098(93)90689-K.

(21) Goble, R. J. The relationship between crystal structure, bonding and cell dimensions in the copper sulfides. Can. Mineralogist 1985, 23, 61-76.

(22) Evans Jr., H. T.; Konnert, J. A. Crystal structure refinement of covellite. Am. Mineral. 1976, 61, 996-1000.

(23) Morimoto, N.; Kullerud, G.; Polymorphism in bornite. Am. Mineral. 1961, 46, 1270-1282.

(24) Ishibashi, H.; So, T. S.; Okochi, K.; Sato, T.; Nakamura, N.; Nakatani, H.; Ikeda, M. Radical Cyclization of $N$-(Cyclohex-2-enyl)- $\alpha, \alpha$-dichloroacetamides. Stereoselective Syntheses

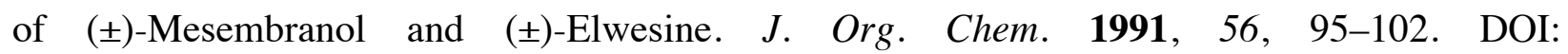
10.1021/jo00001a021.

(25) Iwamatsu, S.-I.; Matsubara, K.; Nagashima, H. Synthetic Studies of cis-3aAryloctahydroindole Derivatives by Copper-Catalyzed Cyclization of $\mathrm{N}$ Allyltrichloroacetamides: Facile Construction of Benzylic Quaternary Carbons by Carbon-Carbon Bond-Forming Reactions. J. Org. Chem. 1999, 64, 9625-9631. DOI: 10.1021/jo9912146.

(26) Walling, C. Some properties of radical reactions important in synthesis. Tetrahedron 1985, 41, 3887-3900. DOI: 10.1016/S0040-4020(01)97172-8. 
(27) Langeslay, R. R.; Kaphan, D. M.; Marshall, C. L.; Stair, P. C.; Sattelberger A. P.; Delferro, M. Catalytic applications of vanadium: a mechanistic perspective. Chem. Rev. 2019, 119, 21282191. DOI: 10.1021/acs.chemrev.8b00245.

(28) Rasmussen, M. O.; Axelsson, O.; Tanner, D. A. Practical Procedure for the Solid-Phase Synthesis of Racemic 2,2'-Dihydroxy-1,1'-binaphthyl. Synth. Commun. 1997, 27, 4027-4030. DOI: $10.1080 / 00397919708005446$.

(29) Weckhuysen, B. M.; Keller, D. E. Chemistry, spectroscopy and the role of supported vanadium oxides in heterogeneous catalysis. Catal. Today 2003, 78, 25-46. DOI: 10.1016/S09205861(02)00323-1.

(30) Anthony, J. W.; Bideaux, R. A.; Bladh, K. W.; Nichols, M. C. Handbook of Mineralogy, Volume IV. Arsenates, Phosphates, Vanadates; Mineral Data Publishing: Tucson (AZ), 2000.

(31) Beillard, A.; Métro, T.-X.; Bantreil, X.; Martinez J.; Lamaty, F. Cu(0), $\mathrm{O}_{2}$ and mechanical forces: a saving combination for efficient production of $\mathrm{Cu}-\mathrm{NHC}$ complexes. Chem. Sci. 2017, 8, 1086-1089. DOI: 10.1039/C6SC03182J.

(32) Ardila-Fierro, K. J.; Pich, A.; Spehr, M.; Hernández J. G.; Bolm, C. Synthesis of acylglycerol derivatives by mechanochemistry. Beilstein J. Org. Chem. 2019, 15, 811-817. DOI: 10.3762/bjoc.15.78.

(33) van Bonn, P.; Bolm C.; Hernández, J. G. Mechanochemical Palladium-Catalyzed Carbonylative Reactions Using $\mathrm{Mo}(\mathrm{CO})_{6}$. Chem. Eur. J. 2020, 26, 2576-2580. DOI: 10.1002/chem.201904528.

(34) Brekalo, I.; Yuan, W.; Mottillo, C.; Lu, Y.; Zhang, Y.; Casaban, J.; Holman, K. T.; James, S. L.; Duarte, F.; Williams, P. A.; Harris, K. D. M.; Friščić, T. Manometric real-time studies of the mechanochemical synthesis of zeolitic imidazolate frameworks. Chem. Sci. 2020, 11, 2141-2147. DOI: $10.1039 / \mathrm{c} 9 \mathrm{sc} 05514 \mathrm{~b}$.

(35) Bolm, C.; Hernández, J. G. Mechanochemistry of Gaseous Reactants. Angew. Chem. Int. Ed. 2019, 58, 3285-3299. DOI: 10.1002/anie.201810902.

(36) Kirillov, A. M.; Shul'pin, G. B. Pyrazinecarboxylic acid and analogs: Highly efficient cocatalysts in the metal-complex-catalyzed oxidation of organic compounds. Coord. Chem. Rev. 2013, 257, 732-754. DOI: 10.1016/j.ccr.2012.09.012.

(37) Friščić, T.; Childs, S. L.; Rizvi, S. A.; Jones, W. The role of solvent in mechanochemical and sonochemical cocrystal formation: a solubility-based approach for predicting cocrystallisation outcome. CrystEngComm 2009, 11, 418-426. DOI: 10.1039/B815174A. 
(38) Schneider, F.; Szuppa, T.; Stolle, A.; Ondruschka, B.; Hopf, H. Energetic assessment of the Suzuki-Miyaura reaction: a curtate life cycle assessment as an easily understandable and applicable tool for reaction optimization. Green Chem. 2009, 11, 1894-1899. DOI: 10.1039/B915744C. 


\title{
Supporting Information
}

\section{The use of copper and vanadium mineral ores in catalyzed mechanochemical carbon-carbon bond formations}

\author{
Francesco Puccetti, ${ }^{a}$ Christian Schumacher, ${ }^{a}$ Hermann Wotruba, ${ }^{b}$ José G. Hernández, ${ }^{a *}$ and Carsten Bolm ${ }^{\mathrm{a} *}$ \\ ${ }^{a}$ Institute of Organic Chemistry, RWTH Aachen University, Landoltweg 1, 52074 Aachen, Germany \\ ${ }^{\mathrm{b}}$ Mineral Processing Unit (AMR), RWTH Aachen University, Lochnerstraße 4-20, 52064 Aachen, Germany
}

\section{Table of Content}

1. General information $\quad$ S2

2. Mineral processing $\quad$ S3

3. Synthesis of substrates 1a-f $\quad$ S3

4. Mechanochemical synthesis of 2a-f $\quad$ S10

5. Considerations on the mechanism for the formation of $\mathbf{2 e} \quad S 15$

$\begin{array}{ll}\text { 6. Synthesis of substrate 3e-f } & \text { S16 }\end{array}$

$\begin{array}{ll}\text { 7. Mechanochemical synthesis of 4a-f } & \text { S17 }\end{array}$

$\begin{array}{ll}\text { 8. References } & \text { S23 }\end{array}$

9. NMR spectra $\quad$ S24

10. PXRD and elemental analysis of the minerals used in this work $\quad$ S51 


\section{General information}

Building blocks were commercially available and were used as received unless otherwise stated. Raw vanadinite samples were provided by the Mineral Processing Unit (AMR) RWTH Aachen University, and samples of covellite and bornite were purchased at a local mineral store. The elemental analysis of the minerals used was carried by the company ALS geochemistry (at the Loughrea, Co. Galway facility) and was performed by acid digestion followed by ICP-AES analysis; resulting data can be found in the Appendix 1 of the present document. Thin-layer chromatography (TLC) was performed using TLC plates (silica gel 60 on aluminum plates with fluorescence indicator F254) from MERCK. Qualitative analysis of the TLC plates was carried out using UV light ( $\lambda=254 \mathrm{~nm}$ and/or $\lambda=366 \mathrm{~nm}$ ) and/or by immersion in an aqueous solution of potassium permanganate $\left(\mathrm{KMnO}_{4}\right)$ and heating of the stained plates with a heat-gun at $300{ }^{\circ} \mathrm{C}$ until dryness. Dipping the TLC plates in a ninhydrin stain and heating them with a heat-gun until dryness or an iodine chamber could be used as well for visualisation of the samples. Flash column chromatography was conducted with silica gel 60 (40-63 $\mu \mathrm{m}$ ) from MACHEREY-NAGEL and solvents for column chromatography were distilled prior to use. Nuclear magnetic resonance (NMR) spectra were recorded either on a Varian Mercury 300, Varian VNMRS 400, Varian VNMRS 600, Bruker Avance Neo 400 or Bruker Avance Neo 600 at $25^{\circ} \mathrm{C}$, if not otherwise stated and were processed and analysed with the program MestReNova. ${ }^{[1]}$ The chemical shifts $\delta$ are given in parts per million (ppm) relative to the residual solvent peak of the non-deuterated solvent $\left(\mathrm{CHCl}_{3}:{ }^{1} \mathrm{H}\right.$ NMR: $\delta=7.26 \mathrm{ppm},{ }^{13} \mathrm{C}\left\{{ }^{1} \mathrm{H}\right\} N M R: \mathrm{CDCl}_{3}: \delta=77.16 \mathrm{ppm}$; Toluene- $d_{8}:{ }^{1} \mathrm{H}$ NMR: $\delta=2.08,6.97,7.01,7.09 \mathrm{ppm},{ }^{13} \mathrm{C}\left\{{ }^{1} \mathrm{H}\right\} N M R$ : Toluene- $\left.d_{8}: \delta=20.43,125.13,127.96,128.87,137.48 \mathrm{ppm}\right) .{ }^{[2]}$ Carbon spectra were measured broad band decoupled. The multiplicity was reported with the following abbreviations: $\mathrm{s}=$ singlet, $\mathrm{d}=$ doublet, $\mathrm{t}=$ triplet, $\mathrm{q}=$ quartet, $\mathrm{m}=$ multiplet, $\mathrm{br}=$ broad signal and combinations thereof. Coupling constants $(J)$ were given in Hertz $(\mathrm{Hz})$. Infrared spectra (IR) were recorded as transmission spectra on a PerkinElmer Spectrum 100 spectrometer using the attenuated total reflectance (ATR) technique. The wavenumbers $v$ of the absorption peaks are listed in $\mathrm{cm}^{-1}$. Mass spectra were recorded on a Finnigan SSQ 7000 spectrometer [electron ionization (El), $70 \mathrm{eV}$; chemical ionization (Cl), methane, $100 \mathrm{eV}$ ] and the resulting signals are given according to their $\mathrm{m} / \mathrm{z}$ values and their relative intensity is reported in parentheses. For high resolution mass spectra (HRMS) a Thermo Fisher Scientific LTQ Orbitrap XL spectrometer [electrospray ionization (ESI) in positive ion mode] was used. For powder X-ray diffraction (PXRD) analysis a Bruker D2 PHASER X-ray diffractometer with Copper- $\mathrm{K}_{\alpha}$ radiation $(\lambda=1.54056 \AA$ ) was used and the PXRD pattern were recorded in a $2 \theta$ range of $15^{\circ}$ to $70^{\circ}$. Data files for calculated PXRD patterns were downloaded from The Cambridge Crystallographic Data Centre (CCDC) database. CCDC codes for Covellite (1626445), Bornite (1591922), Vanadinite (1707631). ${ }^{[3]}$

Mechanochemical reactions were carried out in a RETSCH MM400 mixer mill or in a FRITSCH planetary micro mill model "Pulverisette 7 premium line". If not stated otherwise milling vessels and balls were always of the same material. Specifically, the zirconium oxide of the vessels and balls used for reactions conducted in the mixer mill RETSCH MM400 is yttrium oxide stabilized $\left(\mathrm{ZrO}_{2}-\mathrm{Y}\right)$ while the one for the planetary mill FRITSCH "Pulverisette 7 premium line" is magnesium oxide stabilized $\left(\mathrm{ZrO}_{2}-\mathrm{Mg}\right)$. In the cases mechanochemical reactions had to be conducted under an inert atmosphere, the jars were closed inside a MBraun Labmaster 130 glove box operating under an argon atmosphere. 


\section{Mineral processing}

Covellite and bornite lumps were hammered into pieces of ca. 3 to $8 \mathrm{~mm}$. Then, the samples were milled for 5 min at a milling amplitude of $1.5 \mathrm{~mm}$ in a Fritsch Pulverisette 0 Vibratory Micro Mill equipped with agate mortar and one $70 \mathrm{~mm} \varnothing$ ball of the same material. The mortar and the ball were washed with $1 \mathrm{M} \mathrm{HCl}$, deionized water and later oven dried for $1 \mathrm{~h}$ prior each use in order to avoid samples contamination from previous grindings. The obtained powder was transferred into a glass vial and used for elemental analysis and catalytic tests.

The vanadinite samples have been directly use for elemental analysis or catalytic tests as provided by the Mineral Processing Unit (AMR) RWTH Aachen University.

\section{Synthesis of substrates 1a-f}

\section{$N$-Allyl-N-benzylamine (S1a)}

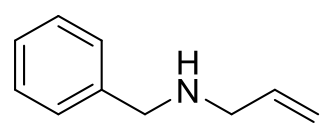

A round bottom flask equipped with a magnetic stirring bar was charged with benzaldehyde ( $5.3076 \mathrm{~g}, 50.02 \mathrm{mmol}, 1.00$ equiv which was filtered over a short plug of

$\mathrm{Na}_{2} \mathrm{CO}_{3}$ prior to use to remove benzoic acid. It was dissolved in $100 \mathrm{~mL}$ DCM and allylamine (3.76 mL, $\rho=0.76 \mathrm{~g} \cdot \mathrm{mL}^{-1}, 50.05 \mathrm{mmol}, 1.00$ equiv) and $\mathrm{MgSO}_{4}(6.0210 \mathrm{~g}, 50.02 \mathrm{mmol}, 1.00$ equiv) were added. The reaction mixture was stirred at room temperature for $27 \mathrm{~h}$. After that time, reaction mixture was filtered over Celite and the solvent was evaporated to yield the crude imine as a yellow oil, which was dissolved in 200 $\mathrm{mL}$ of $\mathrm{MeOH}$ and was cooled in an ice bath. Then, $\mathrm{NaBH}_{4}(2.8388 \mathrm{~g}, 75.04 \mathrm{mmol}, 1.50$ equiv) was added in small portions to the ice-cooled reaction mixture. After the addition of $\mathrm{NaBH}_{4}$ was completed the reaction mixture was allowed to warm up to room temperature overnight. The next day the solvent was evaporated, and the residue was dissolved and partitioned between $150 \mathrm{~mL}$ of $\mathrm{H}_{2} \mathrm{O}$ and $75 \mathrm{~mL}$ EtOAc. After phase separation, the aqueous phase was extracted three times with EtOAc $(75 \mathrm{~mL})$, the organic phases were combined, dried over $\mathrm{Na}_{2} \mathrm{SO}_{4}$ and the solvent was evaporated. The product S1a was purified by column chromatography $\left(\mathrm{SiO}_{2} /\right.$ acetone) to yield a slightly yellow oil (6.2966 g, $42.77 \mathrm{mmol}, 86 \%)$.

$\mathbf{R}_{\mathbf{f}}=0.63$ (acetone), UV-active $(254 \mathrm{~nm})$, stains with $\mathrm{I}_{2}$.

${ }^{1} \mathrm{H}$ NMR (400 MHz, $\mathrm{CDCl}_{3}$ ): $\delta=7.37-7.21(\mathrm{~m}, 5 \mathrm{H}, \mathrm{Ar}-\mathrm{H}), 5.94\left(\mathrm{ddt},{ }^{3} \int_{\mathrm{H}, \mathrm{H}}=17.3,10.3,6.0 \mathrm{~Hz}, 1 \mathrm{H}, \mathrm{RCH}=\mathrm{CH}_{2}\right), 5.20$ $\left(\mathrm{dq},{ }^{3} \mathrm{~J}_{\mathrm{H}, \mathrm{H}}=17.1,1.6 \mathrm{~Hz}, 1 \mathrm{H}, \mathrm{RCH}=\mathrm{CH}_{\mathrm{A}} \mathrm{H}_{\mathrm{B}}\right), 5.12\left(\mathrm{dq},{ }^{3} \mathrm{~J}_{\mathrm{H}, \mathrm{H}}=10.3,1.4 \mathrm{~Hz}, 1 \mathrm{H}, \mathrm{RCH}=\mathrm{CH}_{\mathrm{A}} H_{\mathrm{B}}\right), 3.80(\mathrm{~s}, 2 \mathrm{H}, \mathrm{PhCH} \mathrm{NHR}$ ), $3.28\left(\mathrm{dt},{ }^{3} J_{\mathrm{H}, \mathrm{H}}=6.0,1.5 \mathrm{~Hz}, 2 \mathrm{H}, \mathrm{RNHCH}_{2} \mathrm{CH}=\mathrm{CH}_{2}\right), 1.45(\mathrm{br} \mathrm{s}, 1 \mathrm{H}, \mathrm{NH}) \mathrm{ppm}$.

${ }^{13} \mathrm{C}\left\{{ }^{1} \mathrm{H}\right\}$ NMR (101 MHz, $\left.\mathrm{CDCl}_{3}\right): \delta=140.4,136.9,128.5,128.3,127.1,116.1,53.4,51.9 \mathrm{ppm}$.

IR (ATR): $v=3855,3653,3315,3071,3027,2913,2811,2331,2088,1993,1870,1738,1641,1601,1492,1451$, $1357,1243,1201,1106,1028,992,916,820,734,698 \mathrm{~cm}^{-1}$.

MS (100 eV, Cl): $m / z(\%): 148(28)[M+H]^{+}$.

MS (70 eV, EI): m/z (\%): $147(25)[M]^{+}, 146(72)[\mathrm{M}-\mathrm{H}]^{+}, 120(11), 91(100)\left[\mathrm{C}_{7} \mathrm{H}_{7}\right]^{+}$.

The NMR data closely match the ones previously reported in the literature. ${ }^{[4]}$ 


\section{N-Allyl-N-benzyl-2-bromo-2-methylpropanamide (1a)}

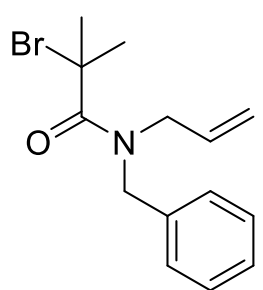

Secondary amine S1a (6.0000 g, $40.76 \mathrm{mmol}, 1.00$ equiv) was dissolved in $250 \mathrm{~mL}$ of distilled $\mathrm{Et}_{2} \mathrm{O}$ and cooled in an ice bath before $\mathrm{NEt}_{3}\left(11.3 \mathrm{~mL}, \rho=0.728 \mathrm{~g} \cdot \mathrm{mL}^{-1}, 81.30 \mathrm{mmol}, 2.00\right.$ equiv) was added. Then, to the cooled solution of $\mathbf{S 1 a}, \alpha$-bromoisobutyryl bromide $(5.0 \mathrm{~mL}, \rho=1.86$ $\mathrm{g} \cdot \mathrm{mL}^{-1}, 40.45 \mathrm{mmol}, 1.00$ equiv) was added dropwise and a white precipitate formed immediately. The resulting reaction mixture was allowed to warm up to room temperature overnight. The next day the reaction was stopped by adding $50 \mathrm{~mL}$ of an aqueous saturated $\mathrm{NH}_{4} \mathrm{Cl}$ solution and the biphasic reaction mixture was vigorously stirred for $5 \mathrm{~min}$. It was concentrated under reduced pressure and the residue was partitioned between $100 \mathrm{~mL}$ distilled $\mathrm{Et}_{2} \mathrm{O}$ and $100 \mathrm{~mL}$ of an aqueous saturated $\mathrm{NaHCO}_{3}$ solution. After phase separation, the aqueous phase was extracted three times with distilled $\mathrm{Et}_{2} \mathrm{O}(100 \mathrm{~mL})$, the organic phases were combined and dried over $\mathrm{Na}_{2} \mathrm{SO}_{4}$. The solvent was evaporated to yield the title compound 1a as a slightly yellow oil $(11.2942 \mathrm{~g}, 38.13 \mathrm{mmol}, 94 \%)$ after column chromatography $\left(\mathrm{SiO}_{2} / n\right.$ pentane:EtOAc 4:1 v/v).

$\boldsymbol{R}_{\mathrm{f}}=0.84$ ( $n$-pentane:EtOAc 1:1 $\left.\mathrm{v} / \mathrm{v}\right)$, UV-active, stains with $\mathrm{KMnO}_{4}$.

${ }^{1} \mathrm{H}$ NMR (400 MHz, Toluene- $\left.\boldsymbol{d}_{8}, 9^{\circ}{ }^{\circ} \mathrm{C}\right): \delta=7.19-6.93(\mathrm{~m}, 5 \mathrm{H}, \mathrm{Ar}-\mathrm{H}), 5.51-5.70\left(\mathrm{~m}, 1 \mathrm{H}, \mathrm{RCH}=\mathrm{CH}_{2}\right), 4.90-5.05(\mathrm{~m}$, $\left.2 \mathrm{H}, \mathrm{RCH}=\mathrm{CH}_{2}\right), 4.65\left(\mathrm{~s}, 2 \mathrm{H}, \mathrm{NCH}_{2} \mathrm{Ph}\right), 4.00\left(\mathrm{~s}, 2 \mathrm{H}, \mathrm{NCH}_{2}\right), 1.82\left(\mathrm{~s}, 6 \mathrm{H}, 2 \times \mathrm{CH}_{3}\right) \mathrm{ppm}$.

${ }^{13} \mathrm{C}\left\{{ }^{1} \mathrm{H}\right\}$ NMR $\left(101 \mathrm{MHz}\right.$, Toluene- $\left.d_{8}, 95^{\circ} \mathrm{C}\right): \delta=170.3,137.6,133.8,128.9,128.0,127.5,117.4,57.9,50.7,50.4$, $33.2 \mathrm{ppm}$.

IR (ATR): $v=3261,3066,3012,2980,2930,2662,2334,2195,2098,1950,1635,1494,1460,1411,1364,1285$, $1247,1169,1108,1026,996,927,808,730,698 \mathrm{~cm}^{-1}$.

MS (100 eV, Cl): $m / z(\%): 296(91)[M+H]^{+}$.

MS (70 eV, El): $m / z(\%): 296(12)[M+H]^{+}, 216(100), 91(43)\left[C_{7} \mathrm{H}_{7}\right]^{+}$.

The NMR data closely match the ones previously reported in the literature. ${ }^{[5]}$

\section{$\mathrm{N}$-Allyl-2-bromo-N-2-dimethylpropanamide (1b)}

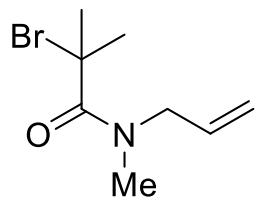

$\mathrm{N}$-Allylmethylamine $\left(0.9950 \mathrm{~g}, 13.99 \mathrm{mmol}, 1.00\right.$ equiv) was dissolved in $50 \mathrm{~mL}$ distilled $\mathrm{Et}_{2} \mathrm{O}$, followed by addition of $\mathrm{NEt}_{3}\left(3.9 \mathrm{~mL}, \rho=0.728 \mathrm{~g} \cdot \mathrm{mL}^{-1}, 28.14 \mathrm{mmol}, 2.01\right.$ equiv). The reaction mixture was cooled in an ice bath. Then, $\alpha$-bromoisobutyryl bromide $\left(1.74 \mathrm{~mL}, \rho=1.86 \mathrm{~g} \cdot \mathrm{mL}^{-}\right.$

$1,14.07 \mathrm{mmol}, 1.01$ equiv) was added. A white precipitate formed immediately upon addition. The reaction mixture was stirred overnight allowed to warm up to room temperature. The next day, the reaction was stopped by adding $40 \mathrm{~mL}$ of an aqueous saturated $\mathrm{NH}_{4} \mathrm{Cl}$ solution. The biphasic reaction mixture was stirred for $5 \mathrm{~min}$ and was then partitioned between an aqueous saturated $\mathrm{NaHCO}_{3}$ solution $\left(50 \mathrm{~mL}\right.$ ) and distilled $\mathrm{Et}_{2} \mathrm{O}$ $(75 \mathrm{~mL})$. After separating the phases, the aqueous phase was extracted three times with distilled $\mathrm{Et}_{2} \mathrm{O}(75 \mathrm{~mL})$, the organic phases were combined and dried over $\mathrm{Na}_{2} \mathrm{SO}_{4}$. The solvent was evaporated to yield the title compound $\mathbf{1 b}$ as a colorless oil $(2.5796 \mathrm{~g}, 11.71 \mathrm{mmol}, 84 \%)$ after column chromatography $\left(\mathrm{SiO}_{2} / \mathrm{n}\right.$ pentane:EtOAc 4:1 v/v). 
$\boldsymbol{R}_{\mathrm{f}}=0.37$ ( $n$-pentane:EtOAc 4:1 v/v), UV-active, stains with $\mathrm{KMnO}_{4}$

${ }^{1} \mathrm{H}$ NMR $\left(400 \mathrm{MHz}\right.$, Toluene- $\left.d_{8}, 95^{\circ} \mathrm{C}\right): \delta=5.52-5.61\left(\mathrm{~m}, 1 \mathrm{H}, \mathrm{RCH}=\mathrm{CH}_{2}\right), 4.94-4.96\left(\mathrm{~m}, 1 \mathrm{H}, \mathrm{RCH}=\mathrm{CH}_{\mathrm{A}} \mathrm{H}_{\mathrm{B}}\right), 4.91-$ $4.93\left(\mathrm{~m}, 1 \mathrm{H}, \mathrm{RCH}=\mathrm{CH}_{\mathrm{A}} \mathrm{H}_{\mathrm{B}}\right), 3.88\left(\mathrm{~d},{ }^{3} \mathrm{~J}_{\mathrm{H}, \mathrm{H}}=5.8 \mathrm{~Hz}, 2 \mathrm{H}, \mathrm{CH}_{2}\right), 2.82\left(\mathrm{~s}, 3 \mathrm{H}, \mathrm{NCH}_{3}\right), 1.78\left(\mathrm{~s}, 6 \mathrm{H}, 2 \times \mathrm{CH}_{3}\right) \mathrm{ppm}$.

${ }^{13} \mathrm{C}\left\{{ }^{1} \mathrm{H}\right\}$ NMR $\left(101 \mathrm{MHz}\right.$, Toluene- $\left.d_{8}, 95^{\circ} \mathrm{C}\right): \delta=169.9,133.9,116.9,57.7,53.4,36.4,33.0 \mathrm{ppm}$.

IR (ATR): $v=3260,3082,2978,2929,2161,2017,1632,1467,1426,1395,1371,1280,1178,1087,988,923,756$ $\mathrm{cm}^{-1}$.

MS (100 eV, Cl): $m / z(\%): 220(59)[M+H]^{+}$.

MS (70 eV, EI): m/z (\%): 220 (30) [M+H] $, 219(100)[M]^{+}, 140$ (100), 112 (24), 98 (58), 70 (21).

HRMS (ESI): $m / z$ calculated for $\mathrm{C}_{8} \mathrm{H}_{14} \mathrm{BrNO} \mathrm{Na}^{+}: 242.0151[\mathrm{M}+\mathrm{Na}]^{+}$; found: 242.0152.

\section{N-Allyl-4-methylbenzenesulfonamide (S1C)}<smiles>C=CCNS(=O)(=O)c1ccc(C)cc1</smiles>

A round bottom flask equipped with a magnetic stirring bar was charged with allylamine ( $1.97 \mathrm{~mL}, \rho=0.76 \mathrm{~g} \cdot \mathrm{mL}^{-1}, 26.27 \mathrm{mmol}, 3.00$ equiv) and dissolved in $44 \mathrm{~mL}$ of DCM. To this solution, 4-toluenesulfonyl chloride $(1.67 \mathrm{~g}, 8.76 \mathrm{mmol}, 1.00$ equiv) dissolved in $6 \mathrm{~mL}$ of DCM was added dropwise. The reaction mixture was stirred at room temperature for $12 \mathrm{~h}$. After that time, $50 \mathrm{~mL}$ of $\mathrm{H}_{2} \mathrm{O}$ were added, and the aqueous phase extracted three times with DCM $(20 \mathrm{~mL})$. The combined organic fractions were dried over $\mathrm{MgSO}_{4}$ and the solvent was removed under reduced pressure. The product S1c was obtained as a light yellow solid $(1.70 \mathrm{~g}, 8.05 \mathrm{mmol}, 92 \%)$. The product was considered pure enough for the next step and no further purification was needed.

m.p.: $60.5-60.9^{\circ} \mathrm{C}$.

${ }^{1} \mathrm{H}$ NMR $\left(600 \mathrm{MHz}, \mathrm{CDCl}_{3}\right): \delta=7.70-7.80(\mathrm{~m}, 2 \mathrm{H}, \mathrm{Ar}-H), 7.25-7.35(\mathrm{~m}, 2 \mathrm{H}, \mathrm{Ar}-H), 5.65-5.75\left(\mathrm{~m}, 1 \mathrm{H}, \mathrm{RCH}=\mathrm{CH}_{2}\right)$, $5.16\left(\mathrm{~d}, 3^{3} \mathrm{H}_{\mathrm{H}}=17.3 \mathrm{~Hz}, 1 \mathrm{H}, \mathrm{RCH}=\mathrm{CH}_{\mathrm{A}} \mathrm{H}_{\mathrm{B}}\right), 5.08\left(\mathrm{~d},{ }^{3} \mathrm{~J}_{\mathrm{H}, \mathrm{H}}=9.9 \mathrm{~Hz}, 1 \mathrm{H}, \mathrm{RCH}=\mathrm{CH}_{\mathrm{A}} H_{\mathrm{B}}\right), 4.65-4.85(\mathrm{br} \mathrm{s}, 1 \mathrm{H}, \mathrm{NH}), 3.55-$ $3.60\left(\mathrm{~m}, 2 \mathrm{H}, \mathrm{CH}_{2}\right), 2.42\left(\mathrm{~s}, 3 \mathrm{H}, \mathrm{Ar}-\mathrm{CH}_{3}\right) \mathrm{ppm}$;

${ }^{13} \mathrm{C}\left\{{ }^{1} \mathrm{H}\right\}$ NMR (151 MHz, $\left.\mathrm{CDCl}_{3}\right): \delta=143.6,137.1,133.1,129.8,127.3,117.8,45.9,21.6 \mathrm{ppm}$.

IR (ATR): $v=3247,2928,2855,1649,1594,1493,1422,1317,1155,1092,1062,994,933,873,809,663 \mathrm{~cm}^{-1}$.

MS (EI, 70 eV): m/z (\%): $212(5)[M+H]^{+}, 211(13)[M]^{+}, 155$ (36), $157(25), 92(27), 91(100)\left[C_{7} \mathrm{H}_{7}\right]^{+}, 66(27), 59$ (38).

The NMR data closely match the ones previously reported in the literature. ${ }^{[6]}$ 


\section{N-Allyl-2-bromo-2-methyl-N-tosylpropanamide (1c)}

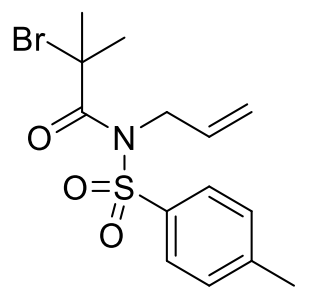

$N$-Allyl-4-methylbenzenesulfonamide S1c (1.0 g, $4.733 \mathrm{mmol}, 1.00$ equiv) was dissolved in $24 \mathrm{~mL}$ of distilled $\mathrm{Et}_{2} \mathrm{O}$, the solution cooled with an ice bath and $\mathrm{NEt}_{3}(1.3 \mathrm{~mL}, \rho=0.728$ $\mathrm{g} \cdot \mathrm{mL}^{-1}, 9.47 \mathrm{mmol}, 2.00$ equiv) was added dropwise. The reaction mixture was stirred at the same temperature for $3 \mathrm{~h}$. Then, $\alpha$-bromoisobutyryl bromide $\left(0.6 \mathrm{~mL}, \rho=1.86 \mathrm{~g} \cdot \mathrm{mL}^{-1}\right.$, $4.73 \mathrm{mmol}, 1.00$ equiv) was added dropwise with the help of a syringe pump (40 drops/min). The solution was allowed to warm up to room temperature and stirred for additional $24 \mathrm{~h}$. After this time, the reaction was stopped by adding $10 \mathrm{~mL}$ of an aqueous saturated $\mathrm{NH}_{4} \mathrm{Cl}$ solution. The biphasic reaction mixture was stirred for additional $5 \mathrm{~min}$, then $10 \mathrm{~mL}$ of an aqueous saturated $\mathrm{NaHCO}_{3}$ solution were added and the aqueous phase was extracted three times with distilled $\mathrm{Et}_{2} \mathrm{O}(10 \mathrm{~mL})$. The organic phases were combined and dried over $\mathrm{MgSO}_{4}$. The solvent was evaporated to yield the title compound 1c as a yellowish powder $\left(0.6243 \mathrm{mg}, 1.73 \mathrm{mmol}, 37 \%\right.$ yield) after column chromatography $\left(\mathrm{SiO}_{2} / \mathrm{n}-\right.$ pentane:EtOAc 3:1 v/v).

$\boldsymbol{R}_{\mathrm{f}}=0.54$ ( $n$-pentane:EtOAc 2:1 $\mathrm{V} / \mathrm{V}$ ), UV-active, stains with $\mathrm{KMnO}_{4}$.

m.p.: $79.6-80.4^{\circ} \mathrm{C}$.

${ }^{1} \mathrm{H}$ NMR $\left(600 \mathrm{MHz}, \mathrm{CDCl}_{3}\right): \delta=7.80-7.90(\mathrm{~m}, 2 \mathrm{H}, \mathrm{Ar}-\mathrm{H}), 7.25-7.35(\mathrm{~m}, 2 \mathrm{H}, \mathrm{Ar}-\mathrm{H}), 5.95-6.05\left(\mathrm{~m}, 1 \mathrm{H}, \mathrm{RCH}=\mathrm{CH}_{2}\right)$, $5.41\left(\mathrm{~d},{ }^{3} \mathrm{~J}_{\mathrm{H}, \mathrm{H}}=17.1 \mathrm{~Hz}, 1 \mathrm{H}, \mathrm{RCH}=\mathrm{CH}_{\mathrm{A}} \mathrm{H}_{\mathrm{B}}\right), 5.34\left(\mathrm{~d},{ }^{3} \mathrm{~J}_{\mathrm{H}, \mathrm{H}}=10.6 \mathrm{~Hz}, 1 \mathrm{H}, \mathrm{RCH}=\mathrm{CH}_{\mathrm{A}} H_{\mathrm{B}}\right), 4.90-5.00\left(\mathrm{~m}, 2 \mathrm{H}, \mathrm{CH}_{2}\right), 2.43(\mathrm{~s}$, $\left.3 \mathrm{H}, \mathrm{Ar}-\mathrm{CH}_{3}\right), 1.88\left(\mathrm{~s}, 6 \mathrm{H}, 2 \times \mathrm{CH}_{3}\right) \mathrm{ppm}$.

${ }^{13} \mathrm{C}\left\{{ }^{1} \mathrm{H}\right\}$ NMR $\left(151 \mathrm{MHz}, \mathrm{CDCl}_{3}\right): \delta=170.5,144.8,136.3,133.7,129.3,129.0,118.3,57.2,50.7,32.2,21.8 \mathrm{ppm}$.

IR (ATR): $v=3336,2988,2927,2166,1674,1593,1460,1348,1315,1460,1438,1315,1236,1160,1090,1051$, $925,805,773,716 \mathrm{~cm}^{-1}$.

MS (EI, 70 eV): m/z (\%): $362(1)[M+H]^{+}, 361(1)[M]^{+}, 359(1)[M]^{+}, 190(100), 198(98), 91(78)\left[C_{7} \mathrm{H}_{7}\right]^{+}, 47(40)$.

HRMS: calculated for $\mathrm{C}_{14} \mathrm{H}_{18} \mathrm{BrNO}_{3} \mathrm{~S}+\mathrm{Na}^{+}$: $382.0091[\mathrm{M}+\mathrm{Na}]^{+}$; found: 382.0083.

\section{$N-(2-M e t h a l l y l)$ benzylamine (S1d)}

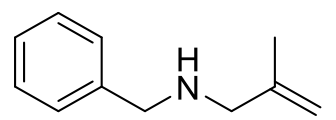

A round bottom flask equipped with a magnetic stirring bar was charged with benzylamine (1.0737 g, $10.02 \mathrm{mmol}, 1.00$ equiv), which was dissolved in $100 \mathrm{~mL} \mathrm{MeCN} . \mathrm{K}_{2} \mathrm{CO}_{3}$ (2.7656 g, $20.01 \mathrm{mmol}, 2.00$ equiv), $\mathrm{Nal}(0.1500 \mathrm{~g}, 1.00 \mathrm{mmol}, 0.10$ equiv) and 3-chloro-2-methyl1-propene ( $1.0 \mathrm{~mL}, \rho=0.92 \mathrm{~g} \cdot \mathrm{mL}^{-1}, 9.96 \mathrm{mmol}, 0.99$ equiv) were added at room temperature in the given order. The reaction mixture was refluxed in an oil bath for $32 \mathrm{~h}$ and then cooled to room temperature. $\mathrm{H}_{2} \mathrm{O}(100 \mathrm{~mL})$ was added and the volatiles were removed under reduced pressure. The aqueous phase was extracted three times EtOAc $(100 \mathrm{~mL})$, the organic phases were combined, dried over $\mathrm{MgSO}_{4}$, and the solvent was removed under reduced pressure. The crude secondary amine was purified by column chromatography $\left(\mathrm{SiO}_{2} / \mathrm{n}\right.$-pentane:EtOAc $19: 1 \rightarrow 4: 1 \mathrm{v} / \mathrm{v}$ ) to yield the title compound $\mathbf{S 1 d}$ as a yellow oil $(0.5289 \mathrm{~g}, 3.28 \mathrm{mmol}, 33 \%)$. 
$\mathbf{R}_{\mathbf{f}}=0.16(n$-Pentane:EtOAc 4:1 $\mathrm{v} / \mathrm{v})$, UV-active $(254 \mathrm{~nm})$, stains with $\mathrm{I}_{2}$.

${ }^{1} \mathrm{H}$ NMR (400 MHz, $\left.\mathrm{CDCl}_{3}\right): \delta=7.40-7.19(\mathrm{~m}, 5 \mathrm{H}, \mathrm{Ar}-\mathrm{H}), 4.92\left(\mathrm{~s}, 1 \mathrm{H}, \mathrm{R}=\mathrm{CH}_{\mathrm{A}} \mathrm{H}_{\mathrm{B}}\right), 4.87\left(\mathrm{~s}, 1 \mathrm{H}, \mathrm{R}=\mathrm{CH}_{\mathrm{A}} H_{\mathrm{B}}\right), 3.78(\mathrm{~s}, 2 \mathrm{H}$, $\left.\mathrm{RCH}_{2} \mathrm{~N}\right), 3.21\left(\mathrm{~s}, 2 \mathrm{H}, \mathrm{PhCH}_{2} \mathrm{~N}\right), 1.78\left(\mathrm{~s}, 3 \mathrm{H}, \mathrm{CH}_{3}\right), 1.57(\mathrm{br} \mathrm{s}, 1 \mathrm{H}, \mathrm{NH}) \mathrm{ppm}$.

${ }^{13} \mathrm{C}\left\{{ }^{1} \mathrm{H}\right\}$ NMR (101 MHz, $\left.\mathrm{CDCl}_{3}\right): \delta=144.0,140.6,128.5,128.3,127.0,110.9,55.1,53.2,20.9 \mathrm{ppm}$.

IR (ATR): $v=3868,3651,3329,3071,3029,2971,2910,2817,2332,2097,1944,1873,1801,1651,1449,1364$, $1235,1200,1114,1027,971,893,822,734,699 \mathrm{~cm}^{-1}$.

MS (100 eV, Cl): $m / z(\%): 162(100)[M+H]^{+}$.

MS (70 eV, El): $m / z$ (\%): $161(21)[M]^{+}, 120$ (17), 106 (9), $91(43)\left[\mathrm{C}_{7} \mathrm{H}_{7}\right]^{+}$.

The NMR data closely match the ones previously reported in the literature. ${ }^{[4]}$

\section{$N$-Benzyl-2-bromo-2-methyl-N-(2-methylallyl)propanamide (1d)}

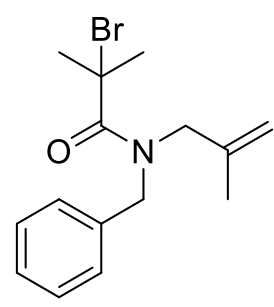

A round bottom flask equipped with a magnetic stirring bar was charged with secondary amine S1b (0.4435 g, $2.75 \mathrm{mmol}, 1.00$ equiv), which was dissolved in $25 \mathrm{~mL}$ of distilled $\mathrm{Et}_{2} \mathrm{O}$. $\mathrm{NEt}_{3}\left(0.76 \mathrm{~mL}, \rho=0.73 \mathrm{~g} \cdot \mathrm{mL}^{-1}, 5.48 \mathrm{mmol}, 1.99\right.$ equiv) was added to the solution and the reaction mixture was cooled in an ice bath. $\alpha$-Bromoisobutyryl bromide $(0.34 \mathrm{~mL}, \rho=1.86$ $\mathrm{g} \cdot \mathrm{mL}^{-1}, 2.75 \mathrm{mmol}, 1.00$ equiv) was added slowly and a white precipitate formed immediately upon addition. The reaction mixture was allowed to warm up to room temperature and stirred overnight. The next day, $20 \mathrm{~mL}$ of an aqueous saturated $\mathrm{NH}_{4} \mathrm{Cl}$ solution were added to stop the reaction. The biphasic reaction mixture was vigorously stirred for $15 \mathrm{~min}$ and then partitioned between $30 \mathrm{~mL}$ of an aqueous saturated $\mathrm{NaHCO}_{3}$ solution and $25 \mathrm{~mL}$ of distilled $\mathrm{Et}_{2} \mathrm{O}$. After phase separation, the aqueous phase was extracted three times with distilled $\mathrm{Et}_{2} \mathrm{O}(30 \mathrm{~mL})$, the organic phases were combined, dried over $\mathrm{Na}_{2} \mathrm{SO}_{4}$ and the solvent removed under reduced pressure. The crude amide was purified by column chromatography $\left(\mathrm{SiO}_{2} / n\right.$ pentane:EtOAc 19:1 $\mathrm{v} / \mathrm{v}$ ) to yield the title compound $1 \mathbf{d}$ as a yellow oil $(0.7163 \mathrm{~g}, 2.31 \mathrm{mmol}, 84 \%)$.

$\mathbf{R}_{\mathbf{f}}=0.63$ ( $n$-pentane:EtOAc 9:1 v/v), UV-active (254 nm).

${ }^{1} \mathrm{H}$ NMR $\left(600 \mathrm{MHz}\right.$, Toluene- $\left.d_{8}, 95^{\circ} \mathrm{C}\right): \delta=7.14-6.93(\mathrm{~m}, 5 \mathrm{H}, \mathrm{Ar}-\mathrm{H}), 4.78\left(\mathrm{~s}, 1 \mathrm{H}, \mathrm{R}=\mathrm{CH}_{\mathrm{A}} \mathrm{H}_{\mathrm{B}}\right), 4.70\left(\mathrm{~s}, 2 \mathrm{H}, \mathrm{PhCH} \mathrm{N}_{2} \mathrm{~N}\right)$, $4.68\left(\mathrm{~s}, 1 \mathrm{H}, \mathrm{R}=\mathrm{CH}_{\mathrm{A}} \mathrm{H}_{\mathrm{B}}\right), 4.01\left(\mathrm{~s}, 2 \mathrm{H}, \mathrm{NCH}_{2}\right), 1.83\left(\mathrm{~s}, 6 \mathrm{H}, 2 \times \mathrm{CH}_{3}\right), 1.51\left(\mathrm{~s}, 3 \mathrm{H}, \mathrm{CH}_{2} \mathrm{CH}_{3}=\mathrm{CH}_{2}\right) \mathrm{ppm}$.

${ }^{13} \mathrm{C}\left\{{ }^{1} \mathrm{H}\right\}$ NMR (151 MHz, Toluene- $\left.d_{8}, 95{ }^{\circ} \mathrm{C}\right): \delta=170.6,141.1,138.1,128.9,128.0,127.6,112.4,58.2,53.0,51.2$, 33.4, $20.0 \mathrm{ppm}$.

IR (ATR): $v=3264,3068,2976,2931,2327,2094,1994,1882,1637,1494,1457,1414,1369,1290,1247,1168$, $1108,1079,1053,1029,1001,939,896,819,731,698 \mathrm{~cm}^{-1}$.

MS (100 eV, Cl): $m / z(\%): 310(4)[M+H]^{+}$.

MS (70 eV, El): m/z (\%): $310(14)[M+H]^{+}, 309(20)[M]^{+}, 230(100), 160(15), 91(46)\left[\mathrm{C}_{7} \mathrm{H}_{7}\right]^{+}$.

HRMS (ESI): $m / z$ calculated for $\mathrm{C}_{15} \mathrm{H}_{20} \mathrm{BrNO}+\mathrm{Na}^{+}: 332.0621$ [M+Na] $]^{+}$; found: 332.0621 . 


\section{$N$-Benzyl-2-bromo-N-(hexa-2,4-dien-1-yl)-2-methylpropanamide (1e)}

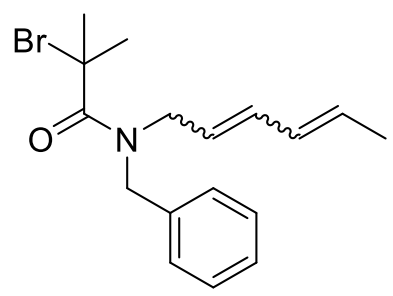

A round bottom flask equipped with a magnetic stirring bar was charged with benzylamine ( $3.1 \mathrm{~mL}, \rho=0.98 \mathrm{~g} \cdot \mathrm{mL}^{-1}, 28.00 \mathrm{mmol}, 1.00$ equiv) and dissolved in $24 \mathrm{~mL}$ of $\mathrm{MeOH}$. To this solution, 2,4-hexadienal $\left(3.0 \mathrm{~mL}, \rho=0.90 \mathrm{~g} \cdot \mathrm{mL}^{-1}, 28.00 \mathrm{mmol}, 1.00\right.$ equiv) was added and the solution stirred for $2 \mathrm{~h}$ at room temperature. The mixture was then cooled with an ice bath for 30 minutes, $\mathrm{NaBH}_{4}(2.12 \mathrm{~g}, 55.99 \mathrm{mmol}, 2.00$ equiv) added and the solution stirred for another hour. After this time, $20 \mathrm{~mL}$ of $\mathrm{H}_{2} \mathrm{O}$ were added, and the aqueous phase was extracted two times with DCM (15 mL). The combined organic fractions were washed with an aqueous $20 \% \mathrm{NaOH}$ solution $(10 \mathrm{~mL})$, an aqueous saturated $\mathrm{NaCl}$ solution $(10 \mathrm{~mL})$, dried over $\mathrm{MgSO}_{4}$ and the solvent was removed under reduced pressure. The crude mixture was purified by distillation using a glass oven apparatus $\left(136.0^{\circ} \mathrm{C}, 10 \mathrm{mbar}\right)$ to obtain $\mathrm{N}$-benzylhexa-2,4-dien-1-amine product S1e as a lightyellow oil (4831.6 g, $25.80 \mathrm{mmol}, 95 \%) .{ }^{1} \mathrm{H} \mathrm{NMR}\left(600 \mathrm{MHz}, \mathrm{CDCl}_{3}\right): \delta=7.29-7.36(\mathrm{~m}, 4 \mathrm{H}, \mathrm{Ar}-\mathrm{H}), 7.21-7.29$ (m, $1 \mathrm{H}, \mathrm{Ar}-\mathrm{H}), 6.12-6.20\left(\mathrm{~m}, 1 \mathrm{H}, \mathrm{RCH}=\mathrm{CHR}^{\prime}\right), 6.04-6.11\left(\mathrm{~m}, 1 \mathrm{H}, \mathrm{RCH}=\mathrm{CHR}^{\prime}\right), 5.62-5.70(\mathrm{~m}, 2 \mathrm{H}, 2 \times \mathrm{RCH}=\mathrm{CHR}), 3.79(\mathrm{~s}$, $\left.2 \mathrm{H}, \mathrm{NCH}_{2} \mathrm{Ph}\right), 3.29\left(\mathrm{~d},{ }^{3} \mathrm{H}_{\mathrm{H}, \mathrm{H}}=6.3 \mathrm{~Hz}, 2 \mathrm{H}, \mathrm{NCH}_{2} \mathrm{R}\right), 1.76\left(\mathrm{~d},{ }^{3} \mathrm{~J}_{\mathrm{H}, \mathrm{H}}=6.3 \mathrm{~Hz}, 3 \mathrm{H}, \mathrm{RCH}\right) \mathrm{ppm} ;{ }^{13} \mathrm{C}\left\{{ }^{1} \mathrm{H}\right\} \mathrm{NMR}(151 \mathrm{MHz}$, $\left.\mathrm{CDCl}_{3}\right): \delta=140.5,132.1,131.3,129.3,128.8,128.5,128.3,127.0,53.4,51.0,18.2 \mathrm{ppm}$. The NMR data closely match the ones previously reported in the literature. ${ }^{[7]}$

For the synthesis of product 1e, compound S1e was directly used in the next reaction without any further purification.

A round bottom flask equipped with a magnetic stirring bar was charged with $N$-benzylhexa-2,4-dien-1-amine S1e (1.00 g, $5.34 \mathrm{mmol}, 1.0$ equiv), dissolved in $27 \mathrm{~mL}$ of dry DCM and cooled to with an ice bath, under argon atmosphere. To this solution were added first $\alpha$-bromoisobutyryl bromide $\left(0.7 \mathrm{~mL}, \rho=1.86 \mathrm{~g} \cdot \mathrm{mL}^{-1}, 5.339 \mathrm{mmol}\right.$, 1.0 equiv) all in once and afterward $\mathrm{NEt}_{3}\left(747.3 \mu \mathrm{l}, \rho=0.728 \mathrm{~g} \cdot \mathrm{mL}^{-1}, 5.34 \mathrm{mmol}, 1.0\right.$ equiv) dropwise. The reaction mixture was cooled in an ice bath and stirred for additional $3 \mathrm{~h}$. After this time, the reaction was stopped by adding $10 \mathrm{~mL}$ of an aqueous saturated $\mathrm{NH}_{4} \mathrm{Cl}$ solution. The biphasic reaction mixture was stirred for additional 5 min, then $10 \mathrm{~mL}$ of an aqueous saturated $\mathrm{NaHCO}_{3}$ solution were added and the water phase extracted three times with DCM (15 mL). The organic phases were combined and dried over $\mathrm{MgSO}_{4}$. The solvent was evaporated to yield the title compound $1 \mathrm{e}$ as a yellowish oil (1.496 g, $4.45 \mathrm{mmol}, 83 \%$ yield) after column chromatography $\left(\mathrm{SiO}_{2} / n\right.$-pentane:EtOAc 4:1 v/v).

$\boldsymbol{R}_{\mathbf{f}}=0.80\left(n\right.$-pentane:EtOAc 3:1 v/v), UV-active, stains with $\mathrm{KMnO}_{4}$.

${ }^{1} \mathbf{H}$ NMR (600 MHz, Toluene- $\left.d_{8}, 95{ }^{\circ} \mathrm{C}\right): \delta=6.92-7.19(\mathrm{~m}, 5 \mathrm{H}, \mathrm{Ar}-\mathrm{H}), 5.80-5.99\left(\mathrm{~m}, 2 \mathrm{H}, \mathrm{CH}_{3} \mathrm{CH}=\mathrm{CHR}+\right.$ $\left.\mathrm{NCH}_{2} \mathrm{CH}=\mathrm{CHR}\right), 5.29-5.53\left(\mathrm{~m}, 2 \mathrm{H}, \mathrm{CH}_{3} \mathrm{CH}=\mathrm{CHR}+\mathrm{NCH}_{2} \mathrm{CH}=\mathrm{CHR}\right), 4.68\left(\mathrm{~s}, 2 \mathrm{H}, \mathrm{HCH}_{2} \mathrm{Ph}\right), 4.02-4.12(\mathrm{~m}, 2 \mathrm{H}$, $\left.\mathrm{NCH}_{2} \mathrm{CH}=\mathrm{CHR}\right), 1.80-1.88\left(\mathrm{~m}, 6 \mathrm{H}, 2 \times \mathrm{CH}_{3}\right), 1.53-1.60\left(\mathrm{~m}, 3 \mathrm{H}, \mathrm{CH}=\mathrm{CHCH}_{3}\right) \mathrm{ppm}$.

${ }^{13} \mathrm{C}\left\{{ }^{1} \mathrm{H}\right\}$ NMR (151 MHz, Toluene- $\left.d_{8}, 95^{\circ} \mathrm{C}\right): \delta=170.3,138.2,134.1,131.5,129.4,128.9,128.1,127.5,125.8,58.0$, 50.7, 49.9, 33.3, 17.8. ppm.

The bidimensional spectroscopic techniques carried out at a temperature of $95{ }^{\circ} \mathrm{C}$ in toluene- $d_{8}$ were not sufficient to identify the $E / Z$ configuration of the two double bonds of the compound $1 \mathbf{e}$.

IR (ATR): $v=3020,2975,2929,2327,2090,1635,1494,1458,1414,1361,1249,1166,1107,990,940,728,698$ $\mathrm{cm}^{-1}$. 
MS (100 eV, Cl): m/z (\%): $339(15)[M+H]^{+}, 338(77)[M+H]^{+}$.

MS (El, 70 eV): m/z (\%): 339 (3) [M+H]+, $338(16)[M]^{+}, 336$ (17) [M]+, 256 (100), 91 (71), 81 (32).

HRMS: calculated for $\mathrm{C}_{17} \mathrm{H}_{22} \mathrm{BrNONa}[\mathrm{M}+\mathrm{Na}]^{+}: 358.0785$; found: 358.0777 .

\section{N-Benzyl-N-prenylamine (S1f)}

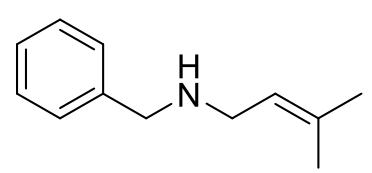

A round bottom flask equipped with a magnetic stirring bar was charged with 3-methyl2-butenal ( $1.0011 \mathrm{~g}, 11.90 \mathrm{mmol}, 1.00$ equiv), which was filtered over $\mathrm{Na}_{2} \mathrm{CO}_{3}$ before use to remove the corresponding carboxylic acid. Then, 3-methyl-2-butenal was dissolved in DCM $(20 \mathrm{~mL})$ and benzylamine $\left(1.3 \mathrm{~mL}, \rho=0.981 \mathrm{~g} \cdot \mathrm{mL}^{-1}, 11.90 \mathrm{mmol}, 1.00\right.$

equiv) as well as $\mathrm{MgSO}_{4}$ (1.4369 g, $11.94 \mathrm{mmol}, 1.00$ equiv) were added. The reaction mixture was stirred for 4 days at room temperature and then filtered over Celite. Next, the solvent was removed under reduced pressure and the crude imine was dissolved in $\mathrm{MeOH}(50 \mathrm{~mL})$ and cooled in an ice bath. $\mathrm{NaBH}_{4}(1.1286 \mathrm{~g}, 29.83 \mathrm{mmol}$, 2.51 equiv) was added in small portions and the reaction mixture was allowed to warm up to room temperature overnight. The next day, the solvent was evaporated and the residue was partitioned between $\mathrm{H}_{2} \mathrm{O}(40 \mathrm{~mL})$ and EtOAc $(40 \mathrm{~mL})$. After phase separation the aqueous phase was extracted three times with EtOAc $(40 \mathrm{~mL})$, the organic phases were combined and dried over $\mathrm{Na}_{2} \mathrm{SO}_{4}$. The solvent was removed, and the crude secondary amine was purified by column chromatography $\left(\mathrm{SiO}_{2} / \mathrm{EtOAc}\right)$ to yield the title compound $\mathbf{S 1 f}$ as a yellow oil (1.2233 $\mathrm{g}$, $6.98 \mathrm{mmol}, 59 \%)$.

$\mathbf{R}_{\mathbf{f}}=0.20$ (EtOAc), smears, UV-active (254 nm), stains with ninhydrin.

${ }^{1} \mathrm{H}$ NMR $\left(400 \mathrm{MHz}, \mathrm{CDCl}_{3}\right): \delta=7.36-7.29(\mathrm{~m}, 4 \mathrm{H}, \mathrm{Ar}-\mathrm{H}), 7.28-7.21(\mathrm{~m}, 1 \mathrm{H}, \mathrm{Ar}-H), 5.25-5.31\left(\mathrm{~m}, 1 \mathrm{H}, \mathrm{CH}=\left(\mathrm{CH}_{3}\right)_{2}\right)$, $3.78\left(\mathrm{~s}, 2 \mathrm{H}, \mathrm{PhCH}_{2} \mathrm{~N}\right), 3.23\left(\mathrm{dt},{ }^{3} \mathrm{~J}_{\mathrm{H}, \mathrm{H}}=7.0,1.1 \mathrm{~Hz}, 2 \mathrm{H}, \mathrm{NCH}_{2} \mathrm{CH}=\mathrm{R}\right), 1.73\left(\mathrm{~s}, 3 \mathrm{H}, \mathrm{RCH}=\mathrm{CH}_{3}\left(\mathrm{CH}_{3}\right)\right), 1.62(\mathrm{~s}, 3 \mathrm{H}$, $\left.\mathrm{RCH}=\left(\mathrm{CH}_{3}\right) \mathrm{CH}_{3}\right), 1.45$ (br s, $\left.1 \mathrm{H}, \mathrm{NH}\right) \mathrm{ppm}$.

${ }^{13} \mathrm{C}\left\{{ }^{1} \mathrm{H}\right\}$ NMR $\left(101 \mathrm{MHz}, \mathrm{CDCl}_{3}\right): \delta=140.6,134.6,128.5,128.3,127.0,123.1,53.6,46.8,25.9,18.1 \mathrm{ppm}$.

IR (ATR): $v=3857,3655,3313,3026,2968,2915,2856,2326,2083,1998,1927,1808,1748,1674,1600,1539$, $1492,1447,1373,1304,1188,1091,1027,976,833,733,699 \mathrm{~cm}^{-1}$.

MS (100 eV, Cl): m/z (\%): $176(100)[M+H]^{+}$.

MS (70 eV, EI): m/z (\%): $176(23)[M+H]^{+}, 175$ (17) [M]+, 160 (18), 135 (23), 134 (12), 120 (17), 106 (36), 91 (100) $\left[\mathrm{C}_{7} \mathrm{H}_{7}\right]^{+}, 77(14), 65(14)$.

The NMR data closely match the ones previously reported in the literature. ${ }^{[8]}$ 


\section{$N$-Benzyl-2-bromo-2-methyl-N-(3-methylbut-2-en-1-yl)propanamide (1f)}

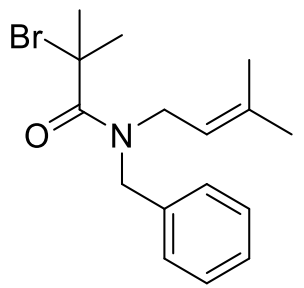

A round bottom flask equipped with a magnetic stirring bar was charged with secondary amine S1c (1.2208 g, $6.96 \mathrm{mmol}, 1.00$ equiv), which was dissolved in $50 \mathrm{~mL}$ distilled $\mathrm{Et}_{2} \mathrm{O}$. The solution was cooled in an ice bath and $\mathrm{NEt}_{3}\left(1.6 \mathrm{~mL}, \rho=0.73 \mathrm{~g} \cdot \mathrm{mL}^{-1}, 11.83 \mathrm{mmol}, 1.70\right.$ equiv) were added. $\alpha$-Bromoisobutyryl bromide $\left(0.9 \mathrm{~mL}, \rho=1.86 \mathrm{~g} \cdot \mathrm{mL}^{-1}, 6.96 \mathrm{mmol}, 1.00\right.$ equiv) was added slowly and a white precipitate formed immediately upon addition. The reaction mixture was allowed to warm up to room temperature and stirred overnight. The next day the reaction was stopped by adding $20 \mathrm{~mL}$ of an aqueous saturated $\mathrm{NH}_{4} \mathrm{Cl}$ solution. The biphasic reaction mixture was stirred vigorously for $15 \mathrm{~min}$ and was then partitioned between $50 \mathrm{~mL}$ of an aqueous saturated $\mathrm{NaHCO}_{3}$ solution and $50 \mathrm{~mL}$ of distilled $\mathrm{Et}_{2} \mathrm{O}$. The phases were separated, and the aqueous phase was extracted three times distilled $\mathrm{Et}_{2} \mathrm{O}(50 \mathrm{~mL})$. The organic phases were combined, dried over $\mathrm{MgSO}_{4}$ and the solvent was removed under reduced pressure. The crude amide was purified by column chromatography $\left(\mathrm{SiO}_{2} / n\right.$ pentane:EtOAc 39:1 $\mathrm{v} / \mathrm{v}$ ) to yield the title compound $\mathbf{1 f}$ as a colorless oil $(1.6207 \mathrm{~g}, 5.00 \mathrm{mmol}, 72 \%)$.

$\mathbf{R}_{\mathbf{f}}=0.56$ ( $n$-pentane:EtOAc 9:1 v/v), UV-active $(254 \mathrm{~nm})$.

${ }^{1} \mathrm{H}$ NMR $\left(600 \mathrm{MHz}\right.$, Toluene- $\left.d_{8}, 95^{\circ} \mathrm{C}\right): \delta=7.15-6.93(\mathrm{~m}, 5 \mathrm{H}, \mathrm{Ar}-\mathrm{H}), 5.12-5.17\left(\mathrm{~m}, 1 \mathrm{H}, \mathrm{RCH}=\left(\mathrm{CH}_{3}\right)_{2}\right), 4.67(\mathrm{~s}, 2 \mathrm{H}$, $\left.\mathrm{PhCH}_{2} \mathrm{~N}\right), 4.11\left(\mathrm{~d}, 3^{3} \mathrm{H}_{\mathrm{H}}=6.5 \mathrm{~Hz}, 2 \mathrm{H}, \mathrm{NCH}_{2} \mathrm{CH}\right), 1.86\left(\mathrm{~s}, 6 \mathrm{H}, 2 \times \mathrm{CH}_{3}\right), 1.55\left(\mathrm{~s}, 3 \mathrm{H}, \mathrm{RCH}=\mathrm{CH}_{3}\left(\mathrm{CH}_{3}\right)\right), 1.32(\mathrm{~s}, 3 \mathrm{H}$, $\left.\mathrm{RCH}=\left(\mathrm{CH}_{3}\right) \mathrm{CH}_{3}\right) \mathrm{ppm}$.

${ }^{13} \mathrm{C}\left\{{ }^{1} \mathrm{H}\right\}$ NMR (151 MHz, Toluene- $\left.d_{8}, 95{ }^{\circ} \mathrm{C}\right): \delta=170.3,138.4,135.9,128.8,128.1,127.5,121.1,58.1,50.9,46.3$, 33.3, 25.6, $17.8 \mathrm{ppm}$.

IR (ATR): $v=3510,3257,2975,2925,2661,2323,2089,1996,1913,1733,1632,1422,1370,1249,1163,1106$, $1030,1001,942,890,841,730 \mathrm{~cm}^{-1}$.

MS (100 eV, Cl): $m / z(\%): 324(20)[M+H]^{+}$.

MS (70 eV, El): m/z (\%): $324(16)[M+H]^{+}, 325(15)[M]^{+}, 244(100), 91(42)\left[\mathrm{C}_{7} \mathrm{H}_{7}\right]^{+}, 69$ (18).

HRMS (ESI): $m / z$ calculated for $\mathrm{C}_{16} \mathrm{H}_{22} \mathrm{BrNO} \mathrm{H}^{+}$: $324.0958[\mathrm{M}+\mathrm{H}]^{+}$; found: 324.0957. 


\section{Mechanochemical synthesis of 2a-f}

\section{General procedure for optimization of reaction conditions}

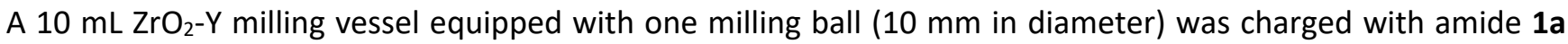
(100.0 mg, $0.34 \mathrm{mmol}$ ), covellite (5-20 mol\%; covellite considered to be pure CuS for calculation). The milling vessel was transferred inside a glove box and ligand I-III 5-20 mol\% was added. The milling vessel was closed, sealed at the seam with parafilm and took out of the glove box. The mechanochemical reaction was conducted for the time indicated in Table 1 at a frequency of $25 \mathrm{~Hz}$. At the end of this time, $1 \mathrm{~mL}$ of $\mathrm{CDCl}_{3}$ was added to the reaction vessel and the crude mixture filtered through a short silica plug directly into a NMR tube. The reported ratio of 2a:1a was calculated based on the integrals of the signals at 2.36-2.48 ppm (2a, $\mathrm{CH})$ and $5.63-5.95 \mathrm{ppm}$ (1a, $\mathrm{RCH}=\mathrm{CH}_{2}$ ).

\section{General procedure for the mechanochemical ATRC of tertiary amides with copper ores}

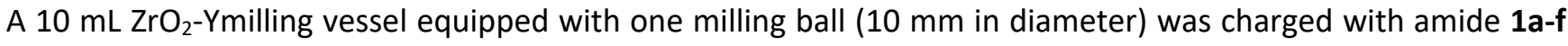
$(0.30 \mathrm{mmol})$ and covellite $(1.4 \mathrm{mg}, 0.015 \mathrm{mmol}, 5 \mathrm{~mol} \%$; covellite considered to be pure CuS for calculation). The jar was transferred inside a glove box and tris[2-(dimethylamino)ethyl]amine (III, $3.5 \mathrm{mg}, 4.1 \mu \mathrm{L}\left(\rho=0.851 \mathrm{~g} \cdot \mathrm{mL}^{-}\right.$ $\left.{ }^{1}\right), 0.015 \mathrm{mmol}, 5 \mathrm{~mol} \%$ ) was added. The vessel was closed, sealed at the seam with parafilm and took out of the glove box. The mechanochemical reaction was conducted for $30 \mathrm{~min}$ at a frequency of $25 \mathrm{~Hz}$. The reaction mixture was transferred in a round bottom flask by adding $\mathrm{CHCl}_{3}(5 \mathrm{~mL})$ to the jar, which was closed and shaken ( 5 times). The products were purified by performing a dry loaded column chromatography.

\section{1-Benzyl-4-(bromomethyl)-3,3-dimethylpyrrolidin-2-one (2a)}

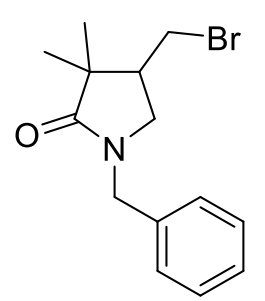

The title compound was synthesized using the general procedure stated above, to yield $2 \mathbf{a}$ after column chromatography $\left(\mathrm{SiO}_{2} / n\right.$-pentane:EtOAc $4: 1 \mathrm{v} / \mathrm{v}$ ) as a colorless oil $(93.5 \mathrm{mg}, 0.32 \mathrm{mmol}$, 94\%).

Upscaling: 1a $297.5 \mathrm{mg}$, Covellite $4.8 \mathrm{mg}$, Me 6 TREN $11.6 \mathrm{mg}(13.6 \mu \mathrm{L})$. Obtained $269.3 \mathrm{mg}$ product after column chromatography ( $n$-pentane:EtOAc 3:1 v/v, $R_{f}=0.11$ ).

Bornite $\left(\mathrm{Cu}_{5} \mathrm{FeS}_{4}\right): 100.4 \mathrm{mg} 1 \mathrm{a}, 1.7 \mathrm{mg}$ Bornite, $4.6 \mu \mathrm{L} \mathrm{Me} 6$ TREN, $97.0 \mathrm{mg}$ product after column chromatography (n-pentane:EtOAc 3:1 v/v, $R_{f}=0.11$ ).

$\mathbf{R}_{\mathbf{f}}=0.11$ ( $n$-Pentane:EtOAc 3:1 v/v), slightly UV-active, stains with $\mathrm{KMnO}_{4}$.

${ }^{1} \mathrm{H}$ NMR (600 MHz, $\left.\mathrm{CDCl}_{3}\right): \delta=7.33(\mathrm{~m}, 2 \mathrm{H}, \mathrm{Ar}-\mathrm{H}), 7.29(\mathrm{~m}, 1 \mathrm{H}, \mathrm{Ar}-\mathrm{H}), 7.21(\mathrm{~m}, 2 \mathrm{H}, \mathrm{Ar}-\mathrm{H}), 4.53\left(\mathrm{~d},{ }^{3} \mathrm{~J}_{\mathrm{H}, \mathrm{H}}=14.6 \mathrm{~Hz}\right.$, $\left.1 \mathrm{H}, \mathrm{PhCH} \mathrm{A}_{\mathrm{B}} \mathrm{N}\right), 4.38\left(\mathrm{~d},{ }^{3} \mathrm{~J}_{\mathrm{H}, \mathrm{H}}=14.6 \mathrm{~Hz}, 1 \mathrm{H}, \mathrm{PhCH}_{\mathrm{A}} H_{\mathrm{B}}\right), 3.49\left(\mathrm{dd},{ }^{3} \mathrm{~J}_{\mathrm{H}, \mathrm{H}}=10.1,4.8 \mathrm{~Hz}, 1 \mathrm{H}, \mathrm{CH}_{\mathrm{A}} \mathrm{H}_{\mathrm{B}} \mathrm{Br}\right), 3.38\left(\mathrm{dd},{ }^{3} \mathrm{~J}_{\mathrm{H}, \mathrm{H}}=\right.$ 10.1, 7.6 Hz, $1 \mathrm{H}, \mathrm{CH}_{\mathrm{A}} \mathrm{H}_{\mathrm{B}} \mathrm{Br}$ ), $3.25\left(\mathrm{t},{ }^{3} \mathrm{~J}_{\mathrm{H}, \mathrm{H}}=10.4 \mathrm{~Hz}, 1 \mathrm{H}, \mathrm{NCH}_{\mathrm{A}} \mathrm{H}_{\mathrm{B}}\right.$ ), $2.90\left(\mathrm{dd},{ }^{3} \mathrm{~J}_{\mathrm{H}, \mathrm{H}}=10.1,8.6 \mathrm{~Hz}, 1 \mathrm{H}, \mathrm{NCH}_{\mathrm{A}} \mathrm{H}_{\mathrm{B}}\right.$ ), 2.43 (dddd, $\left.{ }^{3} J_{\mathrm{H}, \mathrm{H}}=10.8,8.6,7.6,4.8 \mathrm{~Hz}, 1 \mathrm{H}, \mathrm{CH}\right), 1.26\left(\mathrm{~s}, 3 \mathrm{H}, \mathrm{CH}_{3}\right), 1.01\left(\mathrm{~s}, 3 \mathrm{H}, \mathrm{CH}_{3}\right) \mathrm{ppm}$.

${ }^{13} \mathrm{C}\left\{{ }^{1} \mathrm{H}\right\}$ NMR $\left(151 \mathrm{MHz}, \mathrm{CDCl}_{3}\right): \delta=178.6,136.5,128.9,128.2,127.8,49.0,46.8,46.2,44.2,31.5,24.4,18.5 \mathrm{ppm}$.

IR (ATR): $v=3474,3029,2965,2927,2868,2325,2082,1894,1685,1491,1434,1360,1321,1269,1165,1079$, $1035,998,947,809,748,700,673 \mathrm{~cm}^{-1}$.

MS (100 eV, Cl): $m / z(\%): 296(27)[M+H]^{+}$. 
MS (70 eV, El): m/z (\%): $296(50)[M+H]^{+}, 295[M]^{+}(46), 216(9), 202(10), 92(20), 91(100)\left[C_{7} \mathrm{H}_{7}\right]^{+}, 65(20), 55$ (11).

The NMR data closely match the ones previously reported in the literature. ${ }^{[5]}$

\section{4-(Bromomethyl)-1,3,3-trimethylpyrrolidin-2-one (2b)}<smiles>CN1CC(CBr)C(C)(C)C1=O</smiles>

The title compound was synthesized using the general procedure stated above. $\mathbf{1 b}(102.3 \mathrm{mg}$, $0.46 \mathrm{mmol}$ ), covellite $(2.2 \mathrm{mg}, 0.02 \mathrm{mmol}, 5 \mathrm{~mol} \%)$ and ligand III (= Me 6 TREN, $5.3 \mathrm{mg}, 6.2 \mu \mathrm{L}(\rho$ $\left.\left.=0.851 \mathrm{~g} \cdot \mathrm{mL}^{-1}\right), 0.02 \mathrm{mmol}, 5 \mathrm{~mol} \%\right)$ were used, to yield $\mathbf{2 b}$ after column chromatography $\left(\mathrm{SiO}_{2} / \mathrm{n}\right.$-pentane:EtOAc $\left.1: 1 \mathrm{v} / \mathrm{v}\right)$ as a colorless oil $(80.7 \mathrm{mg}, 0.36 \mathrm{mmol}, 79 \%)$.

$\mathbf{R}_{\mathbf{f}}=0.40$ ( $n$-pentane:EtOAc $1: 1 \mathrm{v} / \mathrm{v}$ ), not UV-active, stains with $\mathrm{KMnO}_{4}$ after heating.

${ }^{1} \mathrm{H}$ NMR $\left(600 \mathrm{MHz}, \mathrm{CDCl}_{3}\right): \delta=3.43-3.53\left(\mathrm{~m}, 2 \mathrm{H}, \mathrm{BrCH}_{\mathrm{A}} \mathrm{H}_{\mathrm{B}} \mathrm{CH}+\mathrm{CHCH}_{\mathrm{A}} \mathrm{H}_{\mathrm{B}} \mathrm{N}\right), 3.30\left(\mathrm{dd},{ }^{3} \mathrm{~J}_{\mathrm{H}, \mathrm{H}}=11.0,11.0 \mathrm{~Hz}, 1 \mathrm{H}\right.$ $\mathrm{CHCH}_{\mathrm{A}} \mathrm{H}_{\mathrm{B}} \mathrm{N}$ ), $3.05\left(\mathrm{dd},{ }^{3} \mathrm{H}_{\mathrm{H}, \mathrm{H}}=9.7,8.4 \mathrm{~Hz}, 1 \mathrm{H}, \mathrm{BrCH}_{\mathrm{A}} \mathrm{H}_{\mathrm{B}} \mathrm{CH}\right), 2.84\left(\mathrm{~s}, 3 \mathrm{H}, \mathrm{NCH}\right.$ ), 2.40-2.49 (m, $\left.1 \mathrm{H}, \mathrm{BrCH}_{2} \mathrm{RCHCH}_{2}\right)$, $1.19\left(\mathrm{~s}, 3 \mathrm{H}, \mathrm{CH}_{3}(\mathrm{~A})\right), 0.97\left(\mathrm{~s}, 3 \mathrm{H}, \mathrm{CH}_{3}(\mathrm{~B})\right) \mathrm{ppm}$.

${ }^{13} \mathrm{C}\left\{{ }^{1} \mathrm{H}\right\}$ NMR (151 MHz, $\left.\mathrm{CDCl}_{3}\right): \delta=178.6,51.8,46.2,44.0,31.7,29.9,24.5,18.5 \mathrm{ppm}$.

IR (ATR): $v=3482,2964,2928,2870,2161,162,1496,1438,1401,1363,1274,1174,1083,1025,971,731,673$ $\mathrm{cm}^{-1}$.

MS (70 eV, El): $m / z(\%): 223(11)[M+H]^{+}, 222(100)[M]^{+}, 221(23)[M+H]^{+}, 220(95)[M]^{+}, 219(14), 140(64), 126$ (19), 83 (14), 69 (24), 55 (22).

HRMS: calculated for $\mathrm{C}_{8} \mathrm{H}_{14} \mathrm{BrNONa}[\mathrm{M}+\mathrm{Na}]^{+}:$242.0157; found: 242.0151 .

\section{4-(Bromomethyl)-3,3-dimethyl-1-tosylpyrrolidin-2-one (2c)}<smiles>Cc1ccc(S(=O)(=O)N2CC(CBr)C(C)(C)C2=O)cc1</smiles>

The title compound was synthesized using the general procedure stated above to yield $\mathbf{2 c}$ after column chromatography $\left(\mathrm{SiO}_{2} / n\right.$-pentane:EtOAc 3:1 $\mathrm{v} / \mathrm{v}$ ) as a white solid (20.0 mg, 0.05 $\mathrm{mmol}, 18 \%$; for an extended milling time of $90 \mathrm{~min}: 32.4 \mathrm{mg}, 0.09 \mathrm{mmol}, 30 \%)$.

$\mathbf{R}_{\mathbf{f}}=0.20$ ( $n$-pentane:EtOAc 3:1 v/v), UV-active.

m.p.: $127.4-128.1^{\circ} \mathrm{C}$.

${ }^{1} \mathrm{H}$ NMR (600 MHz, $\left.\mathrm{CDCl}_{3}\right): \delta=7.80-7.85(\mathrm{~m}, 2 \mathrm{H}, \mathrm{Ar}-\mathrm{H}), 7.30-7.35(\mathrm{~m}, 2 \mathrm{H}, \mathrm{Ar}-\mathrm{H}), 4.14\left(\mathrm{dd},{ }^{3} \mathrm{~J}_{\mathrm{H}, \mathrm{H}}=10.1,7.5 \mathrm{~Hz}\right.$, $\left.1 \mathrm{H}, \mathrm{BrCH}_{\mathrm{A}} \mathrm{H}_{\mathrm{B}} \mathrm{CH}\right), 3.40-3.50\left(\mathrm{~m}, 2 \mathrm{H}, \mathrm{BrCH}_{\mathrm{A}} \mathrm{H}_{\mathrm{B}} \mathrm{CH}+\mathrm{CHCH}_{\mathrm{A}} \mathrm{H}_{\mathrm{B}} \mathrm{N}\right), 3.24\left(\mathrm{dd},{ }^{3} J_{\mathrm{H}, \mathrm{H}}=11.0,11.0 \mathrm{~Hz}, 1 \mathrm{H}, \mathrm{CHCH}_{\mathrm{A}} H_{\mathrm{B}} \mathrm{N}\right), 2.41-$ $2.48\left(\mathrm{~m}, 4 \mathrm{H}, \mathrm{BrCH}_{2} \mathrm{RCHCH}_{2}+\mathrm{CH}_{3}(\mathrm{~A})\right), 1.18\left(\mathrm{~s}, 3 \mathrm{H}, \mathrm{Ar}-\mathrm{CH}_{3}\right), 0.89\left(\mathrm{~s}, 3 \mathrm{H}, \mathrm{CH}_{3}(\mathrm{~B})\right) \mathrm{ppm}$.

${ }^{13} \mathrm{C}\left\{{ }^{1} \mathrm{H}\right\}$ NMR (151 MHz, $\left.\mathrm{CDCl}_{3}\right): \delta=177.0,145.5,135.0,129.9,128.1,48.9,45.5,45.2,29.9,23.6,21.8,18.0 \mathrm{ppm}$.

IR (ATR): $v=3286,2972,2922,2854,2162,1724,1597,1455,1352,1237,1163,1115,939,881,811,749,659$ $\mathrm{cm}^{-1}$. 
MS (EI, 70 eV): m/z (\%): $362(31)[M+H]^{+}, 360(35)[M+H]^{+}, 297$ (78), 295 (100), 92 (22), 91 (61), 69 (37), 65 (28), $56(25)$.

HRMS: calculated for $\mathrm{C}_{14} \mathrm{H}_{18} \mathrm{BrNO}_{3} \mathrm{~S}+\mathrm{Na}^{+}:[\mathrm{M}+\mathrm{Na}]^{+}: 382.0091$; found: 382.0083 .

\section{1-Benzyl-4-(bromomethyl)-3,3,4-trimethylpyrrolidin-2-one (2d)}<smiles>CC1(C)CN(Cc2ccccc2)C(=O)C1(C)CBr</smiles>

The title compound was synthesized using the general procedure stated above. 1d $(93.1 \mathrm{mg}$, $0.30 \mathrm{mmol}$ ), covellite (1.4 mg, $0.015 \mathrm{mmol}, 5 \mathrm{~mol} \%$ ) and ligand III (= Me 6 TREN, $3.5 \mathrm{mg}, 4.1 \mu \mathrm{l}$ $\left.\left(\rho=0.851 \mathrm{~g} \cdot \mathrm{mL}^{-1}\right), 0.015 \mathrm{mmol}, 5 \mathrm{~mol} \%\right)$ were used, to yield $\mathbf{2} \mathbf{d}$ after column chromatography $\left(\mathrm{SiO}_{2} / \mathrm{n}\right.$-pentane:EtOAc 4:1 $\rightarrow 1: 1 \mathrm{v} / \mathrm{v}$ ) as a transparent oil $(83.7 \mathrm{mg}, 0.27 \mathrm{mmol}, 90 \%)$.

$\mathbf{R}_{\mathbf{f}}=0.48$ ( $n$-pentane:EtOAc 1:1 $\left.\mathrm{v} / \mathrm{v}\right)$, UV-active $(254 \mathrm{~nm})$, stains with $\mathrm{I}_{2}$.

${ }^{1} \mathrm{H}$ NMR (600 MHz, $\left.\mathrm{CDCl}_{3}\right): \delta=7.33(\mathrm{~m}, 2 \mathrm{H}, \mathrm{Ar}-\mathrm{H}), 7.28(\mathrm{~m}, 1 \mathrm{H}, \mathrm{Ar}-\mathrm{H}), 7.22(\mathrm{~m}, 2 \mathrm{H}, \mathrm{Ar}-\mathrm{H}), 4.32-4.50(\mathrm{~m}, 2 \mathrm{H}$, $\mathrm{PhCH}_{2} \mathrm{~N}$ ), $3.42\left(\mathrm{~d},{ }^{3} \mathrm{~J}_{\mathrm{H}, \mathrm{H}}=10.2 \mathrm{~Hz}, 1 \mathrm{H}, \mathrm{CH}_{\mathrm{A}} \mathrm{H}_{\mathrm{B}} \mathrm{Br}\right), 3.34\left(\mathrm{~d},{ }^{3} \mathrm{~J}_{\mathrm{H}, \mathrm{H}}=10.2 \mathrm{~Hz}, 1 \mathrm{H}, \mathrm{CH}_{\mathrm{A}} \mathrm{H}_{\mathrm{B}} \mathrm{Br}\right), 3.19\left(\mathrm{~d},{ }^{3} J_{\mathrm{H}, \mathrm{H}}=10.2 \mathrm{~Hz}, 1 \mathrm{H}\right.$, $\left.\mathrm{NH}_{\mathrm{A}} \mathrm{H}_{\mathrm{B}}\right), 2.84\left(\mathrm{~d}, 3_{\mathrm{H}, \mathrm{H}}=10.2 \mathrm{~Hz}, 1 \mathrm{H}, \mathrm{NH}_{\mathrm{A}} H_{\mathrm{B}}\right), 1.13\left(\mathrm{~s}, 3 \mathrm{H},(\mathrm{C}=\mathrm{O}) \mathrm{C}\left(\mathrm{CH}_{3}\right) \mathrm{CH}_{3}\right), 1.10\left(\mathrm{~s}, 3 \mathrm{H}, \mathrm{CH}_{3}\right), 1.07(\mathrm{~s}, 3 \mathrm{H}$, $\left.(\mathrm{C}=\mathrm{O}) \mathrm{CCH}_{3}\left(\mathrm{CH}_{3}\right)\right) \mathrm{ppm}$.

${ }^{13} \mathrm{C}\left\{{ }^{1} \mathrm{H}\right\}$ NMR (151 MHz, $\left.\mathrm{CDCl}_{3}\right): \delta=178.4,136.5,128.9,128.3,127.8,54.4,47.2,46.8,43.0,40.5,20.3,20.0,19.4$ ppm.

IR (ATR): $v=3870,3479,3030,2972,2928,2871,2662,2327,2085,1989,1908,1805,1686,1492,1432,1376$, $1310,1263,1165,1110,1079,1028,949,853,814,748,700,668 \mathrm{~cm}^{-1}$.

MS (100 eV, Cl): m/z (\%): $310(95)[M+H]^{+}$.

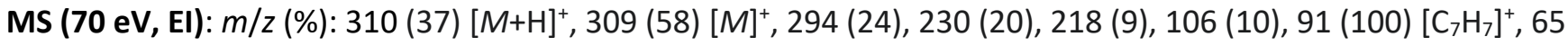
(15), 55 (15).

HRMS (ESI): $m / z$ calculated for $\mathrm{C}_{15} \mathrm{H}_{20} \mathrm{BrNO}+\mathrm{Na}^{+}: 332.0621[\mathrm{M}+\mathrm{Na}]^{+}$; found: 332.0619 .

\section{(E)-1-Benzyl-4-(3-bromobut-1-en-1-yl)-3,3-dimethylpyrrolidin-2-one (2e)}

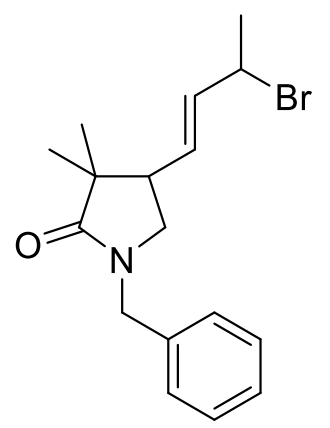

The title compound was synthesized using the general procedure stated above. 1e (101.0 $\mathrm{mg}, 0.30 \mathrm{mmol}$ ), covellite (1.4 mg, $0.02 \mathrm{mmol}, 5 \mathrm{~mol} \%$ ) and ligand III (= Me 6 TREN, $3.5 \mathrm{mg}$, $\left.4.1 \mu \mathrm{L}\left(\rho=0.851 \mathrm{~g} \cdot \mathrm{mL}^{-1}\right), 0.02 \mathrm{mmol}, 5 \mathrm{~mol} \%\right)$ were used, to yield $2 \mathrm{e}$ after column chromatography $\left(\mathrm{SiO}_{2} / n\right.$-pentane:EtOAc 3:1 $\left.\mathrm{v} / \mathrm{v}\right)$ as a transparent oil mixture of two diasteromers in 1:1 d.r. (12.3 $\mathrm{mg}, 0.04 \mathrm{mmol}, 12 \%)$.

After 90 min of milling: $28.9 \mathrm{mg}, 0.09 \mathrm{mmol}, 27 \%$.

${ }^{1} \mathrm{H}$ NMR $\left(600 \mathrm{MHz}, \mathrm{CDCl}_{3}\right): \delta=7.30-7.35(\mathrm{~m}, 2 \mathrm{H}, \mathrm{Ar}-H), 7.30-7.35(\mathrm{~m}, 2 \mathrm{H}, \mathrm{Ar}-\mathrm{H}), 7.26-$ $7.30(\mathrm{~m}, 1 \mathrm{H}, \mathrm{Ar}-\mathrm{H}), 7.26-7.30(\mathrm{~m}, 1 \mathrm{H}, \mathrm{Ar}-H), 7.19-7.23(\mathrm{~m}, 2 \mathrm{H}, \mathrm{Ar}-\mathrm{H}), 7.19-7.23(\mathrm{~m}, 2 \mathrm{H}, \mathrm{Ar}-H), 5.75-5.81(\mathrm{~m}$, $1 \mathrm{H}, \mathrm{BrCHCH}=\mathrm{CHR}), 5.75-5.81(\mathrm{~m}, 1 \mathrm{H}, \mathrm{BrCHCH}=\mathrm{CHR}), 5.52-5.60(\mathrm{~m}, 1 \mathrm{H}, \mathrm{BrCHCH}=\mathrm{CHR}), 5.52-5.60(\mathrm{~m}, 1 \mathrm{H}$, $\mathrm{BrCHCH}=\mathrm{CHR}), 4.61-4.69(\mathrm{~m}, 1 \mathrm{H}, \mathrm{BrCH}), 4.61-4.69(\mathrm{~m}, 1 \mathrm{H}, \mathrm{BrCH}), 4.51\left(\mathrm{~d},{ }^{2} \mathrm{~J}_{\mathrm{H}, \mathrm{H}}=14.8 \mathrm{~Hz}, 1 \mathrm{H}, \mathrm{NCH}_{\mathrm{A}} \mathrm{H}_{\mathrm{B}} \mathrm{Ph}\right), 4.51(\mathrm{~d}$, 
$\left.{ }^{2} J_{\mathrm{H}, \mathrm{H}}=14.8 \mathrm{~Hz}, 1 \mathrm{H}, \mathrm{NCH}_{\mathrm{A}} \mathrm{H}_{\mathrm{B}} \mathrm{Ph}\right), 4.40\left(\mathrm{~d},{ }^{2} J_{\mathrm{H}, \mathrm{H}}=14.8 \mathrm{~Hz}, 1 \mathrm{H}, \mathrm{NCH}_{\mathrm{A}} H_{\mathrm{B}} \mathrm{Ph}\right), 4.40\left(\mathrm{~d},{ }^{2} J_{\mathrm{H}, \mathrm{H}}=14.8 \mathrm{~Hz}, 1 \mathrm{H}, \mathrm{NCH}_{\mathrm{A}} H_{\mathrm{B}} \mathrm{Ph}\right)$, 3.16-3.23 (m, 1H, $\left.\mathrm{CHCH}_{\mathrm{A}} \mathrm{H}_{\mathrm{B}} \mathrm{N}\right)$, 3.16-3.23 (m, 1H, $\left.\mathrm{CHCH}_{\mathrm{A}} \mathrm{H}_{\mathrm{B}} \mathrm{N}\right), 2.94-3.01\left(\mathrm{~m}, 1 \mathrm{H}, \mathrm{CHCH}_{\mathrm{A}} \mathrm{H}_{\mathrm{B}} \mathrm{N}\right), 2.94-3.01(\mathrm{~m}, 1 \mathrm{H}$, $\left.\mathrm{CHCH}_{\mathrm{A}} \mathrm{H}_{\mathrm{B}} \mathrm{N}\right), 2.53-2.60\left(\mathrm{~m}, 1 \mathrm{H}, \mathrm{BrCH}_{2} \mathrm{RCHCH}_{2}\right), 2.53-2.60\left(\mathrm{~m}, 1 \mathrm{H}, \mathrm{BrCH}_{2} \mathrm{RCHCH}_{2}\right), 1.75\left(\mathrm{~d}, 3_{\mathrm{H}, \mathrm{H}}=6.8 \mathrm{~Hz}, 3 \mathrm{H}\right.$, $\left.\mathrm{BrCHCH}_{3}\right), 1.74\left(\mathrm{~d},{ }^{3} \mathrm{JH}_{\mathrm{H}} \mathrm{H}=6.8 \mathrm{~Hz}, 3 \mathrm{H}, \mathrm{BrCHCH}_{3}\right), 1.18\left(\mathrm{~s}, 3 \mathrm{H}, \mathrm{CH}_{3}(\mathrm{~A})\right), 1.19\left(\mathrm{~s}, 3 \mathrm{H}, \mathrm{CH}_{3}(\mathrm{~A})\right), 0.96\left(\mathrm{~s}, 3 \mathrm{H}, \mathrm{CH}_{3}(\mathrm{~B})\right), 0.95$ (s, $\left.3 \mathrm{H}, \mathrm{CH}_{3}(\mathrm{~B})\right)$ ppm;

${ }^{13} \mathrm{C}\left\{{ }^{1} \mathrm{H}\right\}$ NMR (151 MHz, $\left.\mathrm{CDCl}_{3}\right): \delta=179.0,178.9,136.6,136.6,136.5,136.4,128.9,128.2,128.0,127.9,127.8$, $127.8,48.7,48.5,48.1,48.0,46.9,46.8,46.7,44.5,44.4,26.2,26.0,23.6,23.6,19.3,19.2$ ppm.

The configuration of the double bond was determined after 1D Selective Gradient $\mathrm{H}, \mathrm{H}-\mathrm{COSY}$ analysis on the multiplet at 5.75-5.81 ppm: ${ }^{3} J_{\mathrm{H}, \mathrm{H}}=16.4 \mathrm{~Hz}$, which indicated an E-configuration.

IR (ATR): $v=3029,2964,2924,2866,2327,2099,1685,1491,1431,1361,1266,1170,1003,969,750$, $700 \mathrm{~cm}^{-1}$.

MS (EI, $70 \mathrm{eV}): m / z(\%)=338(15)[M+H]^{+}, 337(38)[M]^{+}, 336(19)[M+H]^{+}, 335(51)[M]^{+}, 256(68), 202(46), 123$ (29), 91 (100), $81(24)$.

MS (100 eV, Cl): m/z (\%): $338(56)[M+H]^{+}, 336(59)[M+H]^{+}, 257(20), 256(100)$.

HRMS: calculated for $\mathrm{C}_{18} \mathrm{H}_{23} \mathrm{BrNO}[\mathrm{M}+\mathrm{H}]^{+}$: 336.0964; found: 336.0958 .

1-Benzyl-3,3-dimethyl-4-(prop-1-en-2-yl)pyrrolidin-2-one ylidene)pyrrolidin-2-one (2f') (2f) and 1-benzyl-3,3-dimethyl-4-(propan-2-<smiles>C=C(C)C1CN(Cc2ccccc2)C(=O)C1(C)C</smiles>

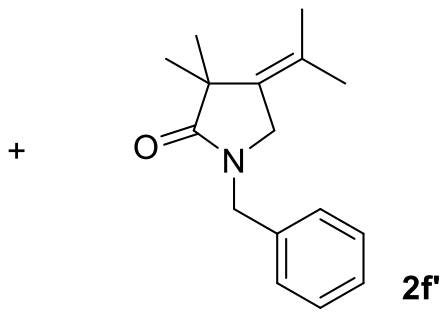

The title isomeric mixture was synthesized using the general procedure described above. 1 f $(97.3 \mathrm{mg}, 0.30$ $\mathrm{mmol}$ ), covellite (1.4 mg, $0.015 \mathrm{mmol}, 5 \mathrm{~mol} \%)$ and ligand III (= Me 6 TREN, $3.5 \mathrm{mg}, 4.1 \mu \mathrm{l}\left(\rho=0.851 \mathrm{~g} \cdot \mathrm{mL}^{-1}\right), 0.015$ mmol, 5 mol\%) were used, to yield a mixture of isomers $\mathbf{2} \mathbf{f}$ and $\mathbf{2} \mathbf{f}^{\prime}(61: 39)$ after column chromatography $\left(\mathrm{SiO}_{2} / \mathbf{n}\right.$ pentane:EtOAc 4:1 v/v) as a transparent oil $(43.5 \mathrm{mg}, 0.18 \mathrm{mmol}, 59 \%)$. For a milling time of $90 \mathrm{~min}(71.6 \mathrm{mg}$, $0.29 \mathrm{mmol}, 98 \%$, 2f:2f' 46:54).

The expected bromine derivative was not obtained as it underwent elimination to yield the olefins $\mathbf{2 f}$ and $\mathbf{2} \mathbf{f}^{\prime}$. $\mathbf{R}_{\mathbf{f}}=0.46-0.58(n-$ pentane:EtOAc $1: 1 \mathrm{v} / \mathrm{v})$, stains with $\mathrm{KMnO}_{4}$. 
${ }^{1} \mathbf{H}$ NMR (600 MHz, CDCl $): \delta(\mathbf{2 f})=7.35(\mathrm{~m}, 2 \mathrm{H}, \mathrm{Ar}-H), 7.30(\mathrm{~m}, 1 \mathrm{H}, \mathrm{Ar}-\mathrm{H}), 7.25(\mathrm{~m}, 2 \mathrm{H}, \mathrm{Ar}-\mathrm{H}), 4.90(\mathrm{~m}, 1 \mathrm{H}$, $\left.\mathrm{R}=\mathrm{CH}_{\mathrm{A}} \mathrm{H}_{\mathrm{B}}\right), 4.70\left(\mathrm{~m}, 1 \mathrm{H}, \mathrm{R}=\mathrm{CH}_{\mathrm{A}} H_{\mathrm{B}}\right), 4.50\left(\mathrm{~m}, 2 \mathrm{H}, \mathrm{PhCH}_{2} \mathrm{~N}\right), 3.19\left(\mathrm{~m}, 2 \mathrm{H}, \mathrm{NCH}_{2} \mathrm{CHR}_{2}\right), 2.61\left(\mathrm{t},{ }^{3} J_{\mathrm{H}, \mathrm{H}}=\mathrm{Hz}, 1 \mathrm{H}, \mathrm{CH}\right), 1.73$ $\left(\mathrm{s}, 3 \mathrm{H}, \mathrm{H}_{2} \mathrm{C}=\mathrm{CRCH}_{3}\right), 1.31\left(\mathrm{~s}, 3 \mathrm{H},(\mathrm{C}=\mathrm{O}) \mathrm{C}\left(\mathrm{CH}_{3}\right) \mathrm{CH}_{3}\right), 0.98\left(\mathrm{~s}, 3 \mathrm{H},(\mathrm{C}=\mathrm{O}) \mathrm{CCH}_{3}\left(\mathrm{CH}_{3}\right)\right) \mathrm{ppm} ; \delta(\mathbf{2 f})=7.35(\mathrm{~m}, 2 \mathrm{H}, \mathrm{Ar}-\mathrm{H})$, $7.30(\mathrm{~m}, 1 \mathrm{H}, \mathrm{Ar}-\mathrm{H}), 7.25(\mathrm{~m}, 2 \mathrm{H}, \mathrm{Ar}-\mathrm{H}), 4.54\left(\mathrm{~s}, 2 \mathrm{H}, \mathrm{PhCH}_{2} \mathrm{~N}\right), 3.75\left(\mathrm{~s}, 2 \mathrm{H}, \mathrm{NCH}_{2} \mathrm{R}\right), 1.80\left(\mathrm{~s}, 3 \mathrm{H}, \mathrm{R}=\left(\mathrm{CH}_{3}\right) \mathrm{CH}_{3}\right), 1.53$ $\left(\mathrm{s}, 3 \mathrm{H}, \mathrm{R}=\mathrm{CH}_{3}\left(\mathrm{CH}_{3}\right)\right), 1.40\left(\mathrm{~s}, 6 \mathrm{H},(\mathrm{C}=\mathrm{O}) \mathrm{C}\left(\mathrm{CH}_{3}\right)_{2}\right) \mathrm{ppm}$.

${ }^{13} \mathrm{C}\left\{{ }^{1} \mathrm{H}\right\}$ NMR (151 MHz, $\left.\mathrm{CDCl}_{3}\right): \delta(\mathbf{2 f})=179.0,142.4,136.7,128.8,128.3,127.7,113.2,50.7,46.9,46.8,43.8$, 25.4, 23.1, 19.2 ppm; $\delta\left(\mathbf{2 f}^{\prime}\right)=179.6,136.6,130.5,128.8,128.1,127.6,126.1,49.4,46.4,44.2,24.4,21.4,20.2$ ppm.

IR (ATR): $v=3866,3372,2966,2925,2661,2328,2095,1996,1910,1685,1491,1437,1363,1264,1157,1079$, $1029,896,815,745,701 \mathrm{~cm}^{-1}$.

MS (100 eV, Cl): $m / z(\%): 244(100)[M+H]^{+}$.

MS (70 eV, El): m/z (\%): $244(50)[M+H]^{+}, 243(96)[M]^{+}, 228(36), 152(17), 91(100)\left[C_{7} \mathrm{H}_{7}\right]^{+}, 65(20), 55$ (13).

\section{Considerations on the mechanism for the formation of $2 e$}

It is assumed that the stability of intermediate $\mathbf{1 1 e}$ reduced the rate in the formation of product $\mathbf{2 e}$, thus lowering its yield after the same reaction time compared to other substrates used.

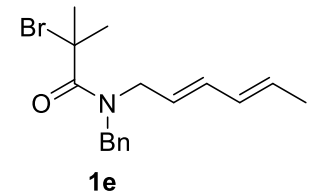

$1 e$
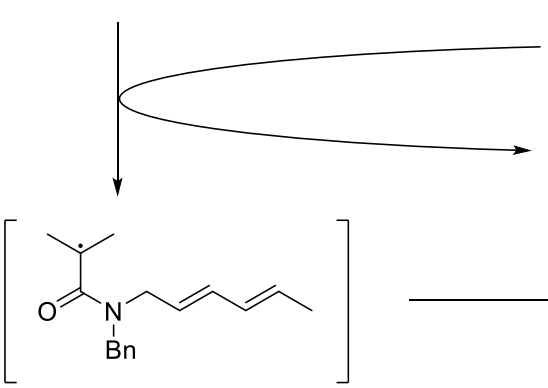

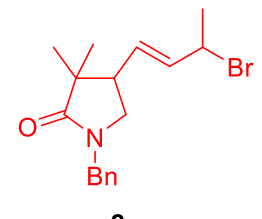

$2 e$

$\mathrm{Cu}^{\prime}(\mathrm{L})$
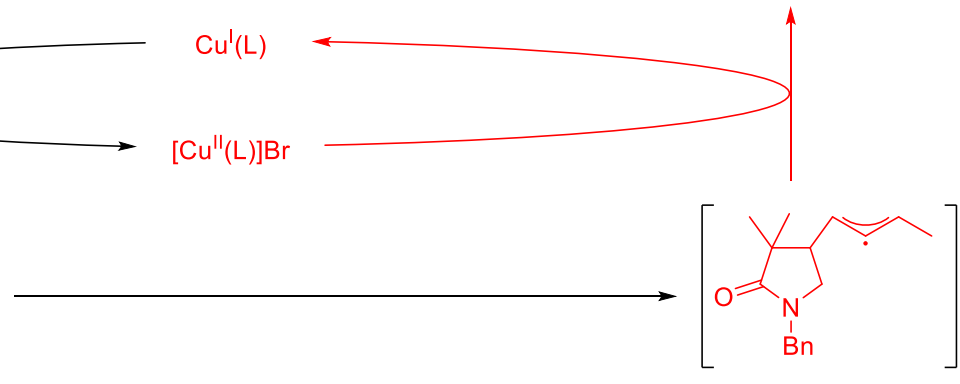

I1e

Scheme S1 - Proposed reaction mechanism for the formation of $\mathbf{2 e .}$ 


\section{Synthesis of substrates $3 e$ and $3 f$}

\section{6-Phenylnaphthalen-2-ol (3e)}

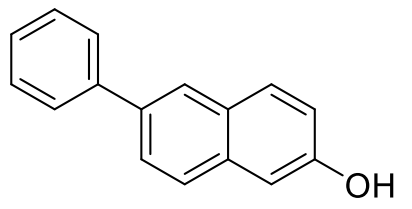

A round bottom Schlenk flask equipped with a magnetic stirring bar was flushed with argon and charged with $22 \mathrm{~mL}$ of toluene and $23 \mathrm{~mL}$ of an aqueous $2 \% \mathrm{Na}_{2} \mathrm{CO}_{3}$ solution. To this mixture, 6-bromo-2-naphthol (1000.0 mg, $4.48 \mathrm{mmol}, 1.00$ equiv),

phenylboronic acid (546.6 mg, $4.48 \mathrm{mmol}, 1.00$ equiv) and $\left[\mathrm{Pd}\left(\mathrm{PPh}_{3}\right)_{4}\right](517.7 \mathrm{mg}$, $0.448 \mathrm{mmol}, 0.10$ equiv) were added under argon flow and the mixture stirred at $80^{\circ} \mathrm{C}$ for $22 \mathrm{~h}$ in an oil bath. At the end of this time, $15 \mathrm{~mL}$ of water were added, the crude mixture was vacuum filtrated and extracted three times with DCM $(20 \mathrm{~mL})$. The combined organic phases were washed once with $10 \mathrm{~mL}$ of an aqueous saturated $\mathrm{NaCl}$ solution, dried over $\mathrm{MgSO}_{4}$ and the solvent removed under reduced pressure. The 6-phenylnaphthalen-2ol product (3e) was obtained as a yellow solid $(423.7 \mathrm{mg}, 1.93 \mathrm{mmol}, 43 \%)$ after column chromatography $\left(\mathrm{SiO}_{2} / n\right.$ pentane:EtOAc 4:1 v/v).

$\mathbf{R}_{\mathbf{f}}=0.60$ ( $n$-pentane:EtOAc 2:1 v/v), UV-active.

m.p.: $174.1-175.6^{\circ} \mathrm{C}$.

${ }^{1} \mathrm{H}$ NMR (400 MHz, DMSO-d $\left.\boldsymbol{d}_{6}\right): \delta=9.98-9.63(\mathrm{br} \mathrm{s}, 1 \mathrm{H}, \mathrm{Ar}-\mathrm{OH}), 8.00-8.12(\mathrm{~m}, 1 \mathrm{H}, \mathrm{Ar}-H), 7.86-7.82(\mathrm{~m}, 1 \mathrm{H}, \mathrm{Ar}-$ $H)$, 7.79-7.74 (m, 3H, Ar-H), 7.74-7.70 (m, 1H, Ar-H), 7.51-7.45 (m, 1H, Ar-H), 7.38-7.33 (m, 2H, Ar-H), 7.16$7.13(\mathrm{~m}, 1 \mathrm{H}, \mathrm{Ar}-H), 7.12-7.08(\mathrm{~m}, 1 \mathrm{H}, \mathrm{Ar}-H)$.

${ }^{13} \mathrm{C}\left\{{ }^{1} \mathrm{H}\right\}$ NMR (101 MHz, DMSO-d $\left.\boldsymbol{d}_{6}\right): \delta=155.6,140.3,134.3,133.9,129.8,128.9,128.0,127.0,126.7,126.6,125.2$, 125.1, 119.1, $108.4 \mathrm{ppm}$.

IR (ATR): $v=3327,3056,3030,2922,2853,2696,2321,2109,1897,1814,1772,1630,1601,1491,1451,1354$, $1273,1227,1192,1150,960,861,807,755,696,667 \mathrm{~cm}^{-1}$.

MS (El, 70 eV): m/z (\%): $221(17)[M+H]^{+}, 220(100)[M]^{+}, 191(20), 189(22), 165$ (16).

The NMR data closely match the ones previously reported in the literature. ${ }^{[9]}$

\section{[1,2'-Binaphthalen]-6'-ol (3f)}

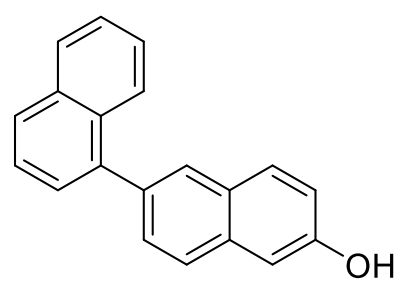

A round bottom Schlenk flask equipped with a magnetic stirring bar was flushed with argon and charged with 6-bromo-2-naphthol (500.0 mg, $2.24 \mathrm{mmol}, 1.00$ equiv), $\left[\mathrm{Pd}\left(\mathrm{PPh}_{3}\right)_{4}\right]\left(207.1 \mathrm{mg}, 0.179 \mathrm{mmol}, 0.08\right.$ equiv), $\mathrm{Na}_{2} \mathrm{CO}_{3}(1.0 \mathrm{~g}, 9.86 \mathrm{mmol}, 4.40$ equiv), $7 \mathrm{~mL}$ of $\mathrm{H}_{2} \mathrm{O}$ and $7 \mathrm{~mL}$ of toluene. To this mixture, a solution of 1naphthylboronic acid (500.5 mg, $2.91 \mathrm{mmol}, 1.30$ equiv) in $9 \mathrm{~mL}$ of EtOH was added.

The reaction mixture was heated to reflux for $6 \mathrm{~h}$ under stirring, allowed to cool to room temperature and was then concentrated in vacuo. To the residue were added $10 \mathrm{~mL}$ of EtOAc and $10 \mathrm{~mL}$ of water. The suspension was filtrated and the filtrate acidified with $1 \mathrm{M} \mathrm{HCl}$ until $\mathrm{pH}=2$. The aqueous layer was extracted three times with EtOAc $(20 \mathrm{~mL})$ and the combined organic phases washed first with water $(10 \mathrm{~mL})$ and 
then with an aqueous saturated $\mathrm{NaCl}$ solution $(10 \mathrm{~mL})$. The organic phase was dried over $\mathrm{MgSO}_{4}$ and the solvent removed under reduced pressure. The [1,2'-binaphthalen]-6'-ol product $\mathbf{3 f}$ was obtained as yellow solid (477.7 $\mathrm{mg}, 1.77 \mathrm{mmol}, 79 \%)$ after column chromatography $\left(\mathrm{SiO}_{2} / n\right.$-pentane:EtOAc 5:1 v/v).

$\mathbf{R}_{\mathbf{f}}=0.42$ (n-pentane:EtOAc 2:1 v/v), UV-active.

m.p.: $146.5-146.9^{\circ} \mathrm{C}$.

${ }^{1} \mathrm{H}$ NMR (400 MHz, DMSO-d $\left.d_{6}\right): \delta=9.79-9.91(\mathrm{br}, 1 \mathrm{H}, \mathrm{Ar}-\mathrm{OH}), 7.99-8.04(\mathrm{~m}, 1 \mathrm{H}, \mathrm{Ar}-H), 7.94-7.99(\mathrm{~m}, 1 \mathrm{H}, \mathrm{Ar}-H)$, 7.80-7.91 (m, 4H, Ar-H), 7.58-7.64 (m, 1H, Ar-H), 7.53-7.58 (m, 1H, Ar-H), 7.45-7.53 (m, 3H, Ar-H), 7.19-7.25 (m, 1H, Ar-H), 7.10-7.18 (m, 1H, Ar-H) ppm.

${ }^{13} \mathrm{C}\left\{{ }^{1} \mathrm{H}\right\}$ NMR (101 MHz, DMSO- $\left.\boldsymbol{d}_{6}\right): \delta=155.7,139.7,134.3,133.8,133.5,131.1,129.7,128.4,128.3,128.2,127.7$, $127.5,127.1,126.3,126.0,125.9,125.6,125.4,119.1,108.6$ ppm.

IR (ATR): $v=3304,3048,2922,2853,2663,2322,2094,1933,1738,1631,1605,1483,1446,1360,1279,1236$, $1201,1152,1020,958,913,867,799,773,674 \mathrm{~cm}^{-1}$.

MS (El, $70 \mathrm{eV}): m / z(\%)=271(20)[M+H]^{+}, 270(100)[M]^{+}, 240(16), 239(47)$.

The NMR data closely match the ones previously reported in the literature. ${ }^{[10]}$

\section{Mechanochemical synthesis of $4 a-f$}

\section{General procedure for solid additive screening (Table S1)}

A $10 \mathrm{~mL} \mathrm{ZrO}$-Mg milling vessel equipped with five milling balls (10 $\mathrm{mm}$ in diameter) of the same material was charged with 2-naphthol (3a, $100.0 \mathrm{mg}, 0.69 \mathrm{mmol}, 1.0$ equiv), vanadinite (1.0 g, 2.44 equiv of the corresponding vanadium content) and a solid additive $(300.0 \mathrm{mg})$. The jar was closed, flushed with oxygen and loaded with 1.0 atm of the gas. The mechanochemical reaction was conducted for $1 \mathrm{~h}$ at $600 \mathrm{rpm}$, for a total of two repetitions with 20 min break in between each one. At the end of this time the remaining pressure was released through one of the lid valves, ca. $3 \mathrm{~mL}$ of $1.0 \mathrm{M} \mathrm{HCl}$ were added and the crude mixture partitioned between water and EtOAc (ca. $3 \mathrm{~mL}$ ). After phase separation, the aqueous phase was extracted three times with EtOAc $(3 \mathrm{~mL})$ and the organic phases combined. Next, the solvent removed under reduced pressure. To the remaining crude solid $1 \mathrm{~mL}$ of $\mathrm{CDCl}_{3}$ was added and the mixture filtered on a shot silica plug directly into an NMR tube. The reported ratio of 4a:3a was calculated based on the signals at 7.95-8.01 ppm (4a) and 7.73-7.81 ppm (3a). 
Table S1 Optimization of reaction conditions for the mechanochemical oxidative coupling of $\mathbf{3 a}$ in the presence of vanadinite. An extract of this table is reported in the manuscript under the name of Table 2.
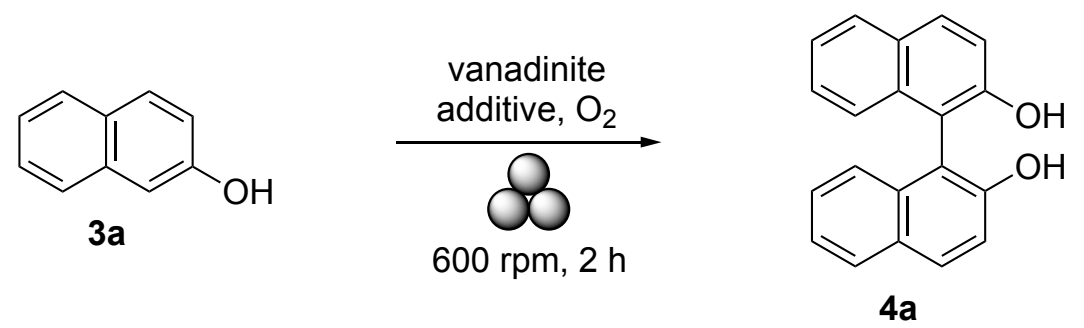

\begin{tabular}{|c|c|c|c|}
\hline Entry & $\mathrm{O}_{2}$ (atm) & Additive & $4 a: 3 a^{a}$ \\
\hline $1^{\mathrm{b}}$ & 1.0 & None & $0: 100$ \\
\hline 2 & 1.0 & None & 1:99 \\
\hline 3 & 1.0 & Glycine & 1:99 \\
\hline 4 & 1.0 & Arginine & 1:99 \\
\hline 5 & 1.0 & Methionine & 1:99 \\
\hline 6 & 1.0 & Histidine & 1:99 \\
\hline 7 & 1.0 & Glutamine & 1:99 \\
\hline 8 & 1.0 & L-Proline & 1:99 \\
\hline 9 & 1.0 & Glutamic acid & 3:97 \\
\hline 10 & 1.0 & Aspartic acid & 8:92 \\
\hline 11 & 1.0 & Tartaric acid & 7:93 \\
\hline 12 & 1.0 & Citric acid & 4:96 \\
\hline 13 & 1.0 & DPA & $24: 76$ \\
\hline 14 & 4.0 & DPA & $33: 67$ \\
\hline 15 & 4.0 & DPA, LAG (MeOH $\eta=0.5)^{c}$ & $87: 13$ \\
\hline $16^{\mathrm{d}}$ & 4.0 & DPA, LAG $(\mathrm{MeOH} \eta=0.5)$ & $89: 11$ \\
\hline $17^{e}$ & 4.0 & DPA, LAG (MeOH $\eta=0.5)$ & $68: 32$ \\
\hline
\end{tabular}

Reaction conditions: $3 a$ (100.0 $\mathrm{mg} ; 0.69 \mathrm{mmol})$, vanadinite ore (1.0 g; equivalent to $1.70 \mathrm{mmol}$ of vanadium) and additive $(300.0 \mathrm{mg})$ were milled in a planetary ball mill under an $\mathrm{O}_{2}$ atmosphere in a $20 \mathrm{~mL} \mathrm{ZrO}-\mathrm{Mg}$ milling jar with five $10 \mathrm{~mm} \varnothing$ balls of the same material for $2 \mathrm{~h}$ at $600 \mathrm{rpm}(1 \mathrm{~h} \times 2 ; 20 \mathrm{~min}$ pause after each milling cycle). a Determined by ${ }^{1} \mathrm{H}$ NMR spectroscopy. ${ }^{\mathrm{b}}$ No vanadinite was added. ${ }^{\mathrm{C}} \eta$ is the volume of solvent (in $\mu \mathrm{L}$ ) divided by the total weight of the solid reactants (in $\mathrm{mg}$ ). ${ }^{d}$ Vanadinite $500.0 \mathrm{mg}$ ( $0.85 \mathrm{mmol}$ of vanadium) and DPA (150.0 $\mathrm{mg}, 0.90 \mathrm{mmol}$ ) were used. ${ }^{e}$ Vanadinite $250.0 \mathrm{mg}(0.42 \mathrm{mmol}$ of vanadium) and DPA ( $75.0 \mathrm{mg}, 0.45 \mathrm{mmol})$ were used.

\section{General procedure for LAG screening (Table 3)}

A $10 \mathrm{~mL} \mathrm{ZrO} 2-\mathrm{Mg}$ milling vessel equipped with five milling balls (10 $\mathrm{mm}$ in diameter) of the same material was charged with 2-naphthol (3a, $100.0 \mathrm{mg}, 0.69 \mathrm{mmol}, 1.0$ equiv), vanadinite $(250.0 \mathrm{mg}, 0.6$ equiv of the corresponding vanadium content), pyridine-2,6-dicarboxylic acid $(75.0 \mathrm{mg}, 0.45 \mathrm{mmol}, 0.7$ equiv) and a liquid additive $(\eta=0.05-0.5 \mu \mathrm{L} / \mathrm{mg})$. The jar was closed, flushed with oxygen, loaded with $4.0 \mathrm{~atm}$ of the gas. The mechanochemical reaction was conducted for $1 \mathrm{~h}$ at $600 \mathrm{rpm}$, for a total of two repetitions with 20 min break in between each one. At the end of this time the remaining pressure was released through one of the lid valves, ca. $3 \mathrm{~mL}$ of $1.0 \mathrm{M} \mathrm{HCl}$ were added and the crude mixture partitioned between water and EtOAc (ca. $50 \mathrm{~mL}$ ). The biphasic mixture was filtrated on a short silica plug and the organic phase separated. The water phase was extracted three times with EtOAc $(10 \mathrm{~mL})$, the organic phases combined, and the solvent evaporated under reduced pressure. To the remaining crude solid was added 1,3,5-trimethoxybenzene as internal standard and ca. 
$3 \mathrm{~mL}$ of $\mathrm{CDCl}_{3}$. The mixture filtered through a short silica plug directly into an NMR tube. The reported yield was calculated based on the signals at 7.95-8.01 ppm (4s) and 6.11-6.19 ppm (internal standard).

\section{General procedure for the mechanochemical synthesis of 1,1'-bi-2-naphthols (4a-f) with vanadinite}

A $10 \mathrm{~mL} \mathrm{ZrO}$-Mg milling vessel equipped with five milling balls (10 $\mathrm{mm}$ in diameter) of the same material was charged with 2-naphthol (3a) (100.0 mg, $0.69 \mathrm{mmol}, 1.0$ equiv), vanadinite $(250.0 \mathrm{mg}, 0.6$ equiv of the corresponding vanadium content), pyridine-2,6-dicarboxylic acid (70.9 mg, $0.42 \mathrm{mmol}, 0.6$ equiv) and $\mathrm{MeOH}$ $(21.0 \mu \mathrm{L}, \eta=0.05 \mu \mathrm{L} / \mathrm{mg})$. The jar was closed, flushed with oxygen, loaded with 4.0 atm of the gas. The mechanochemical reaction was conducted for $1 \mathrm{~h}$ at $600 \mathrm{rpm}$, for a total of eight repetitions with 20 min break in between each cycle. At the end of this time the remaining pressure was released through one of the lid valves, ca. $3 \mathrm{~mL}$ of $1.0 \mathrm{M} \mathrm{HCl}$ were added and the crude mixture partitioned between water and EtOAc (ca. $50 \mathrm{~mL}$ ). The biphasic mixture was filtrated through a short silica plug and the organic phase separated. The water phase was extracted three times with EtOAc $(10 \mathrm{~mL})$, the organic phases combined, and the solvent evaporated under reduced pressure. The [1,1'-binaphthalene]-2,2'-diol (4a) was obtained as pale yellow solid $(85.6 \mathrm{mg}, 0.30 \mathrm{mmol}$, $86 \%$ yield) after column chromatography $\left(\mathrm{SiO}_{2} / n\right.$-pentane:EtOAc 6:1 $\left.\mathrm{v} / \mathrm{v}\right)$.

\section{[1,1'-Binaphthalene]-2,2'-diol (4a)}<smiles>Oc1ccc2ccccc2c1-c1c(O)ccc2ccccc12</smiles>

$\mathbf{R}_{\mathbf{f}}=0.60(n$-Pentane:EtOAc 2.5:1 v/v), UV-active.

m.p.: $217.9-218.5^{\circ} \mathrm{C}$.

${ }^{1} \mathbf{H}$ NMR (400 MHz, $\left.\mathrm{CDCl}_{3}\right): \delta=7.93-8.02(\mathrm{~m}, 2 \mathrm{H}, \mathrm{Ar}-H), 7.85-7.93(\mathrm{~m}, 2 \mathrm{H}, \mathrm{Ar}-\mathrm{H}), 7.34-7.42(\mathrm{~m}, 4 \mathrm{H}, \mathrm{Ar}-\mathrm{H})$, 7.28-7.34 (m, 2H, Ar-H), 7.12-7.20 (m, 2H, Ar-H), 5.01-5.14 (br, 2H, 2xAr-OH) ppm.

${ }^{13} \mathrm{C}\left\{{ }^{1} \mathrm{H}\right\}$ NMR (101 MHz, $\left.\mathrm{CDCl}_{3}\right): \delta=152.9,135.5,131.5,129.6,128.5,127.6,124.3,124.2,117.9,111.0 \mathrm{ppm}$.

IR (ATR): $v=3484,3399,3048,3232,2084,1917,1617,1592,1511,1466,1379,1320,1272,1252,1212,1170$, $1142,958,819,749,666 \mathrm{~cm}^{-1}$.

MS (EI, $70 \mathrm{eV}): m / z(\%)=287(14)[M+H]^{+}, 286(100)[M]^{+}, 257(23), 239(23), 120(27)$.

The NMR data closely match the ones previously reported in the literature. ${ }^{[11]}$ 


\section{7,7'-Dimethoxy-[1,1'-binaphthalene]-2,2'-diol (4b)}<smiles>COc1ccc2ccc(O)c(-c3c(O)ccc4ccc(OC)cc34)c2c1</smiles>

pentane.

The title compound was synthesized using the general procedure stated above.

7-Methoxy-2-naphthol (121.9 mg, $0.70 \mathrm{mmol}, 1.0 \mathrm{eq}$ ), vanadinite $(252.2 \mathrm{mg}, 0.6$ equiv of the corresponding vanadium content), pyridine-2,6-dicarboxylic acid ( $71.5 \mathrm{mg}, 0.42$ mmol, 0.6 equiv) and $\mathrm{MeOH}(22.3 \mu \mathrm{L}, \eta=0.05 \mu \mathrm{L} / \mathrm{mg})$ were used.

Product $4 \mathbf{b}$ was obtained as a pale yellow solid ( $116.3 \mathrm{mg}, 0.34 \mathrm{mmol}, 96 \%)$ after column chromatography $\left(\mathrm{SiO}_{2} / n\right.$-pentane:EtOAc 3:1 $\left.\mathrm{v} / \mathrm{v}\right)$ and washing with warm distilled $n$ -

$\mathbf{R}_{\mathbf{f}}=0.18(n$-pentane:EtOAc 2:1 $\mathrm{v} / \mathrm{v})$, UV-active.

m.p.: $150.8-151.2^{\circ} \mathrm{C}$.

${ }^{1} \mathrm{H}$ NMR (400 MHz, $\left.\mathrm{CDCl}_{3}\right): \delta=7.83-7.92(\mathrm{~m}, 2 \mathrm{H}, \mathrm{Ar}-H)$, 7.74-7.82 (m, 2H, Ar-H), 7.25-7.19 (m, 2H, Ar-H), 7.00$7.07(\mathrm{~m}, 2 \mathrm{H}, \mathrm{Ar}-\mathrm{H}), 6.45-6.53(\mathrm{~m}, 2 \mathrm{H}, \mathrm{Ar}-\mathrm{H}), 4.97-5.11(\mathrm{br}, 2 \mathrm{H}, 2 \times \mathrm{Ar}-\mathrm{OH}) \mathrm{ppm}$.

${ }^{13} \mathrm{C}\left\{{ }^{1} \mathrm{H}\right\}$ NMR $\left(101 \mathrm{MHz}, \mathrm{CDCl}_{3}\right): \delta=159.2,153.5,134.8,131.3,130.1,124.9,116.2,115.2,110.2,103.3,55.3 \mathrm{ppm}$.

IR (ATR): $v=3376,3004,2933,2834,2318,2112,2077,1906,1742,1620,1510,1456,1431,1377,1333,1267$, $1215,1145,1068,1028,1000,955,871,825,695 \mathrm{~cm}^{-1}$.

MS (El, $70 \mathrm{eV}): m / z(\%)=347(13)[M+H]^{+}, 346(100)[M]^{+}$.

The NMR data closely match the ones previously reported in the literature. ${ }^{[11]}$

\section{6,6'-Dibromo-[1,1'-binaphthalene]-2,2'-diol (4c)}

The title compound was synthesized using the general procedure stated above.<smiles>Oc1ccc2cc(Br)ccc2c1-c1c(O)ccc2cc(Br)ccc12</smiles>

6-Bromo-2-naphthol (156.1 mg, $0.7 \mathrm{mmol}, 1.0$ equiv), vanadinite ( $252.5 \mathrm{mg}, 0.6$ equiv of the corresponding vanadium content), pyridine-2,6-dicarboxylic acid (71.5 mg, 0.42 mmol, 0.6 equiv) and $\mathrm{MeOH}(24.0 \mu \mathrm{L}, \eta=0.05 \mu \mathrm{L} / \mathrm{mg})$ were used. Product 4c was obtained as a pale yellow solid ( $82.0 \mathrm{mg}, 0.18 \mathrm{mmol}, 53 \%)$ after column chromatography $\left(\mathrm{SiO}_{2} / n\right.$-Pentane:EtOAc 3:1 v/v) and washing with warm distilled $n$-pentane.

$\mathbf{R}_{\mathbf{f}}=0.13$ ( $n$-Pentane:EtOAc 2:1 v/v), UV-active.

m.p.: $189.3-191.0^{\circ} \mathrm{C}$.

${ }^{1} \mathrm{H}$ NMR $\left(400 \mathrm{MHz}, \mathrm{CDCl}_{3}\right): \delta=8.02-8.08(\mathrm{~m}, 2 \mathrm{H}, \mathrm{Ar}-H), 7.94-7.85(\mathrm{~m}, 2 \mathrm{H}, \mathrm{Ar}-H), 7.33-7.44(\mathrm{~m}, 4 \mathrm{H}, \mathrm{Ar}-H), 6.91-$ $7.01(\mathrm{~m}, 2 \mathrm{H}, \mathrm{Ar}-\mathrm{H}), 4.96-5.05(\mathrm{br}, 2 \mathrm{H}, 2 \mathrm{Ar}-\mathrm{OH}) \mathrm{ppm}$.

${ }^{13} \mathrm{C}\left\{{ }^{1} \mathrm{H}\right\}$ NMR $\left(101 \mathrm{MHz}, \mathrm{CDCl}_{3}\right): \delta=153.1,132.0,131.0,130.9,130.7,130.6,126.0,119.1,118.2,110.7 \mathrm{ppm}$. 
IR (ATR): $v=3465,3409,3255,2921,2852,2658,2324,2108,1909,1762,1583,1493,1409,1379,1316,1262$, $1212,1168,1146,1066,961,924,875,812,770,670 \mathrm{~cm}^{-1}$.

MS (El, $70 \mathrm{eV}): m / z(\%)=446(45)[M+2 \mathrm{H}]^{+}, 444(100)[M]^{+}, 442(76)[M-2 \mathrm{H}]^{+}, 256(31), 255(31), 226(36), 142$ (31), $118(23), 113(23)$.

The NMR data closely match the ones previously reported in the literature. ${ }^{[11]}$

\section{3,3'-Dibromo-[1,1'-binaphthalene]-2,2'-diol (4d)}<smiles>Oc1c(Br)cc2ccccc2c1-c1c(O)c(Br)cc2ccccc12</smiles>

The title compound was synthesized using the general procedure stated above.

3-Bromo-2-naphthol (156.1 mg, $0.7 \mathrm{mmol}, 1.0$ equiv), vanadinite ( $252.5 \mathrm{mg}, 0.6$ equiv of the corresponding vanadium content), pyridine-2,6-dicarboxylic acid ( $71.5 \mathrm{mg}, 0.42 \mathrm{mmol}, 0.6$ equiv) and $\mathrm{MeOH}(24.0 \mu \mathrm{L}, \eta=0.05 \mu \mathrm{L} / \mathrm{mg}$ ) were used. Product $\mathbf{4 d}$ was obtained as a pale yellow solid $(56.7 \mathrm{mg}, 0.13 \mathrm{mmol}, 36 \%)$ after column chromatography $\left(\mathrm{SiO}_{2} / \mathrm{n}\right.$ pentane:EtOAc 6:1 $\mathrm{v} / \mathrm{v}$ ) and washing with warm distilled $n$-pentane.

$\mathbf{R}_{\mathbf{f}}=0.65$ (n-pentane:EtOAc 3:1 v/v), UV-active.

m.p.: $286.7-287.3^{\circ} \mathrm{C}$.

${ }^{1} \mathrm{H}$ NMR (400 MHz, $\left.\mathrm{CDCl}_{3}\right): \delta=8.21-8.30(\mathrm{~m}, 2 \mathrm{H}, \mathrm{Ar}-\mathrm{H}), 7.78-7.87(\mathrm{~m}, 2 \mathrm{H}, \mathrm{Ar}-\mathrm{H}), 7.35-7.42(\mathrm{~m}, 2 \mathrm{H}, \mathrm{Ar}-\mathrm{H}), 7.28-$ $7.34(\mathrm{~m}, 2 \mathrm{H}, \mathrm{Ar}-\mathrm{H}), 7.05-7.13(\mathrm{~m}, 2 \mathrm{H}, \mathrm{Ar}-\mathrm{H}), 5.49-5.58(\mathrm{br}, 2 \mathrm{H}, 2 \times \mathrm{Ar}-\mathrm{OH}) \mathrm{ppm}$.

${ }^{13} \mathrm{C}\left\{{ }^{1} \mathrm{H}\right\}$ NMR $\left(101 \mathrm{MHz}, \mathrm{CDCl}_{3}\right): \delta=148.2,132.9,129.9,127.8,127.6,125.0,124.8,114.8,112.4 \mathrm{ppm}$.

IR (ATR): $v=3486,3151,3095,2924,2668,2324,2084,1910,1837,1733,1574,1495,1419,1376,1314,1216$, $1143,1002,929,876,855,791,748,685 \mathrm{~cm}^{-1}$.

MS (El, $70 \mathrm{eV}): m / z(\%)=446(45)[M+2 \mathrm{H}]^{+}, 444(100)[M]^{+}, 442(76)[M-2 \mathrm{H}]^{+}, 256(20), 255(33), 226(44), 142$ (31), 133 (22), $113(30)$.

The NMR data closely match the ones previously reported in the literature. ${ }^{[12]}$ 


\section{6,6'-Diphenyl-[1,1'-binaphthalene]-2,2'-diol (4e)}

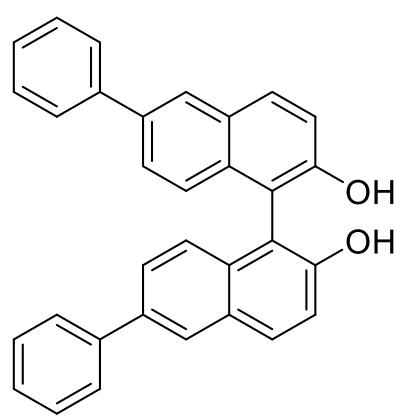

The title compound was synthesized using the general procedure stated above. 6-Phenylnaphthalen-2-ol 3e (154.2 mg, $0.7 \mathrm{mmol}, 1.0$ equiv), vanadinite ( $252.5 \mathrm{mg}$, 0.6 equiv of the corresponding vanadium content), pyridine-2,6-dicarboxylic acid (71.5 mg, $0.42 \mathrm{mmol}, 0.6$ equiv) and $\mathrm{MeOH}(23.9 \mu \mathrm{L}, \eta=0.05 \mu \mathrm{L} / \mathrm{mg}$ ) were used. Product $4 \mathrm{e}$ was obtained as a pale yellow solid (111.1 $\mathrm{mg}, 0.25 \mathrm{mmol}, 72 \%)$ after column chromatography $\left(\mathrm{SiO}_{2} / n\right.$-pentane:EtOAc 7:1 v/v).

$\mathbf{R}_{\mathbf{f}}=0.45$ ( $n$-Pentane:EtOAc 2:1 v/v), UV-active.

m.p.: $171.7-172.6^{\circ} \mathrm{C}$.

${ }^{1} \mathrm{H}$ NMR (400 MHz, $\left.\mathrm{CDCl}_{3}\right): \delta=8.09-8.15(\mathrm{~m}, 2 \mathrm{H}, \mathrm{Ar}-\mathrm{H}), 8.01-8.09(\mathrm{~m}, 2 \mathrm{H}, \mathrm{Ar}-\mathrm{H}), 7.65-7.63(\mathrm{~m}, 4 \mathrm{H}, \mathrm{Ar}-\mathrm{H}), 7.56-$ $7.64(\mathrm{~m}, 2 \mathrm{H}, \mathrm{Ar}-H), 7.53-7.41(\mathrm{~m}, 6 \mathrm{H}, \mathrm{Ar}-H), 7.33-7.41(\mathrm{~m}, 2 \mathrm{H}, \mathrm{Ar}-H), 7.25-7.32(\mathrm{~m}, 2 \mathrm{H}, \mathrm{Ar}-H), 5.07-5.18(\mathrm{~m}$, $2 \mathrm{H}, 2 \times \mathrm{Ar}-\mathrm{OH}) \mathrm{ppm}$.

${ }^{13} \mathrm{C}\left\{{ }^{1} \mathrm{H}\right\}$ NMR (101 MHz, $\left.\mathrm{CDCl}_{3}\right): \delta=153.0,140.9,137.1,132.7,131.9,129.9,129.0,127.4,127.4,127.3,126.5$, 124.9, 118.4, 110.9 ppm.

IR (ATR): $v=3463,3396,3027,2923,2320,2108,1989,1908,1717,1593,1491,1446,1383,1352,1281,1213$, $1148,1074,1022,964,934,885,813,752,692 \mathrm{~cm}^{-1}$.

MS (EI, 70 eV): $m / z(\%)=439(31)[M+H]^{+}, 438(100)[M]^{+}, 77(15)$

The NMR data closely match the ones previously reported in the literature. ${ }^{[13]}$

\section{[1,2':5',1":6",1'"-Quaternaphthalene]-2",6'-diol (4f)}<smiles>Oc1ccc2cc(-c3cccc4ccccc34)ccc2c1-c1c(O)ccc2cc(-c3cccc4ccccc34)ccc12</smiles>

The title compound was synthesized using the general procedure stated above. 1,2'-Binaphthalen-6'-ol 3f (189.2 mg, 0.7 mmol, 1.0 equiv), vanadinite ( $252.5 \mathrm{mg}$, 0.6 equiv of the corresponding vanadium content), pyridine-2,6-dicarboxylic acid (71.5 mg, $0.42 \mathrm{mmol}, 0.6$ equiv) and $\mathrm{MeOH}(25.6 \mu \mathrm{L}, \eta=0.05 \mu \mathrm{L} / \mathrm{mg}$ ) were used. Product $\mathbf{4 f}$ was obtained as a brown solid $(56.9 \mathrm{mg}, 0.11 \mathrm{mmol}, 30 \%)$ after column chromatography $\left(\mathrm{SiO}_{2} / n\right.$-pentane:EtOAc 7:1 v/v).

$\mathbf{R}_{\mathbf{f}}=0.18$ ( $n$-pentane:EtOAc 2:1 v/v), UV-active.

m.p.: $166.2-167.8^{\circ} \mathrm{C}$. 
${ }^{1} \mathrm{H}$ NMR (400 MHz, $\left.\mathrm{CDCl}_{3}\right): \delta=8.04-8.08(\mathrm{~m}, 4 \mathrm{H}, \mathrm{Ar}-\mathrm{H}), 7.88-7.99(\mathrm{~m}, 6 \mathrm{H}, \mathrm{Ar}-H), 7.47-7.59(\mathrm{~m}, 9 \mathrm{H}, \mathrm{Ar}-\mathrm{H}), 7.38-$ $7.45(\mathrm{~m}, 4 \mathrm{H}, \mathrm{Ar}-\mathrm{H}), 5.11-5.28(\mathrm{br}, 2 \mathrm{H}, 2 \times \mathrm{Ar}-\mathrm{OH}) \mathrm{ppm}$.

${ }^{13} \mathrm{C}\left\{{ }^{1} \mathrm{H}\right\}$ NMR $\left(101 \mathrm{MHz}, \mathrm{CDCl}_{3}\right): \delta=153.2,140.0,136.8,134.0,132.7,131.8,130.3,129.7,129.5,128.5,127.9$, $127.4,126.3,126.2,126.0,125.6,124.2,118.4,111.0$ ppm.

IR (ATR): $v=3857,3510,3048,2924,2324,2113,2068,1925,1710,1591,1476,1382,1349,1280,1145,932$, $895,777,689 \mathrm{~cm}^{-1}$.

MS (El, $70 \mathrm{eV}): m / z(\%)=540(1)[M+2 \mathrm{H}]^{+}, 539[\mathrm{M}+\mathrm{H}]^{+}, 538[\mathrm{M}]^{+}$.

The NMR data closely match the ones previously reported in the literature. ${ }^{[14]}$

\section{References}

[1] Mestrelab Research S.L. MestReNova, 2018, Version 12.0.1-20560.

[2] Fulmer, G. R.; Miller, A. J. M.; Sherden, N. H.; Gottlieb, H. E.; Nudelman, A.; Stoltz, B. M.; Bercaw, J. E. Goldberg, K. I. NMR Chemical Shifts of Trace Impurities: Common Laboratory Solvents, Organics, and Gases in Deuterated Solvents Relevant to the Organometallic Chemist. Organometallics 2019, 29, 2176-2179. DOI: 10.1021/om100106e.

[3] Groom, C. R.; Bruno, I. J.; Lightfoot, M. P.; Ward, S. C. The Cambridge Structural Database. Acta Cryst. 2016, B72, 171-179. DOI: 10.1107/S2052520616005369.

[4] Sweeney, J. B.; Ball, A. K.; Lawrence, P. A.; Sinclair, M. C.; Smith, L. J. A Simple, Broad-Scope Nickel(0) Precatalyst System for the Direct Amination of Allyl Alcohols. Angew. Chem. Int. Ed. 2018, 57, 10202-10206. DOI: 10.1002/anie.201805611.

[5] Clark, A. J.; Collis, A. E. C.; Fox, D. J.; Halliwell, L. L.; James, N.; O’Reilly, R. K.; Parekh, H.; Ross, A.; Sellars, A. B.; Willcock, H.; Wilson, P. Atom-Transfer Cyclization with $\mathrm{CuSO}_{4} / \mathrm{KBH}_{4}$ : A Formal "Activators Generated by Electron Transfer" Process Also Applicable to Atom-Transfer Polymerization. J. Org. Chem., 2012, 77, 6778-6788. DOI: 10.1021/jo301429a.

[6] Poornachandran, M.; Raghunathan, R. Synthesis of pyrrolo[3,4-b]pyrroles and perhydrothiazolo[3',4'-2,3]pyrrolo[4,5-c]pyrroles. Tetrahedron 2008, 64, 6461-6474. DOI: 10.1016/j.tet.2008.04.063.

[7] Jahng, Y.; Kim, J. I. Aza-analogue of mevinolin: Synthesis of substituted octahydroisoquinoline, the bottom half of aza-analogue of mevinolin. Arch. Pharm. Res. 1994, 17, 104-108. DOI: 10.1007/BF02974232.

[8] Blid, J.; Brandt, P.; Somfai, P. Lewis Acid Mediated [2,3]-Sigmatropic Rearrangement of Allylic $\alpha$ Amino Amides. J. Org. Chem. 2004, 69, 3043-3049. DOI: 10.1021/jo035618g. 
[9] Guan, B. T.; Wang, Y. B.; Li, J.; Yu, D. G.; Shi, Z. J. Biaryl Construction via Ni-Catalyzed C-O Activation of Phenolic Carboxylates. J. Am. Chem. Soc. 2008, 130, 14468-14470. DOI: 10.1021/ja8056503.

[10] Xu, Z. J.; Zheng, H.; Hu, B.; Liu, X.; Lin, L.; Feng, X. Chiral cobalt(II) complex catalyzed Friedel-Crafts aromatization for the synthesis of axially chiral biaryldiols. Chem. Comm. 2017, 53, 9741-9744. DOI: 10.1039/C7CC05266A.

[11] Fang, J.; Peng, Z.; Yang, Y.; Wang, J.; Guo, J.; Gong, H. Graphene-Oxide-Promoted Direct Dehydrogenative Coupling Reaction of Aromatics. Asian J. Org. Chem. 2018, 7, 355-358. DOI: 10.1002/ajoc.201700673.

[12] Xu, Y.; Clarkson, G. C.; Docherty, G.; North, C. L.; Woodward, G.; Wills, M. Ruthenium(II) Complexes of Monodonor Ligands: Efficient Reagents for Asymmetric Ketone Hydrogenation. J. Org. Chem. 2015, 70, 8079-8087. DOI: 10.1021/jo051176s.

[13] Li, B; Chiu, P. A Protecting-Group-Free Route to Chiral BINOL-Phosphoric Acids. Eur. J. Org. Chem. 2011, 3932-3937. DOI: 10.1002/ejoc.201100328.

[14] Taniguchi, T.; Fukuba, T. A.; Nakatsuka, S.; Hayase, S.; Kawatsura, M.; Uno, H.; Itoh, T. LinkerOriented Design of Binaphthol Derivatives for Optical Resolution Using Lipase-Catalyzed Reaction. J. Org. Chem. 2008, 73, 3875-3884. DOI: 10.1021/jo800351h. 


\section{NMR spectra}

\section{$\mathrm{N}$-Allyl-N-benzylamine (S1a)}

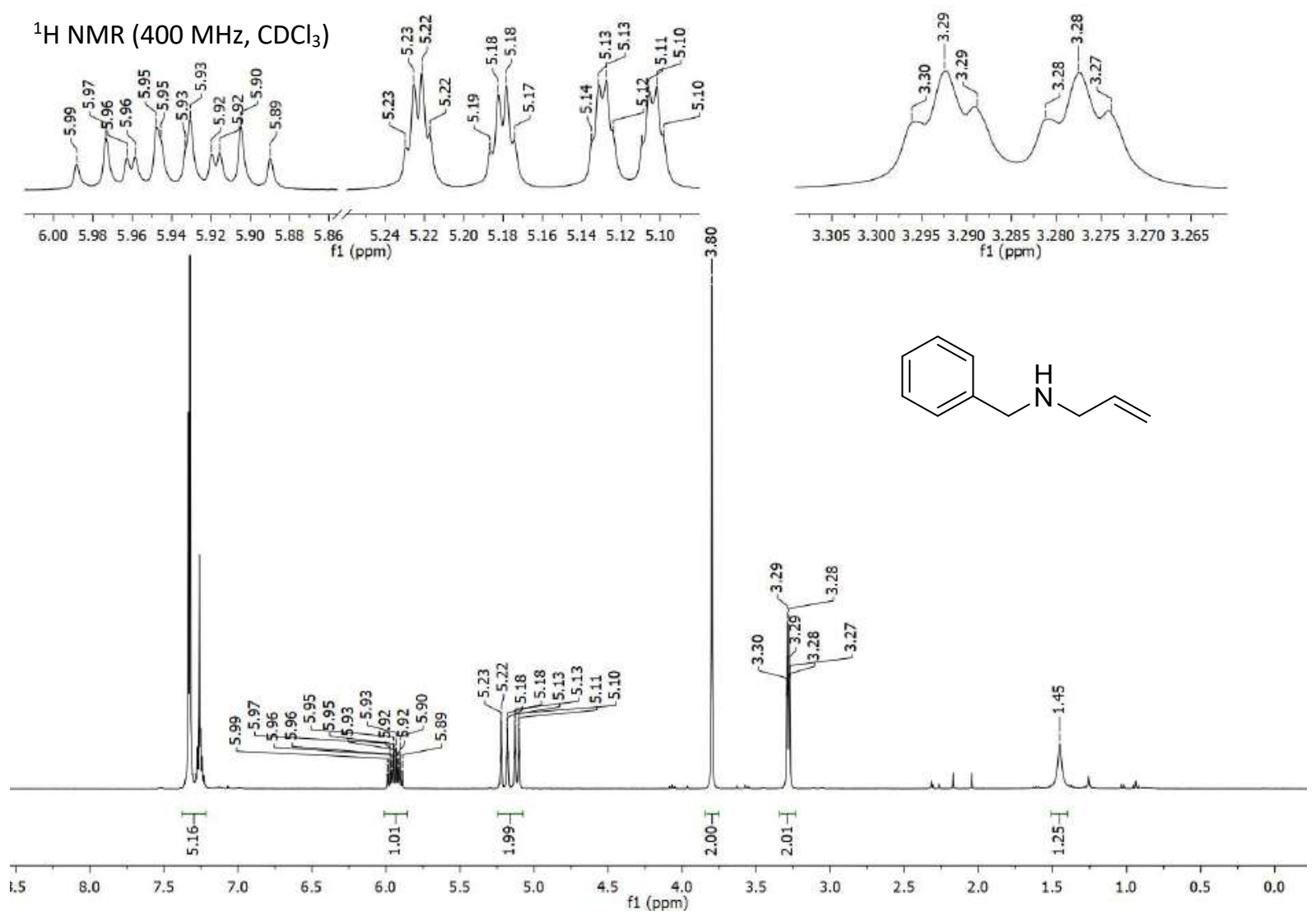




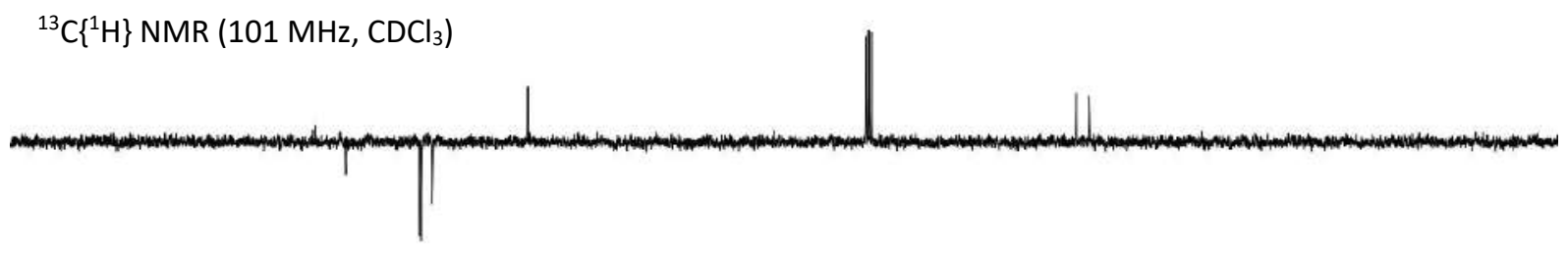<smiles>C=CCNCc1ccccc1</smiles>

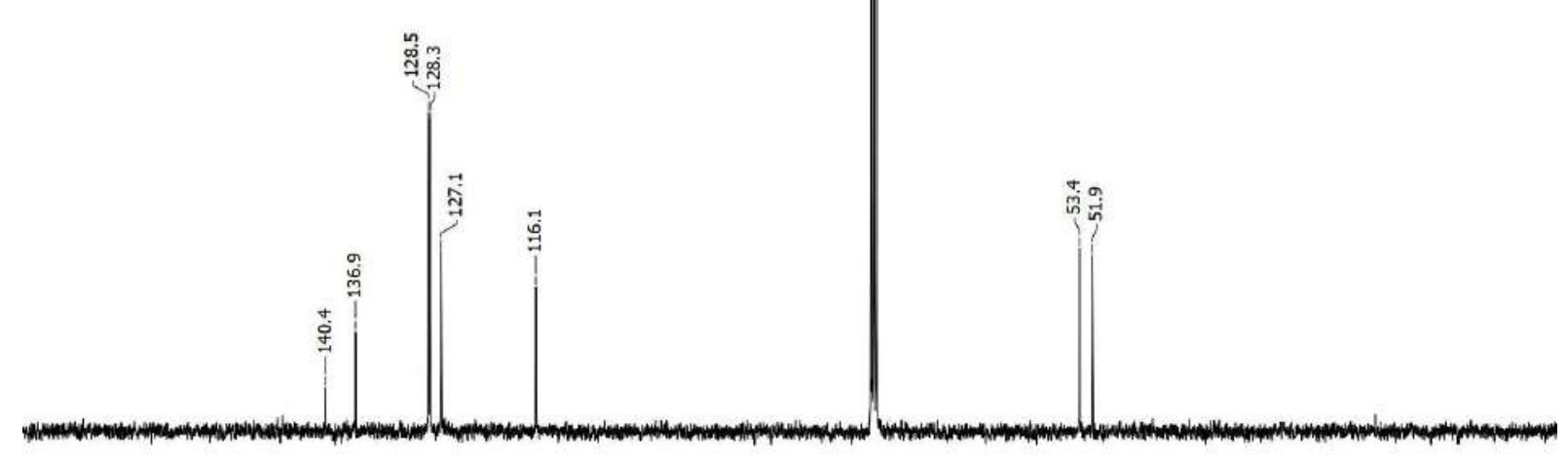

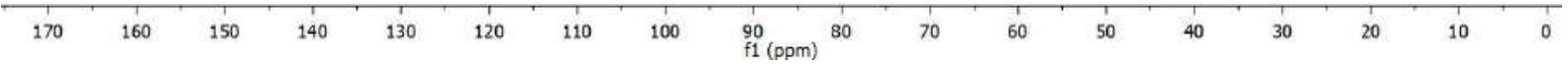


N-Allyl-N-benzyl-2-bromo-2-methylpropanamide (1a)

${ }^{1} \mathrm{H}$ NMR (400 MHz, Toluene- $d_{8}, 95^{\circ} \mathrm{C}$ )<smiles>C=CCN(Cc1ccccc1)C(=O)C(C)(C)Br</smiles>

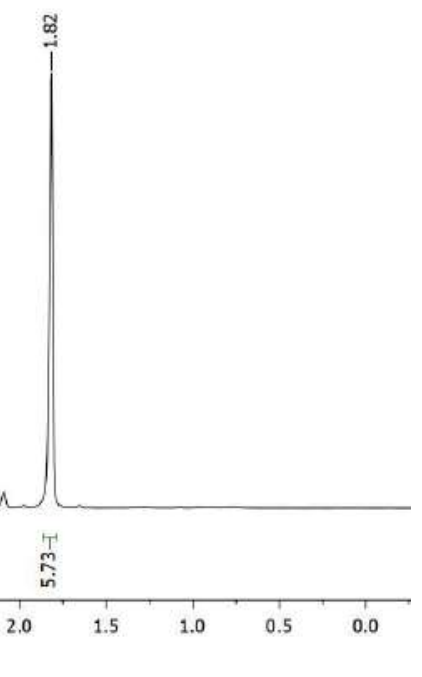

${ }^{13} \mathrm{C}\left\{{ }^{1} \mathrm{H}\right\}$ NMR $\left(101 \mathrm{MHz}\right.$, Toluene- $\left.d_{8}, 95^{\circ} \mathrm{C}\right)$
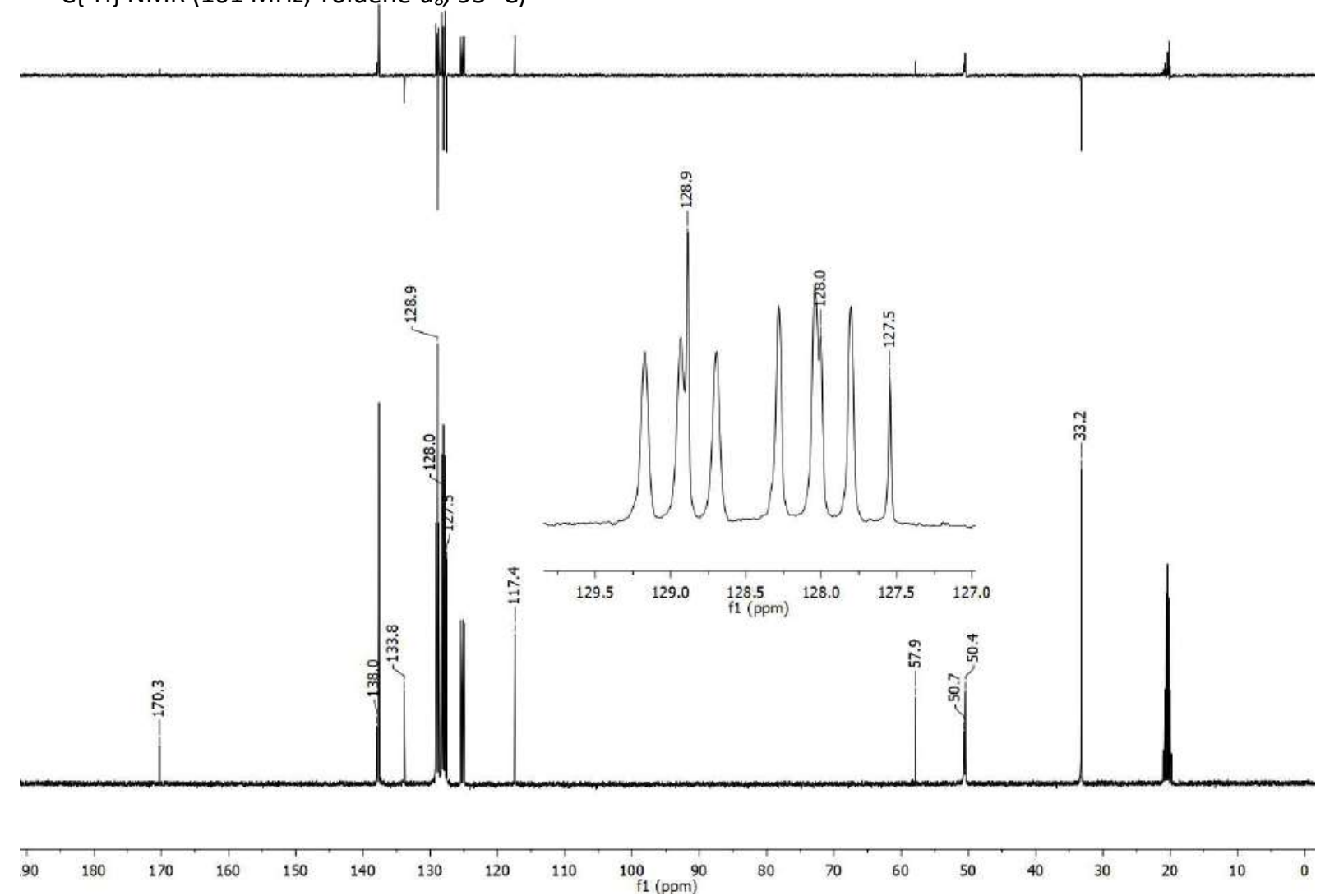
N-Allyl-2-bromo-N-2-dimethylpropanamide (1b)

${ }^{1} \mathrm{H}$ NMR (400 MHz, Toluene- $d_{8}, 95^{\circ} \mathrm{C}$ )<smiles>C=CCN(C)C(=O)C(C)(C)Br</smiles>
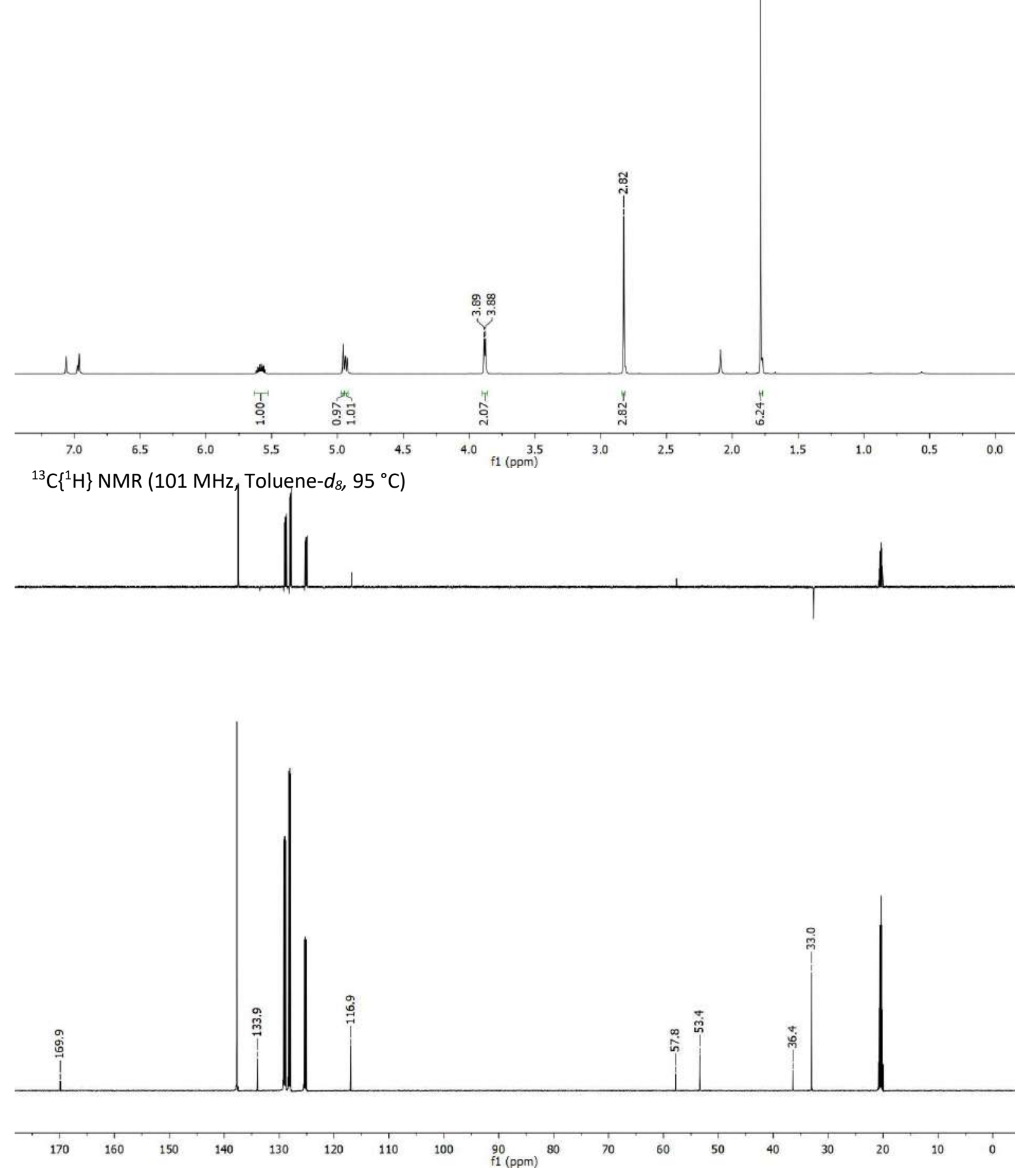
N-Allyl-4-methylbenzenesulfonamide (S1c)

${ }^{1} \mathrm{H}$ NMR $\left(600 \mathrm{MHz}, \mathrm{CDCl}_{3}\right)$<smiles>C=CCNS(=O)(=O)c1ccc(C)cc1</smiles>

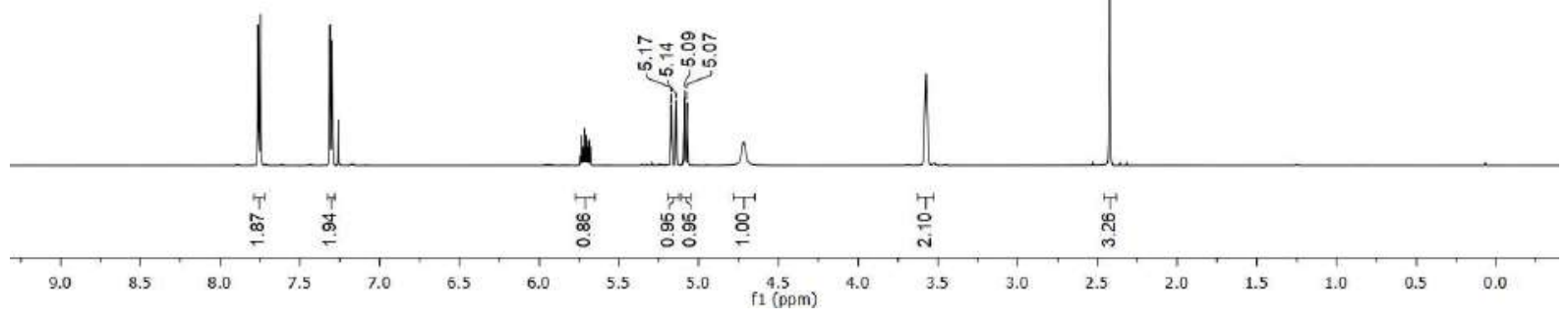

${ }^{13} \mathrm{C}\left\{{ }^{1} \mathrm{H}\right\}$ NMR (151 MHz, $\left.\mathrm{CDCl}_{3}\right)$
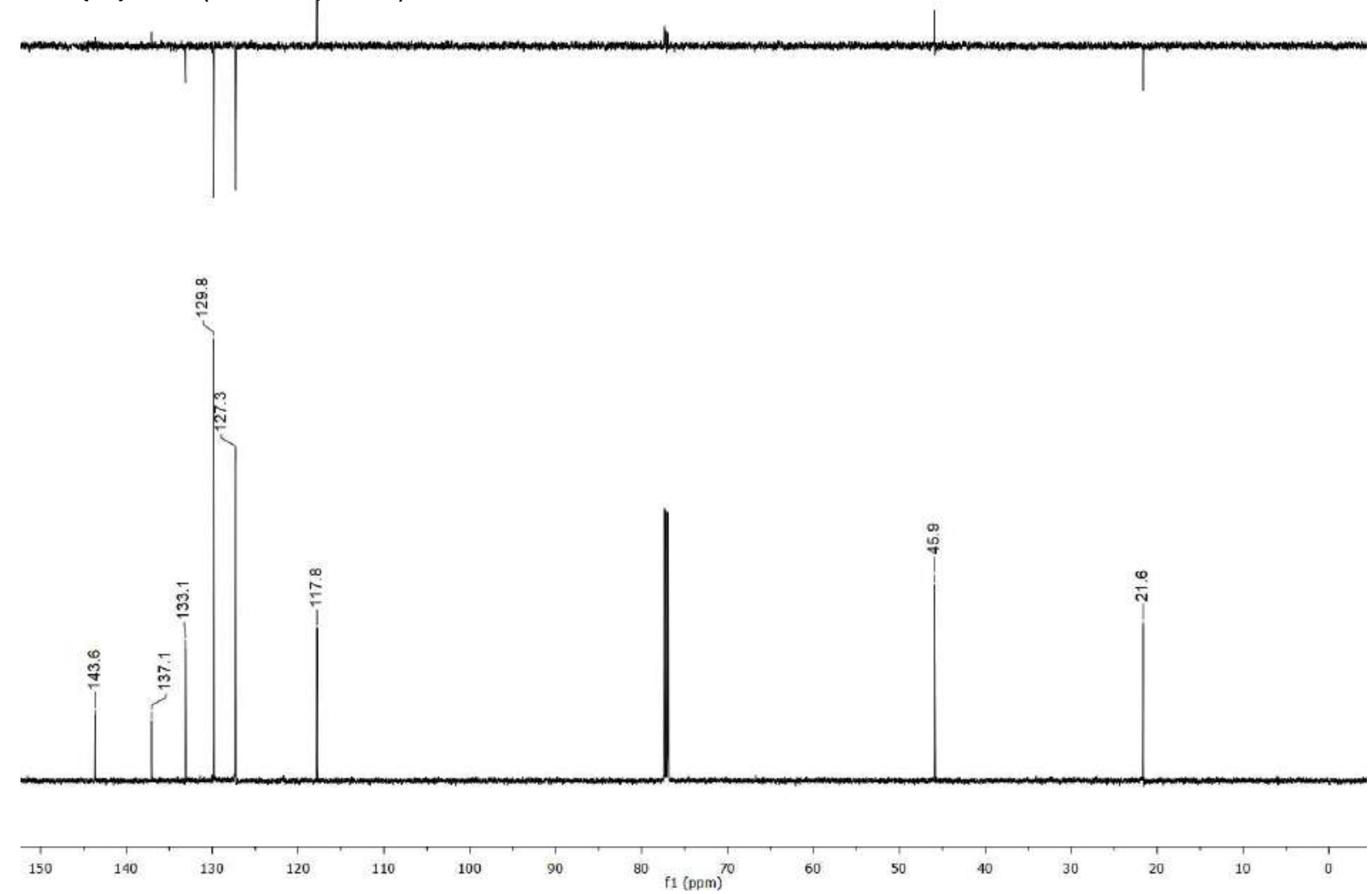
N-Allyl-2-bromo-2-methyl-N-tosylpropanamide (1c)

${ }^{1} \mathrm{H}$ NMR (600 MHz, CDCl ${ }_{3}$ )
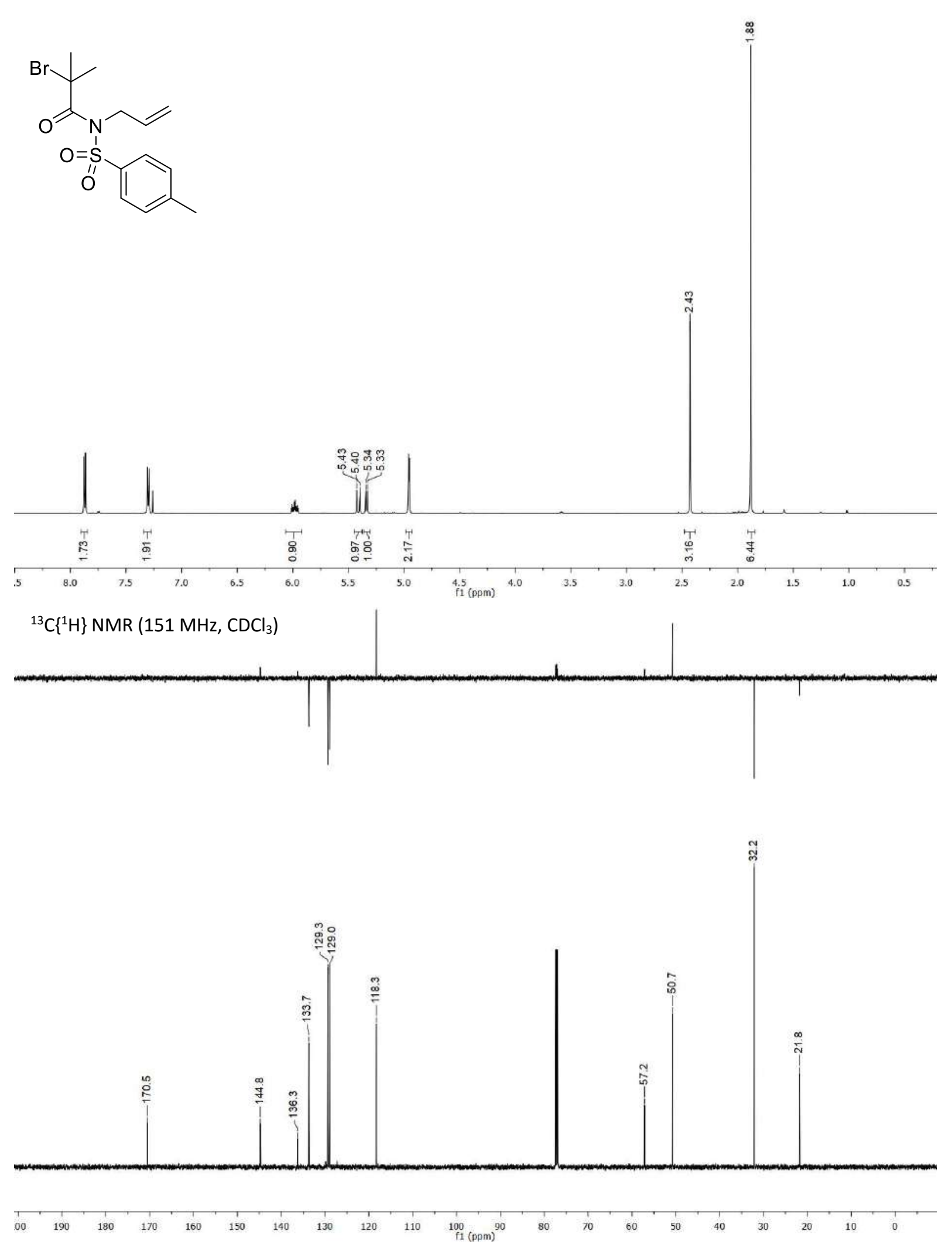
$N-(2-M e t h a l l y l) b e n z y l a m i n e(S 1 d)$

${ }^{1} \mathrm{H}$ NMR $\left(400 \mathrm{MHz}, \mathrm{CDCl}_{3}\right)$

(

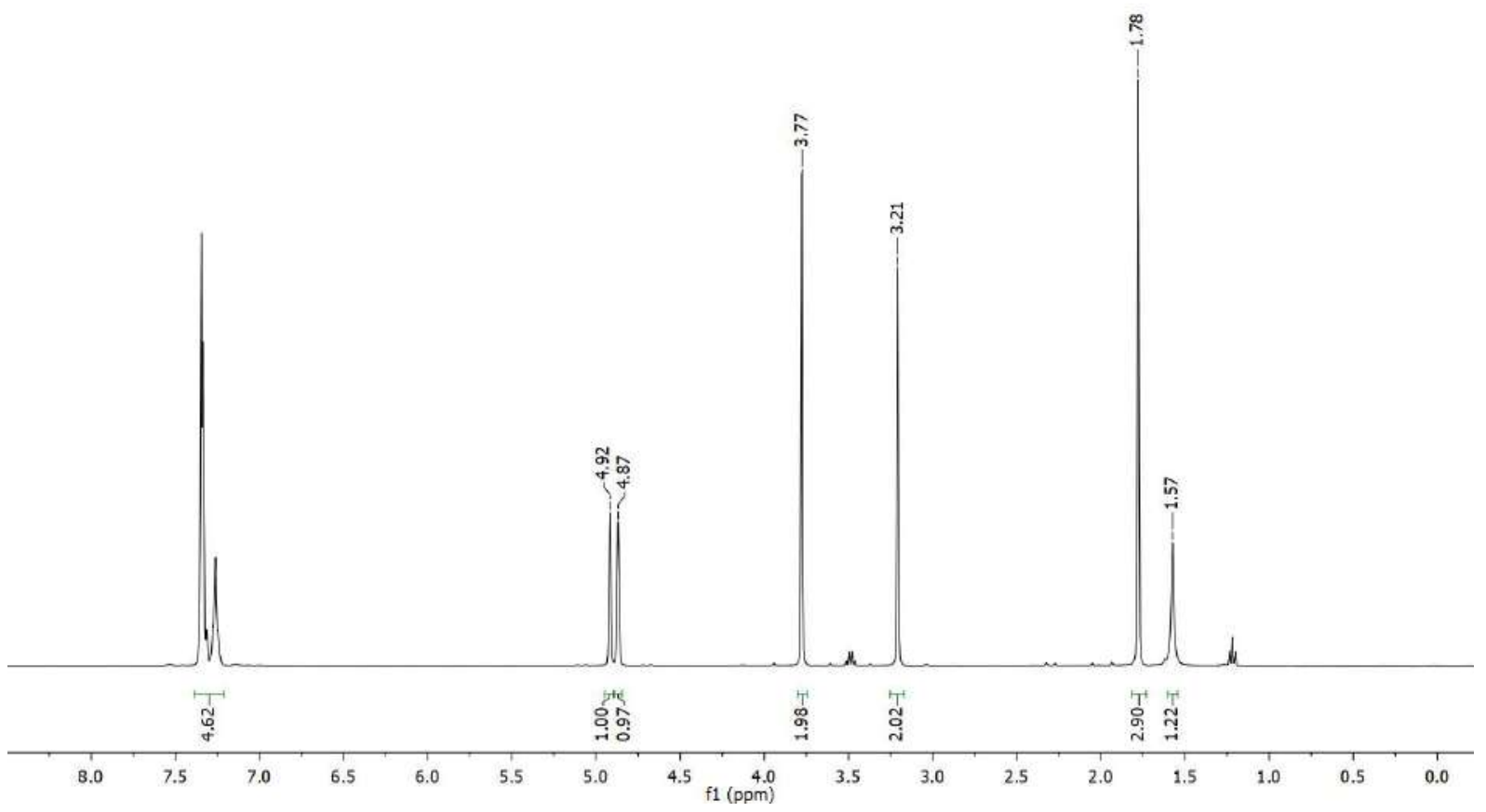

${ }^{13} \mathrm{C}\left\{{ }^{1} \mathrm{H}\right\}$ NMR $\left(101 \mathrm{MHz}, \mathrm{CDCl}_{3}\right)$
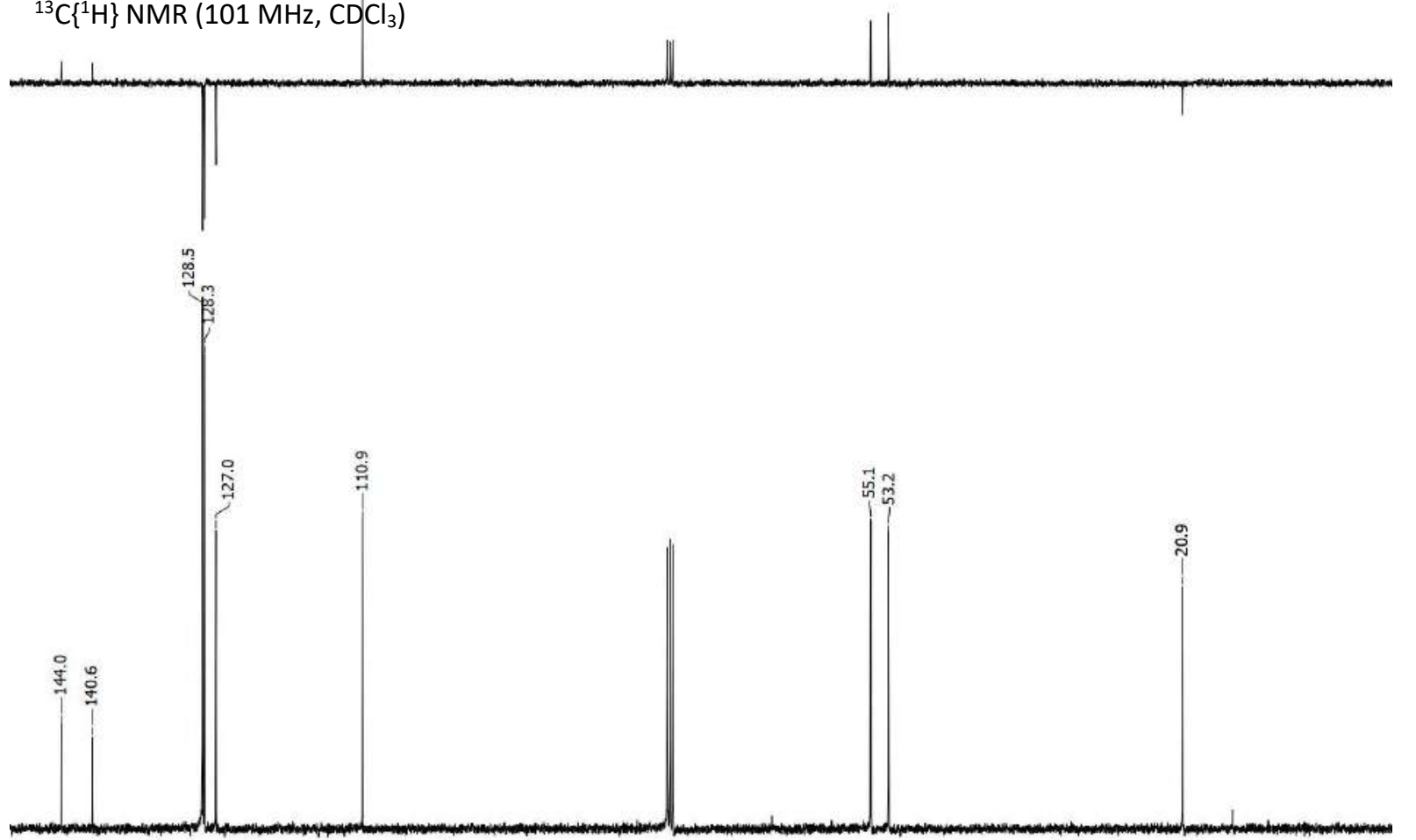

$\begin{array}{lllllllllllllllllllllllllllllllllllllll}145 & 140 & 135 & 130 & 125 & 120 & 115 & 110 & 105 & 100 & 95 & 90 & 85 & 80 & 75 & 70 & 65 & 60 & 55 & 50 & 45 & 40 & 35 & 30 & 25 & 20 & 15 & 10 & 5 & 0\end{array}$ 


\section{N-Benzyl-2-bromo-2-methyl-N-(2-methylallyl)propanamide (1d)}

${ }^{1} \mathrm{H}$ NMR (600 MHz, Toluene- $\left.d_{8}, 95^{\circ} \mathrm{C}\right)$
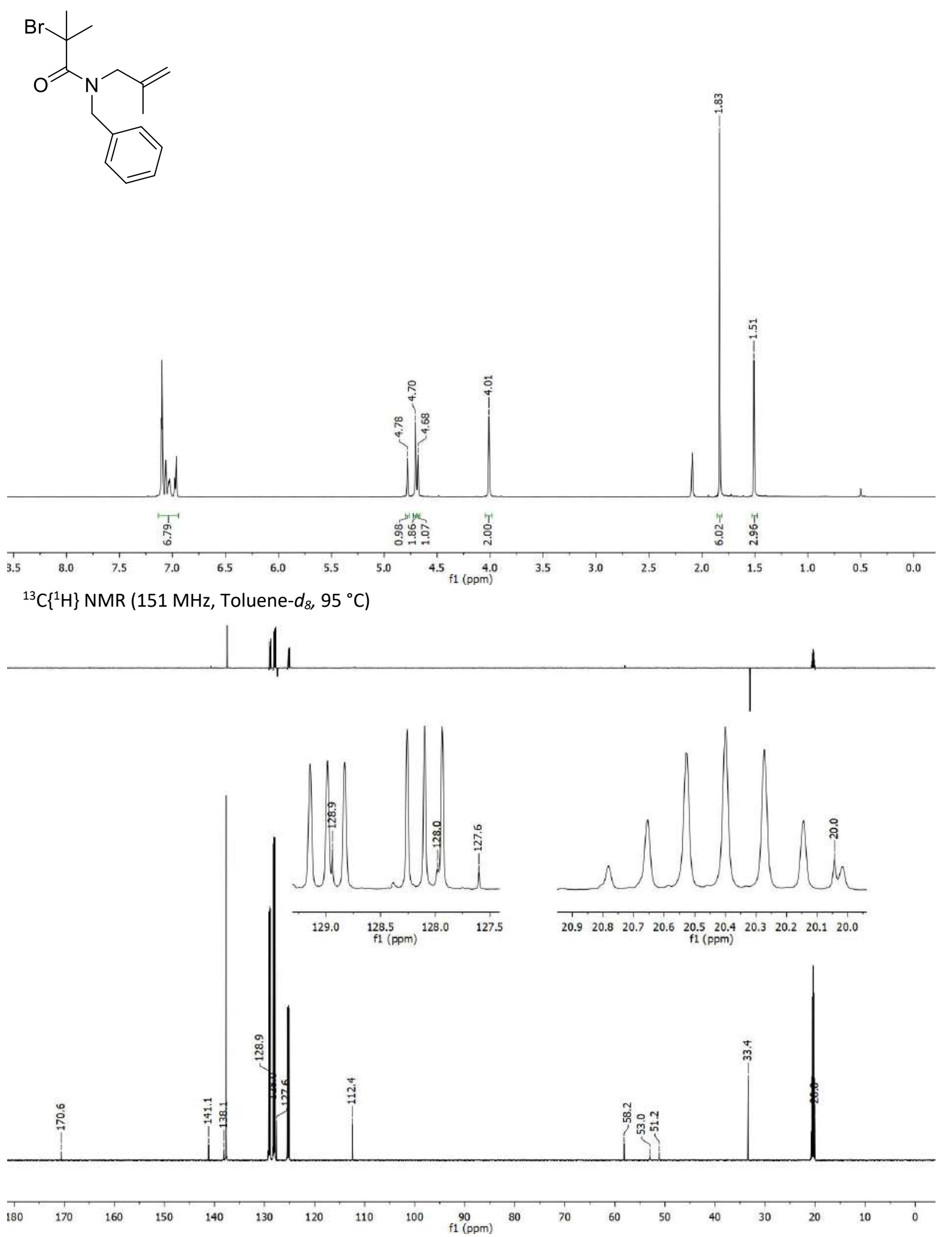
N-benzylhexa-2,4-dien-1-amine product (S1e)

${ }^{1} \mathrm{H}$ NMR $\left(600 \mathrm{MHz}, \mathrm{CDCl}_{3}\right)$

I

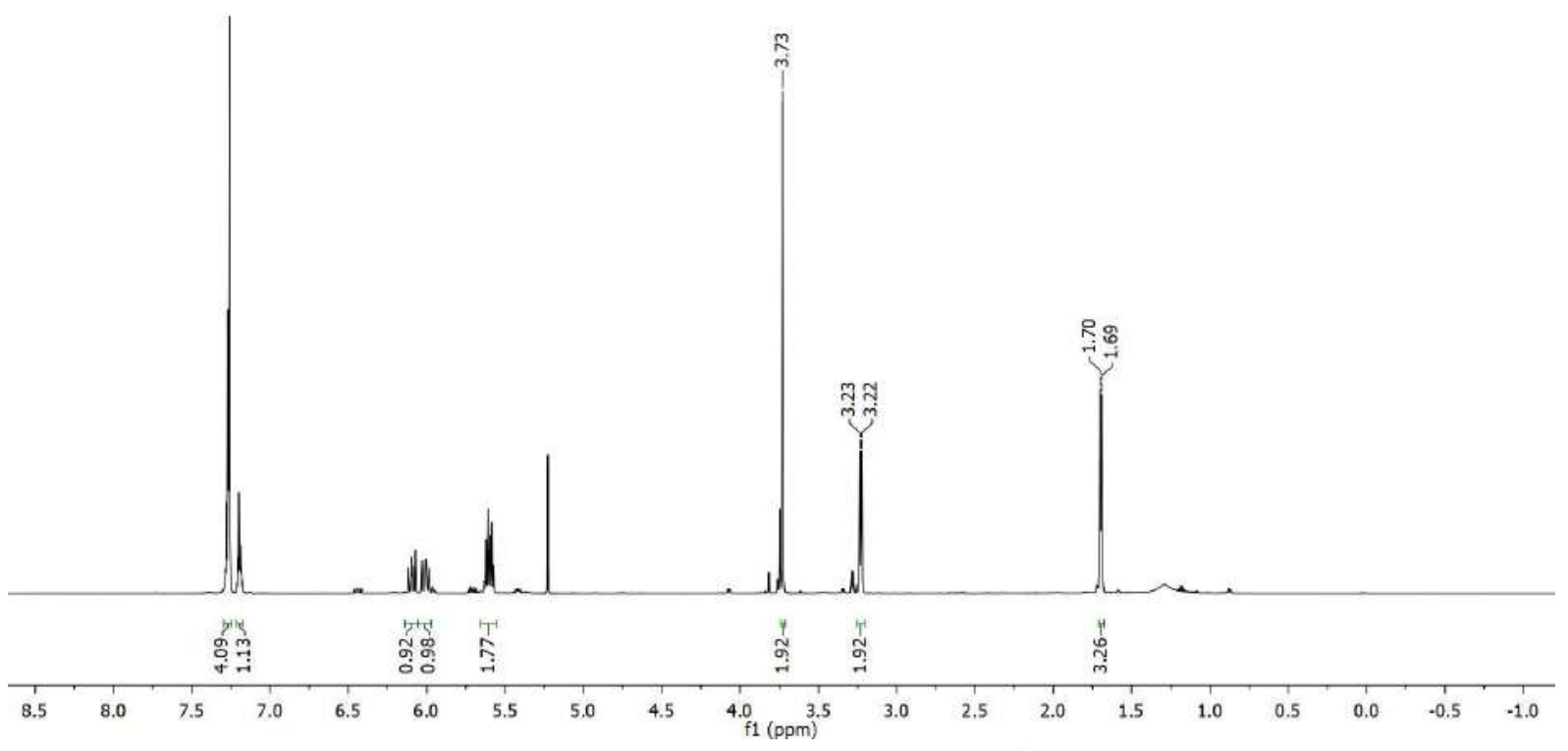

${ }^{13} \mathrm{C}\left\{{ }^{1} \mathrm{H}\right\} \mathrm{NMR}\left(151 \mathrm{MHz}, \mathrm{CDCl}_{3}\right)$
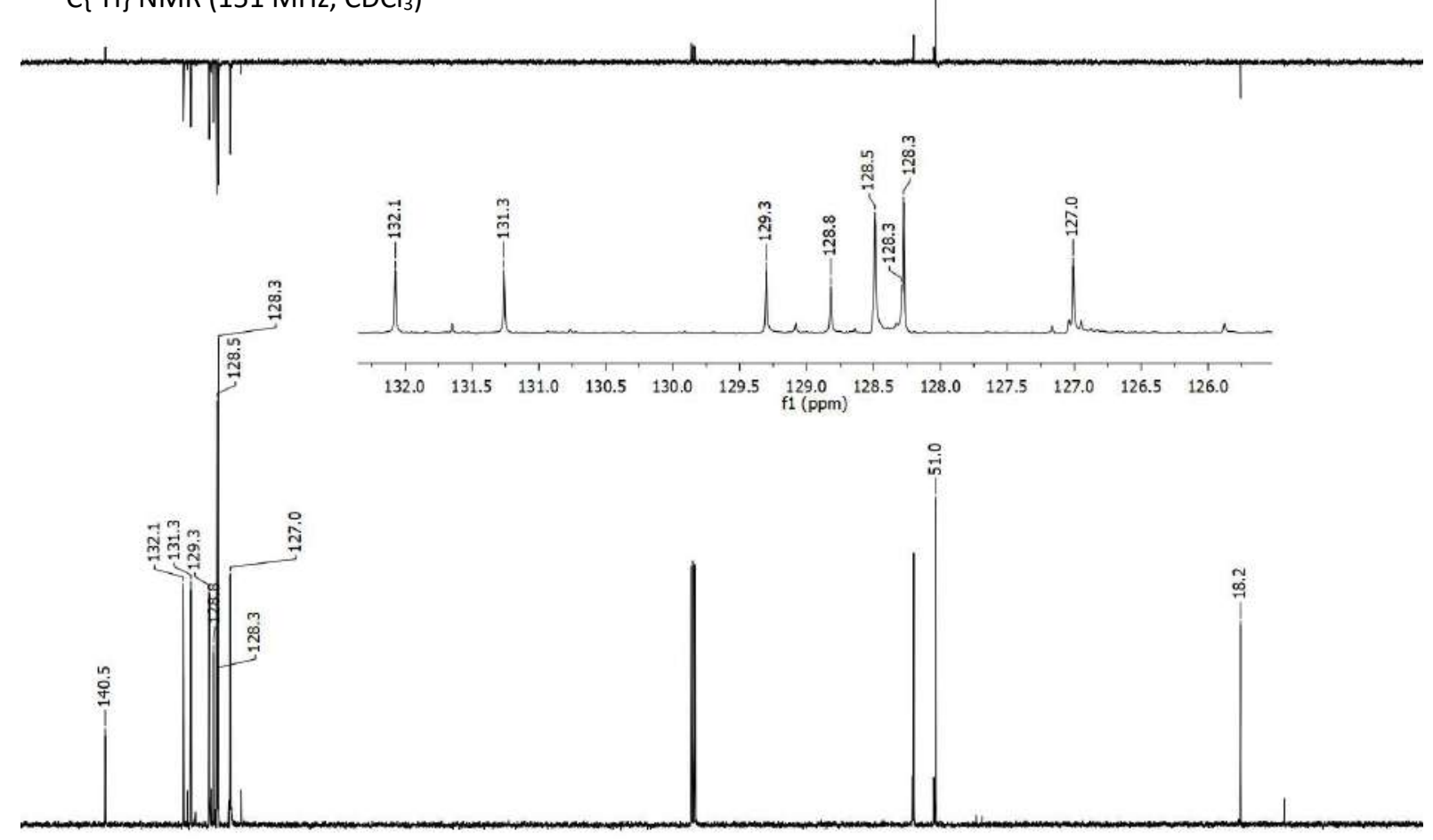

$\begin{array}{lllllllllllllllllllllllllllllllllllllllllllll}145 & 140 & 135 & 130 & 125 & 120 & 115 & 110 & 105 & 100 & 95 & 90 & 85 & 80 & 75 & 70 & 65 & 60 & 55 & 50 & 45 & 40 & 35 & 30 & 25 & 20 & 15 & 10 & 5 & 0\end{array}$ 
N-Benzyl-2-bromo-N-(hexa-2,4-dien-1-yl)-2-methylpropanamide (1e)

${ }^{1} \mathrm{H}$ NMR $\left(600 \mathrm{MHz}\right.$, Toluene- $\left.d_{8}, 95^{\circ} \mathrm{C}\right)$
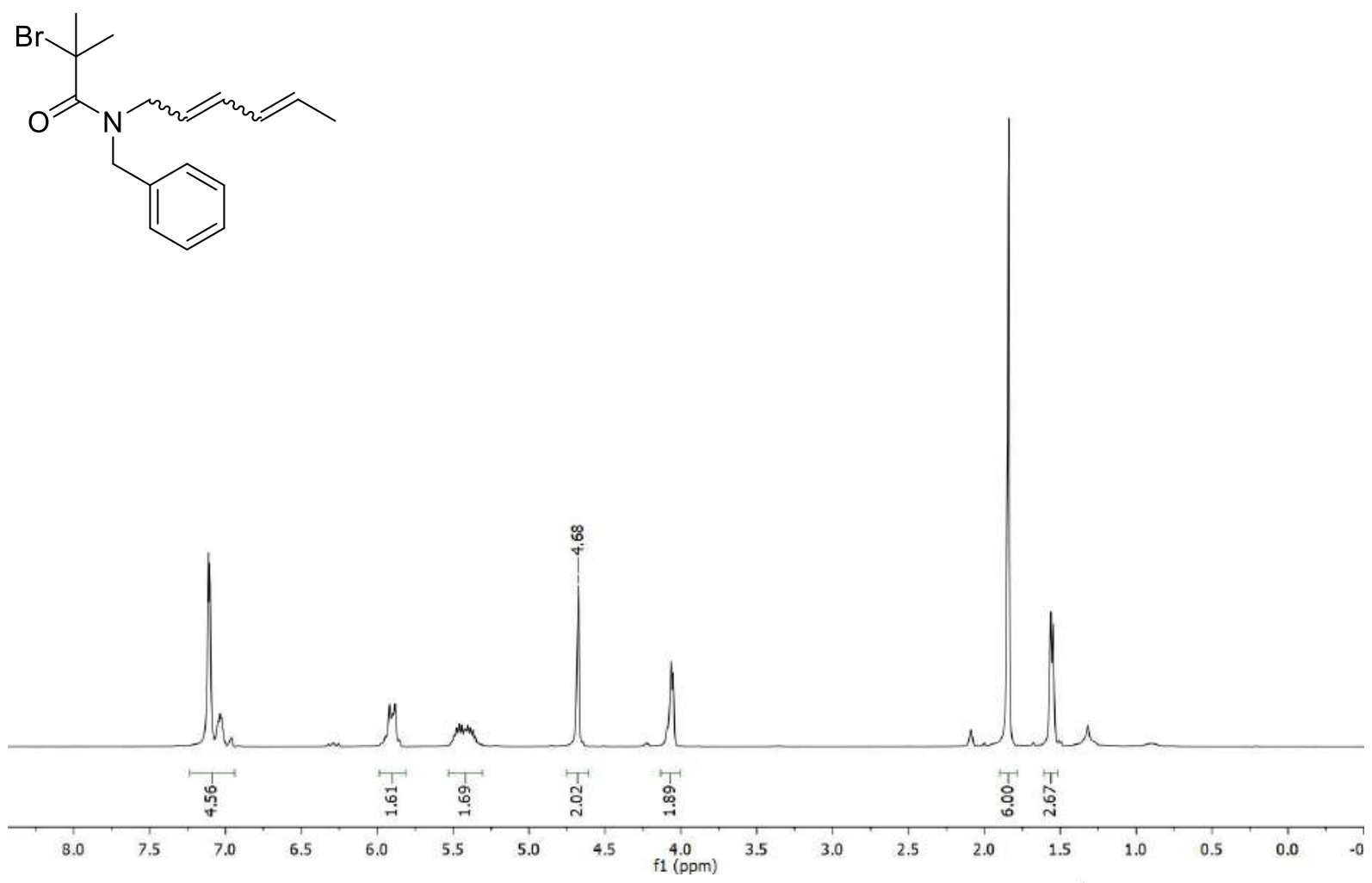

${ }^{13} \mathrm{C}\left\{{ }^{1} \mathrm{H}\right\}$ NMR $\left(151 \mathrm{MHz}\right.$, Toluene- $\left.d_{8}, 95^{\circ} \mathrm{C}\right)$
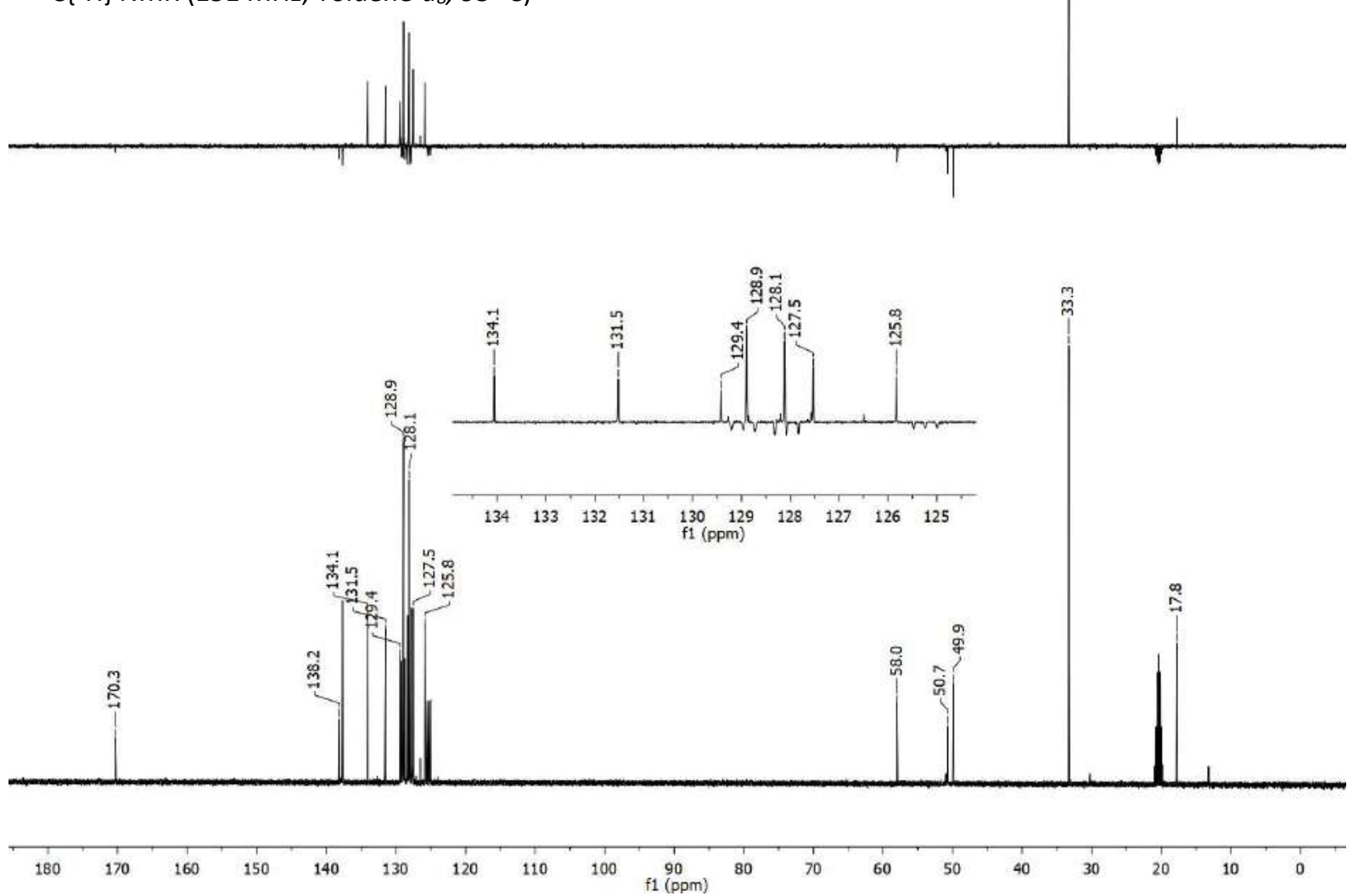
$\boldsymbol{N}$-Benzyl- $\boldsymbol{N}$-prenylamine (S1f)

${ }^{1} \mathrm{H}$ NMR (400 MHz, $\mathrm{CDCl}_{3}$ )<smiles>CC(C)=CCNCc1ccccc1</smiles>
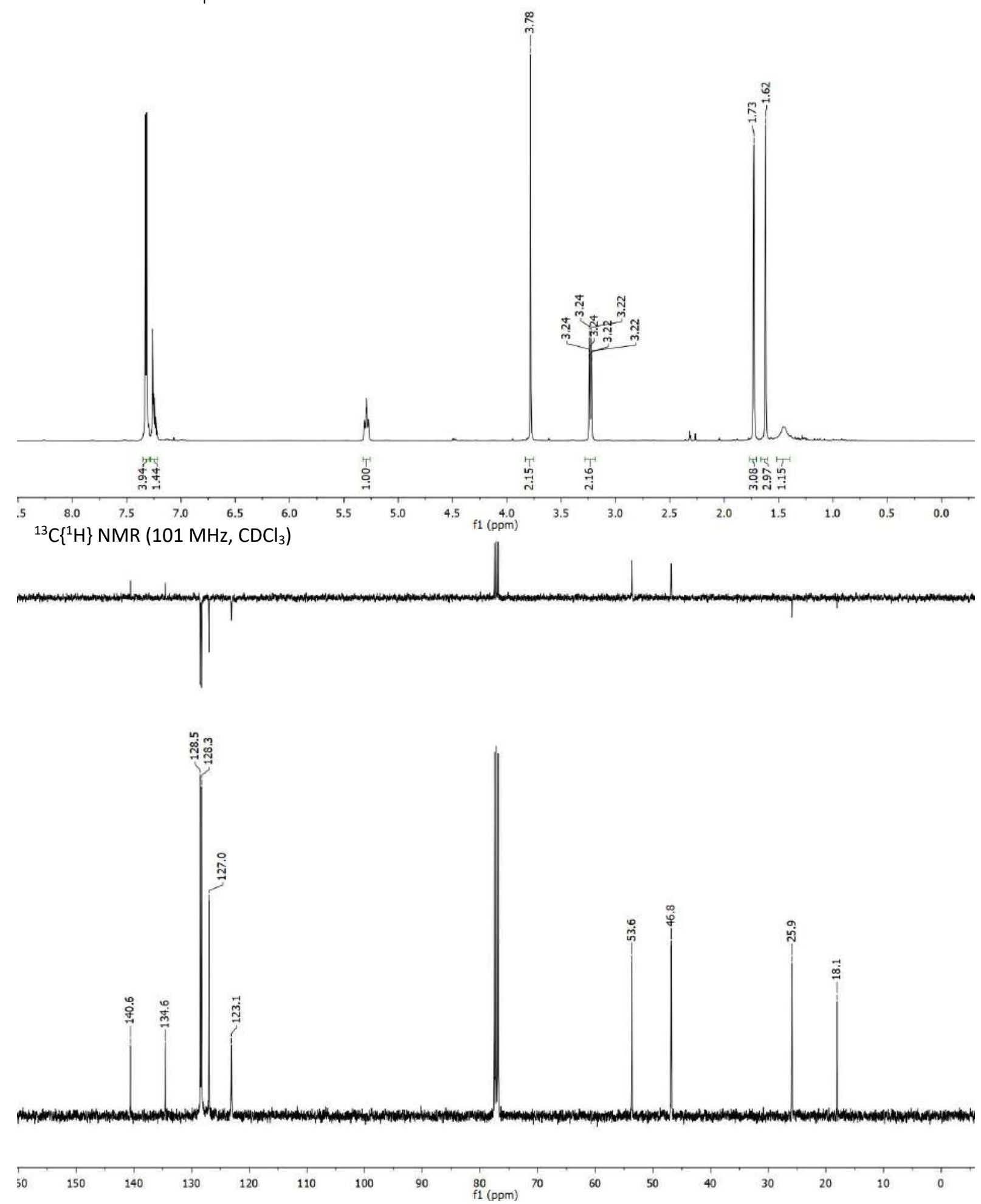
$\mathrm{N}$-Benzyl-2-bromo-2-methyl-N-(3-methylbut-2-en-1-yl)propanamide (1f)

${ }^{1} \mathrm{H}$ NMR (600 MHz, Toluene- $\left.d_{8}, 95^{\circ} \mathrm{C}\right)$<smiles>CC(C)=CCN(Cc1ccccc1)C(=O)C(C)(C)Br</smiles>

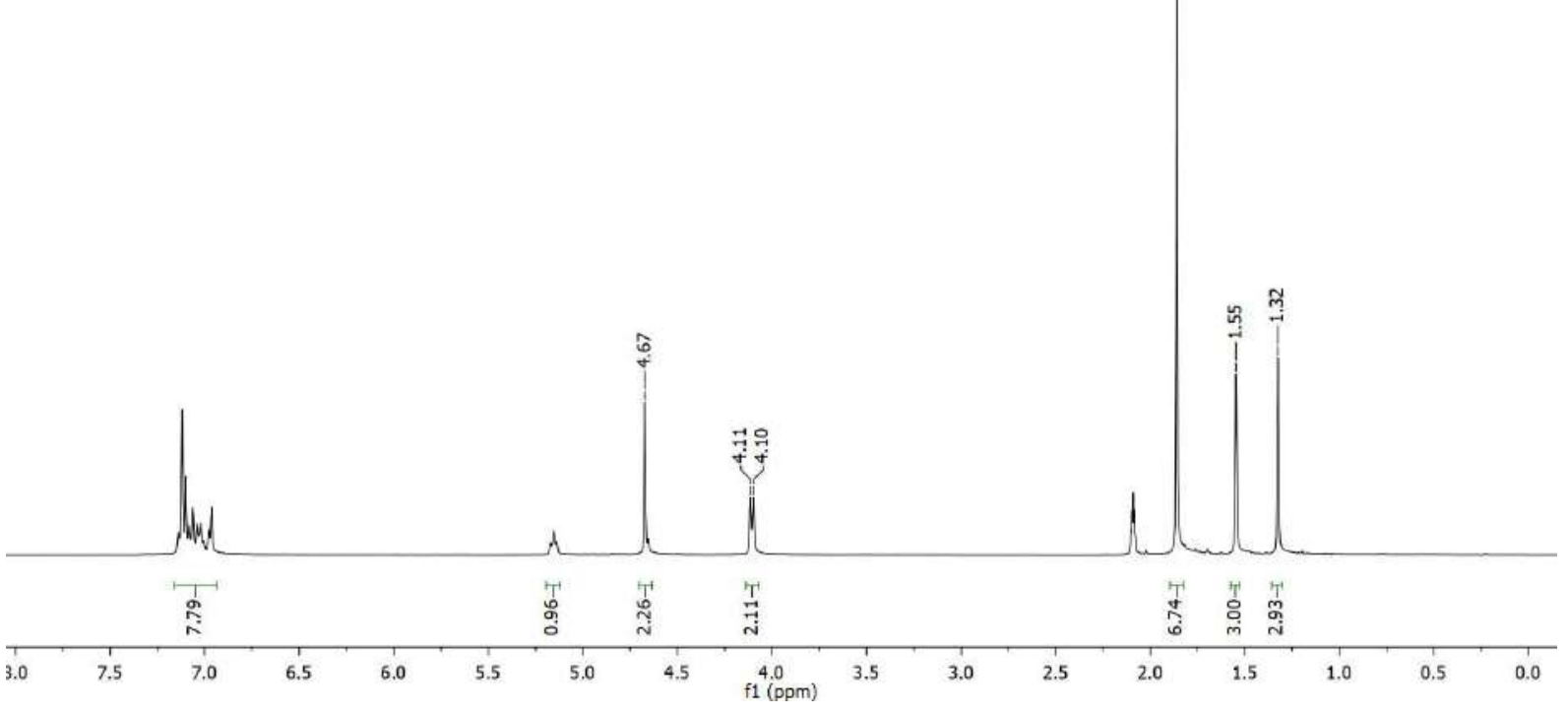

${ }^{13} \mathrm{C}\left\{{ }^{1} \mathrm{H}\right\}$ NMR $\left(151 \mathrm{MHz}\right.$, Toluene- $\left.d_{8}, 95^{\circ} \mathrm{C}\right)$
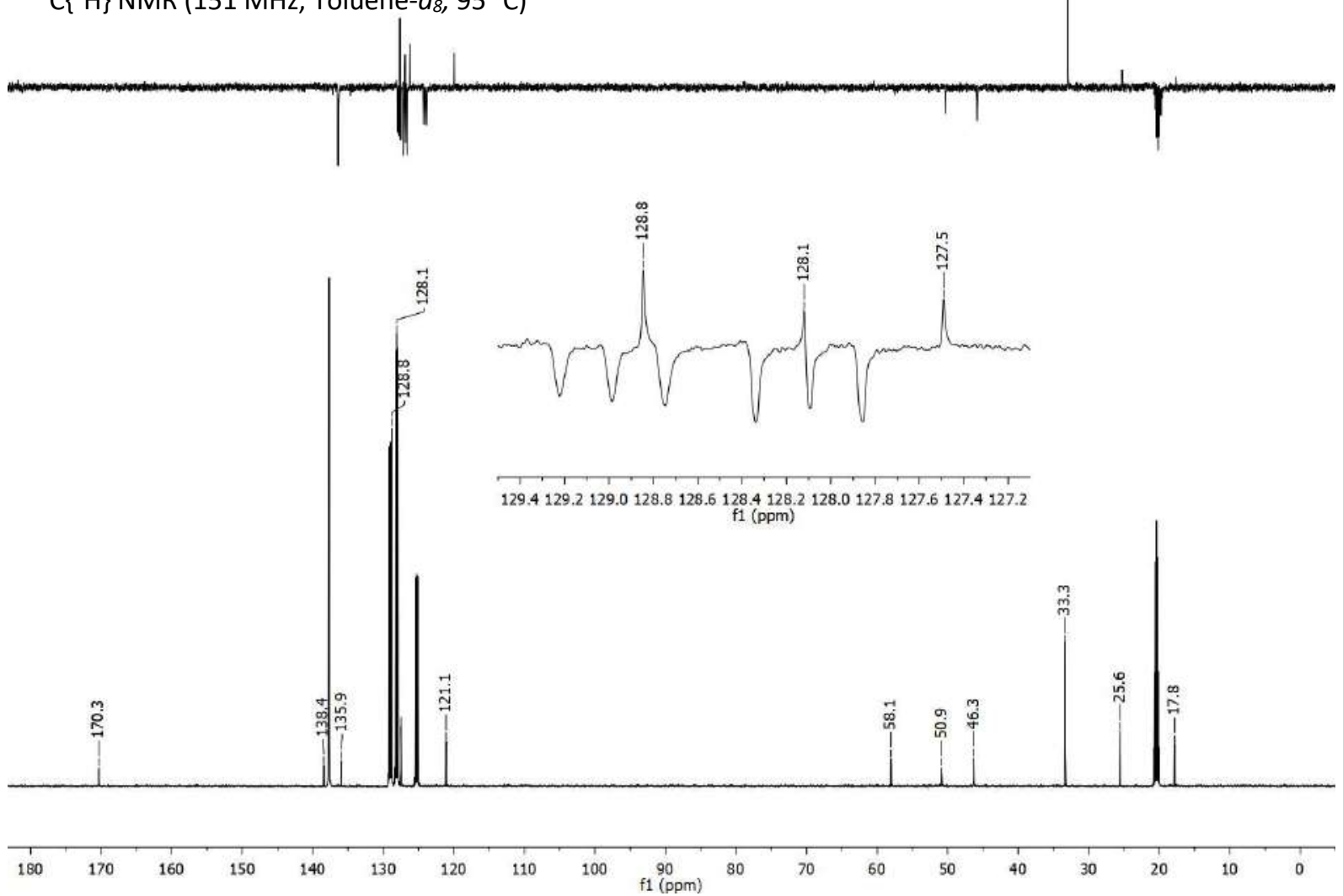
1-Benzyl-4-(bromomethyl)-3,3-dimethylpyrrolidin-2-one (2a)

${ }^{1} \mathrm{H} \mathrm{NMR}\left(600 \mathrm{MHz}, \mathrm{CDCl}_{3}\right)$
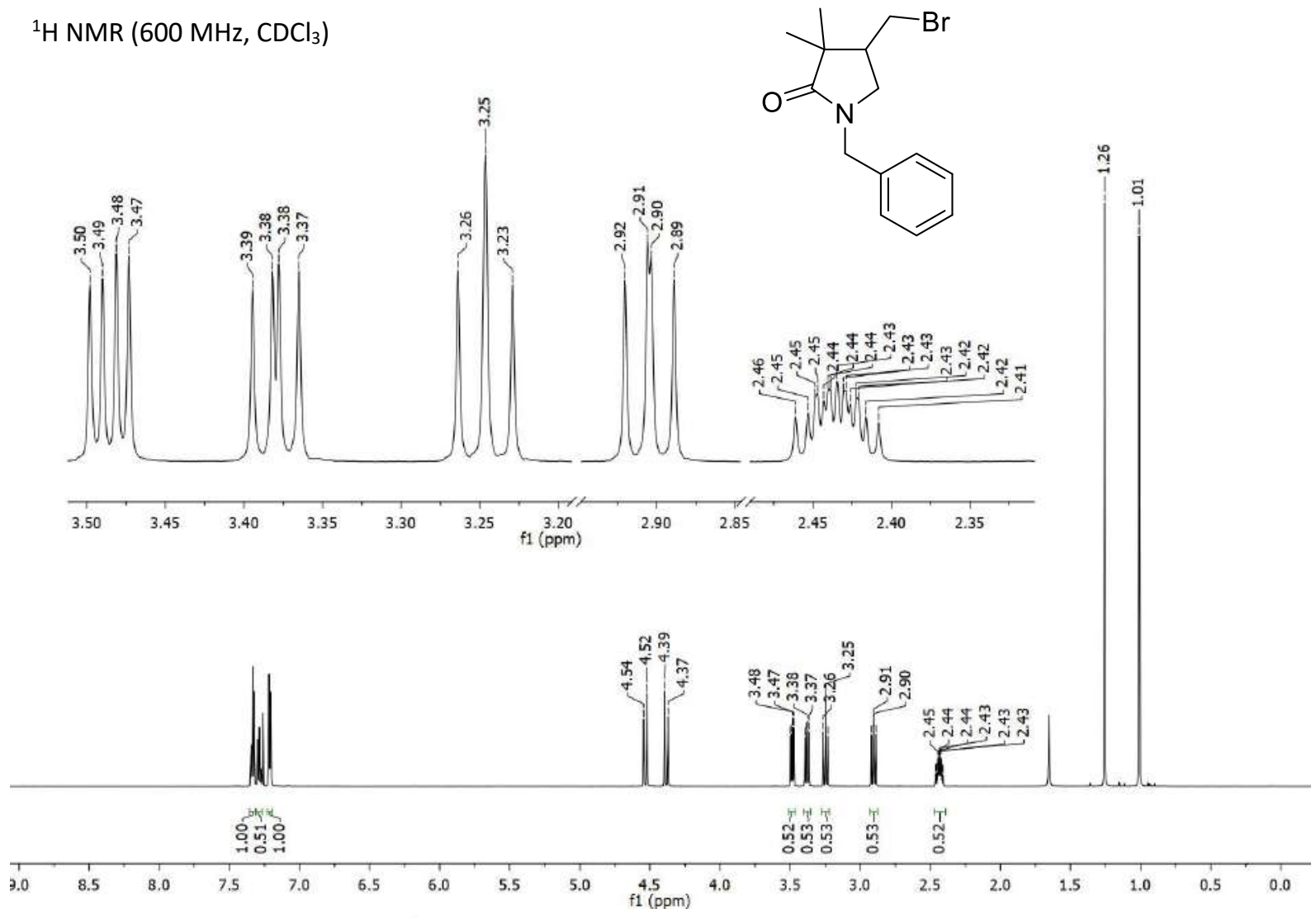

${ }^{13} \mathrm{C}\left\{{ }^{1} \mathrm{H}\right\} \mathrm{NMR}\left(151 \mathrm{MHz}, \mathrm{CDCl}_{3}\right)$
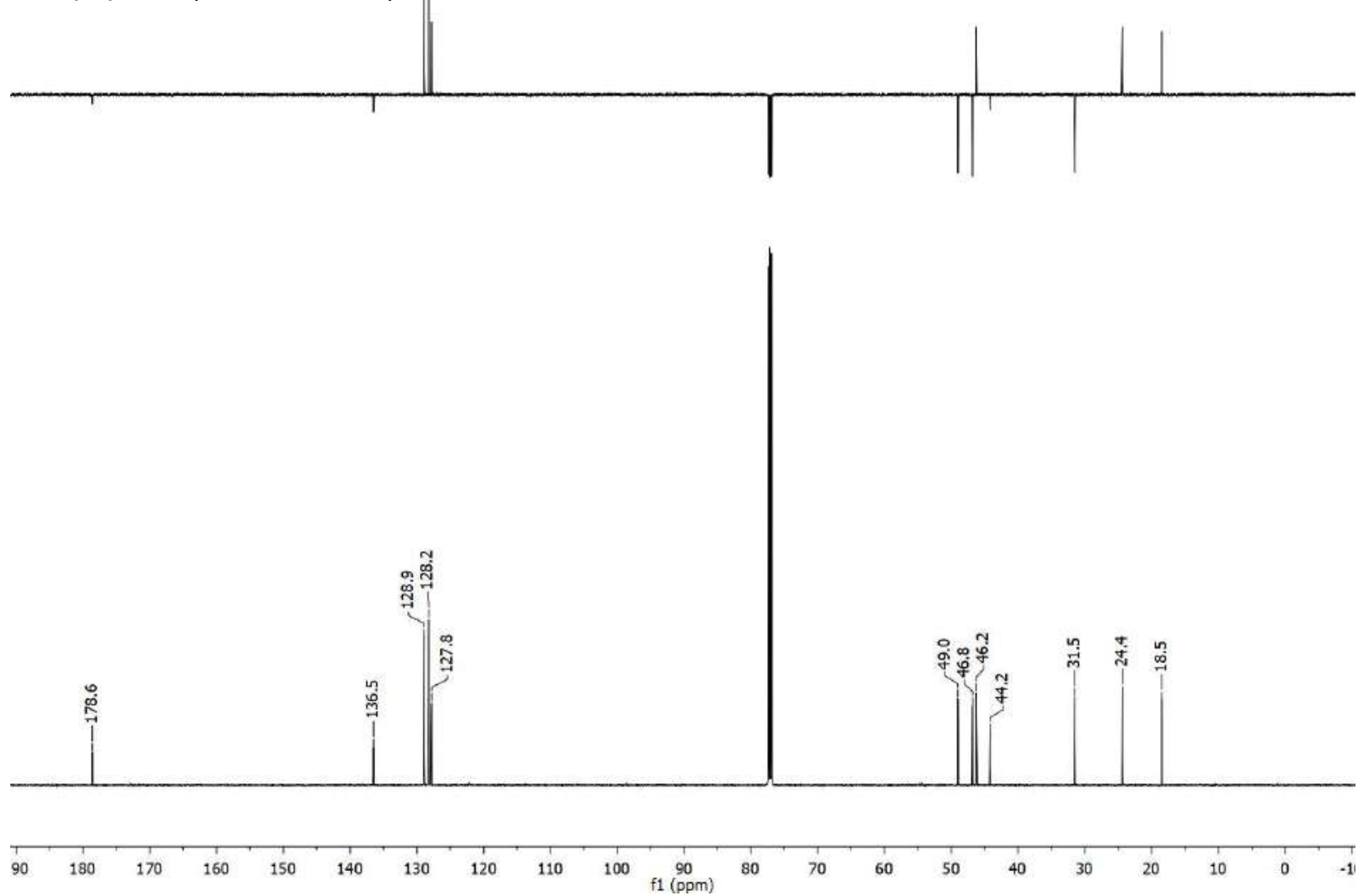
4-(Bromomethyl)-1,3,3-trimethylpyrrolidin-2-one (2b)

${ }^{1} \mathrm{H}$ NMR $\left(600 \mathrm{MHz}, \mathrm{CDCl}_{3}\right)$<smiles>CN1CC(CBr)C(C)(C)C1=O</smiles>

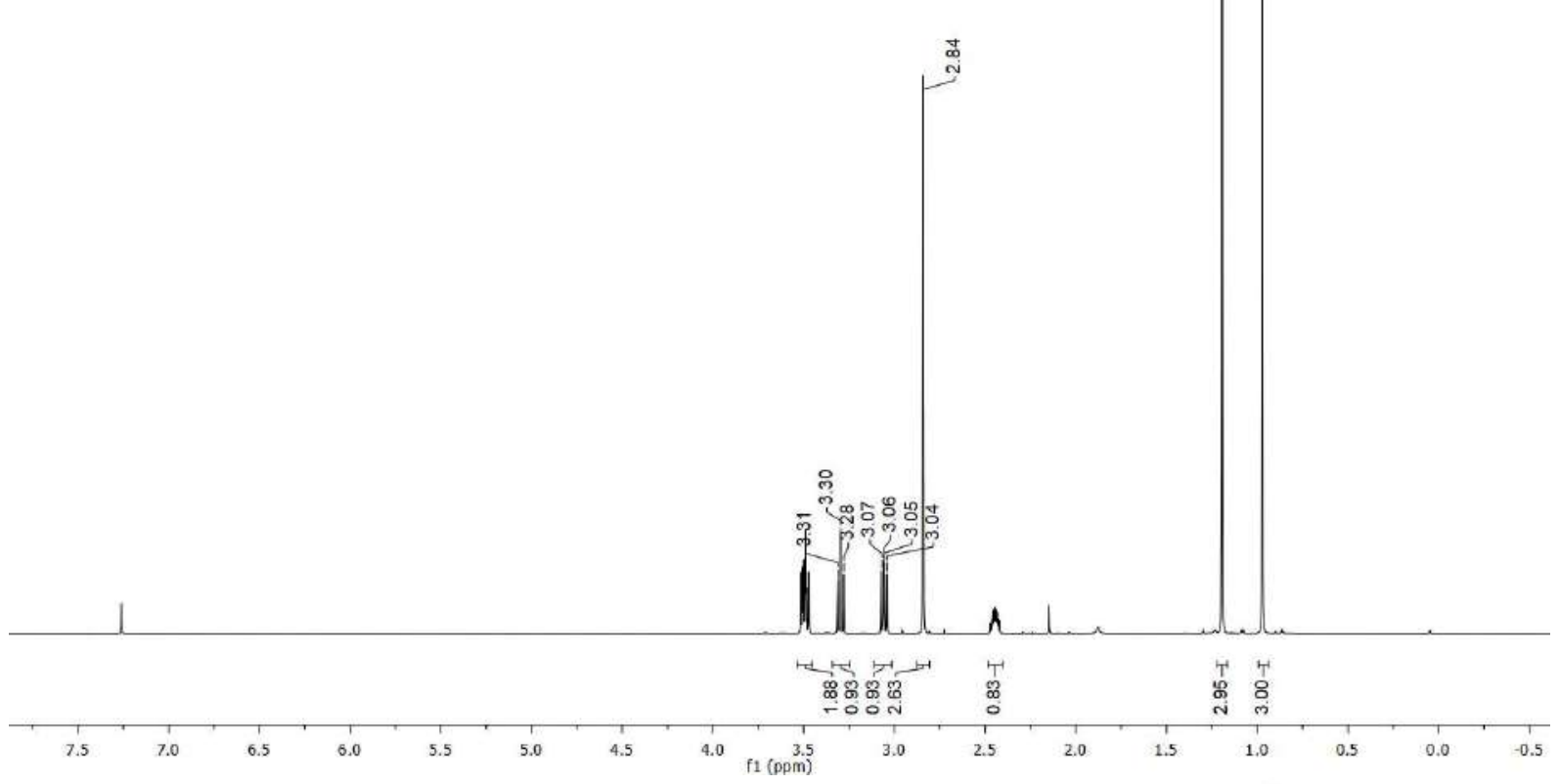

${ }^{13} \mathrm{C}\left\{{ }^{1} \mathrm{H}\right\}$ NMR (151 MHz, $\left.\mathrm{CDCl}_{3}\right)$
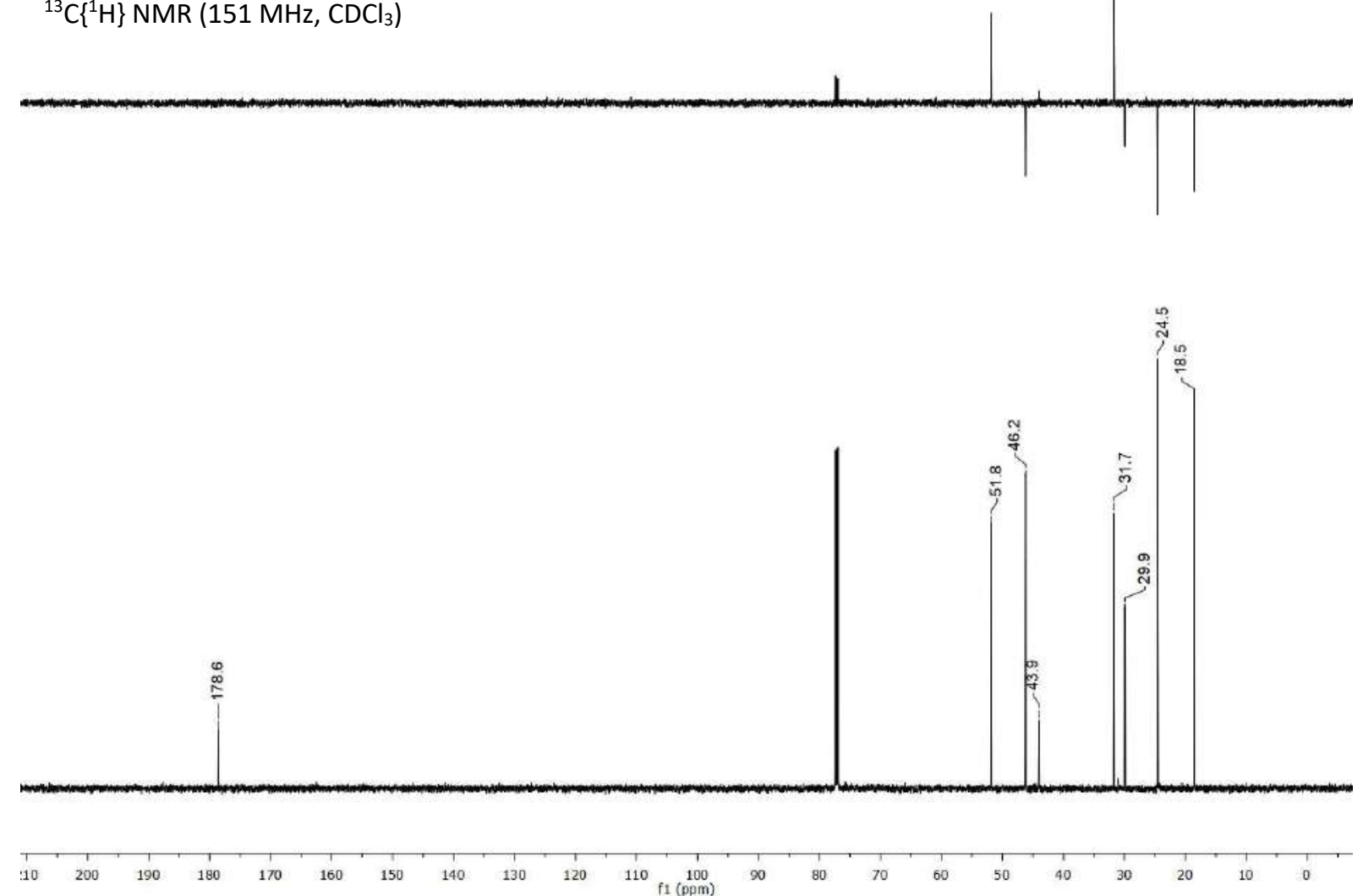
4-(Bromomethyl)-3,3-dimethyl-1-tosylpyrrolidin-2-one (2c)

${ }^{1} \mathrm{H}$ NMR (600 MHz, $\mathrm{CDCl}_{3}$ )<smiles>Cc1ccc(S(=O)(=O)N2CC(CBr)C(C)(C)C2=O)cc1</smiles>

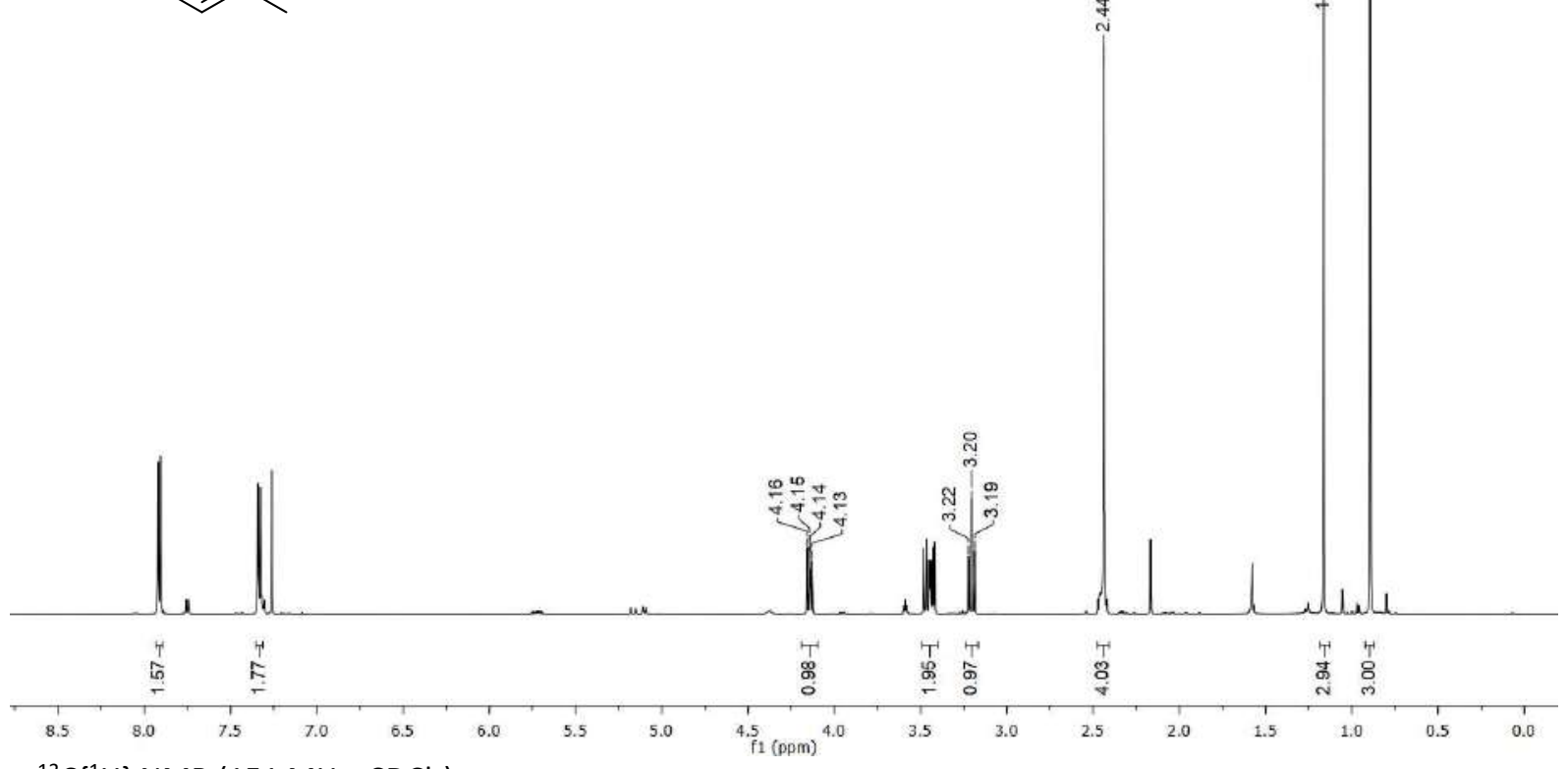

${ }^{13} \mathrm{C}\left\{{ }^{1} \mathrm{H}\right\}$ NMR (151 MHz, $\mathrm{CDCl}_{3}$ )
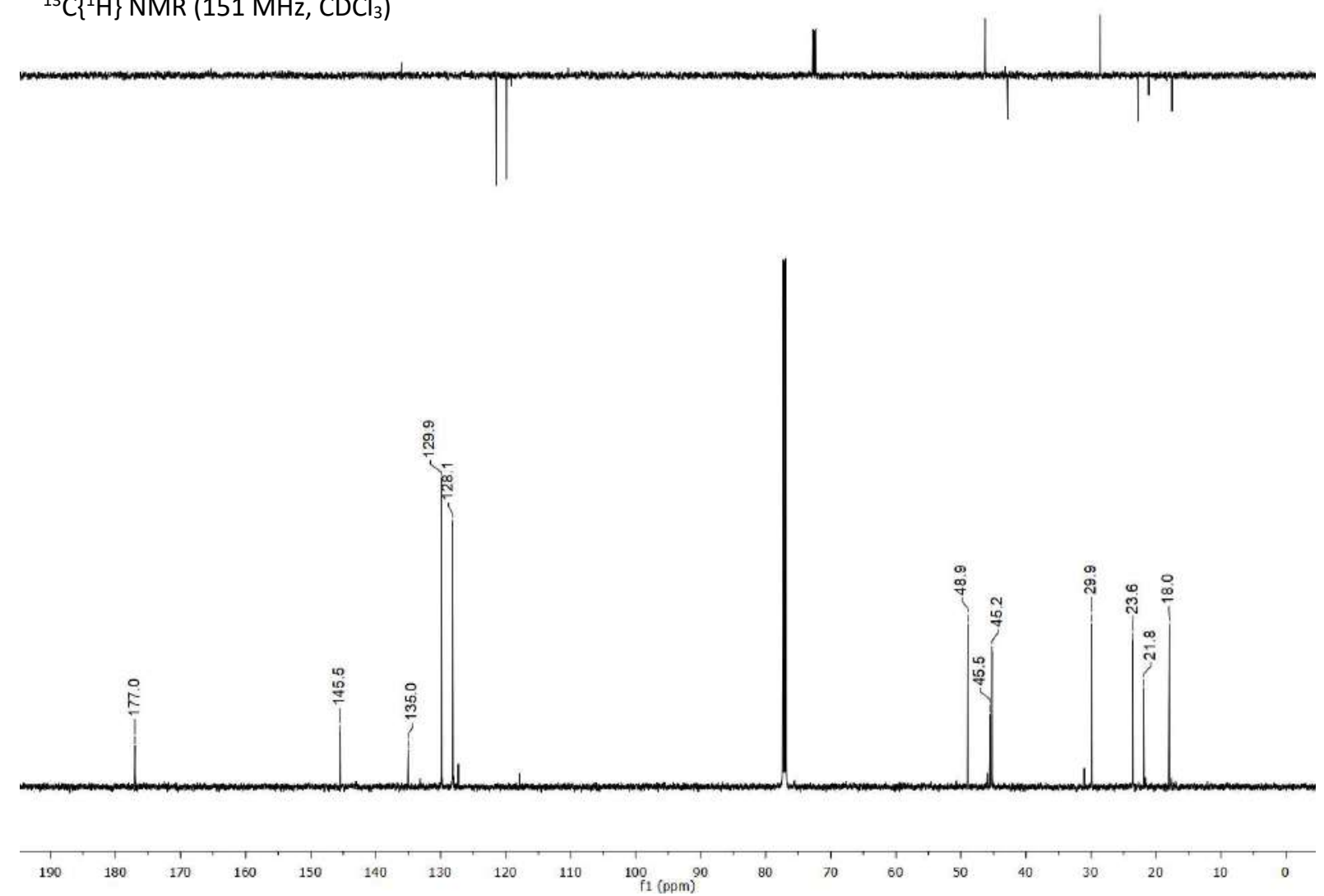
1-Benzyl-4-(bromomethyl)-3,3,4-trimethylpyrrolidin-2-one (2d)

${ }^{1} \mathrm{H} \mathrm{NMR}\left(600 \mathrm{MHz}, \mathrm{CDCl}_{3}\right)$<smiles>CC1(C)CN(Cc2ccccc2)C(=O)C1(C)CBr</smiles>

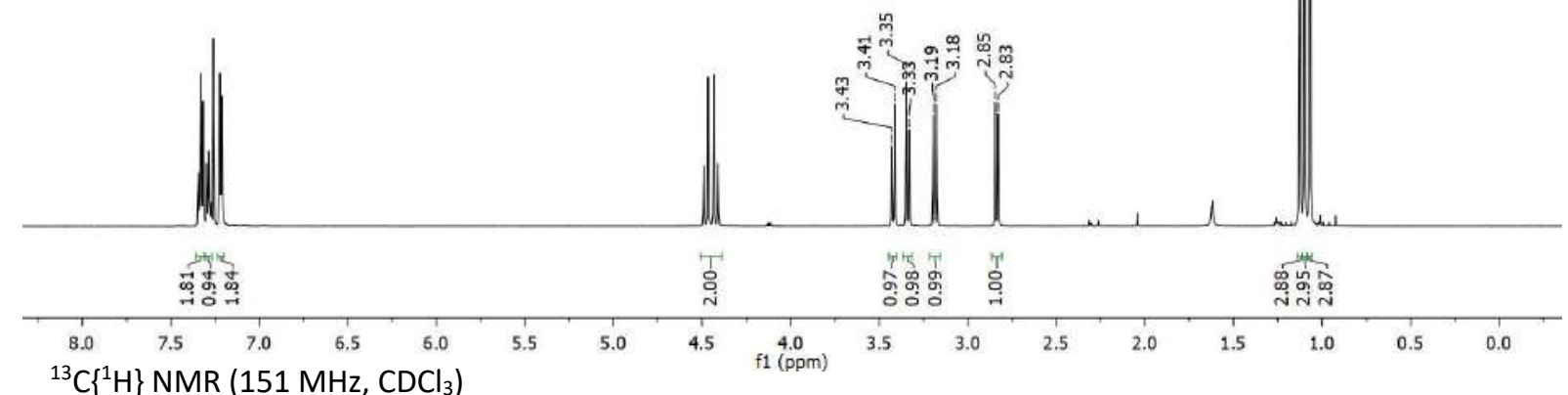

${ }^{13} \mathrm{C}\left\{{ }^{1} \mathrm{H}\right\}$ NMR (151 MHz, $\mathrm{CDCl}_{3}$ )
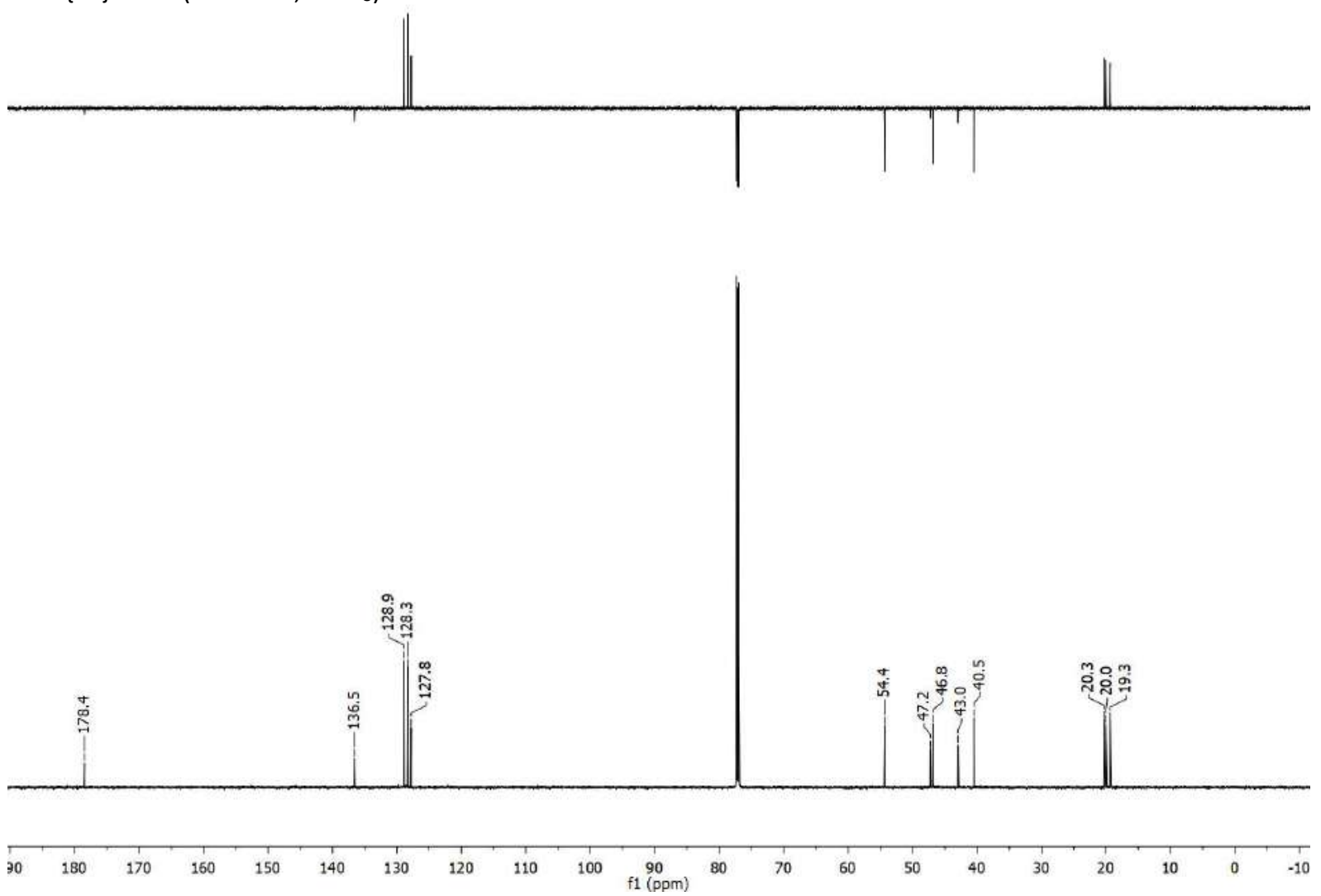


\section{(E)-1-benzyl-4-(3-bromobut-1-en-1-yl)-3,3-dimethylpyrrolidin-2-one (2e)}

${ }^{1} \mathrm{H} \mathrm{NMR}\left(600 \mathrm{MHz}, \mathrm{CDCl}_{3}\right)$<smiles>CC(Br)C=CC1CN(Cc2ccccc2)C(=O)C1(C)C</smiles>
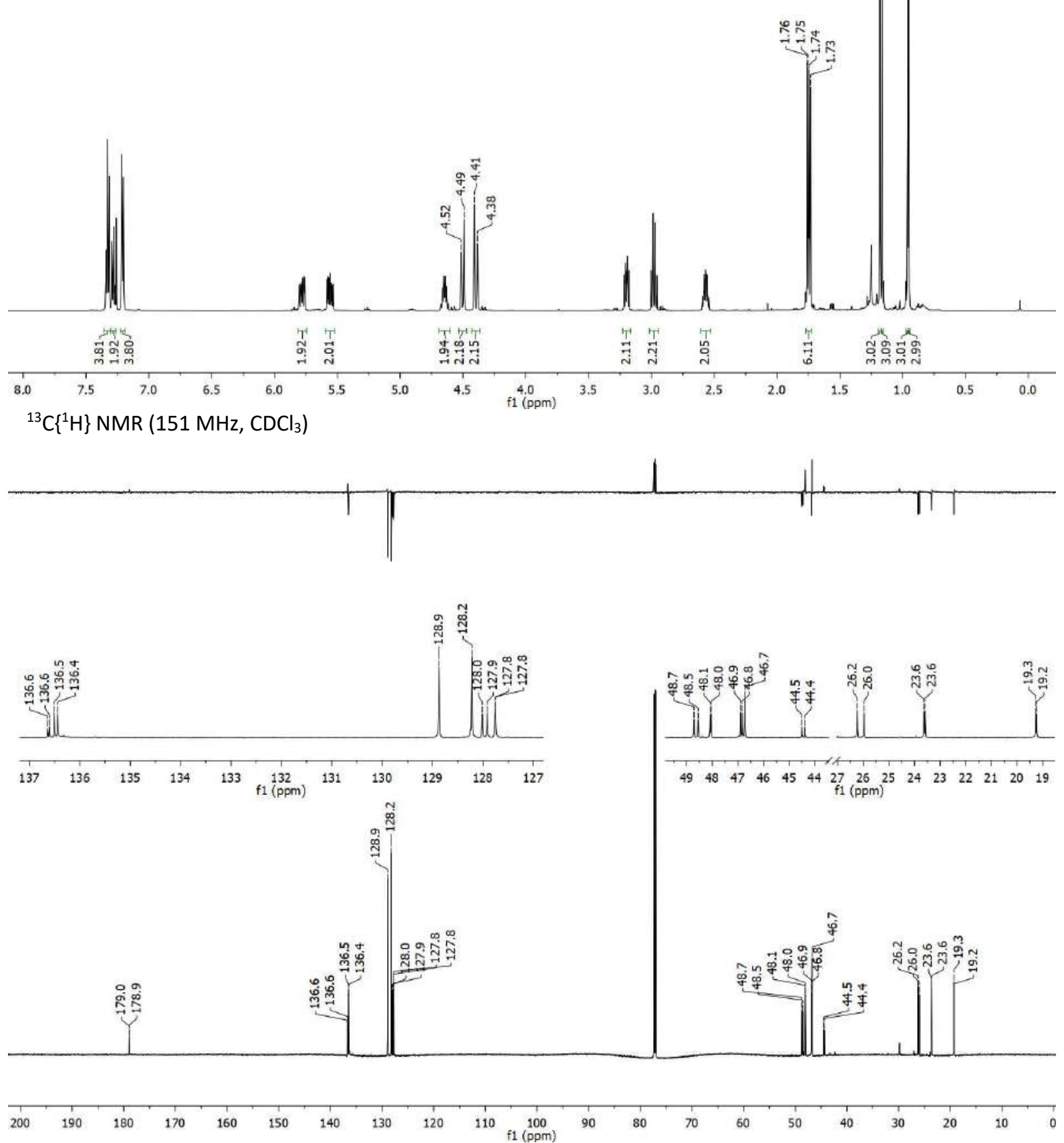
1D Selective Gradient COSY, freq: $\mathbf{5 . 6 9 8} \mathrm{ppm}$

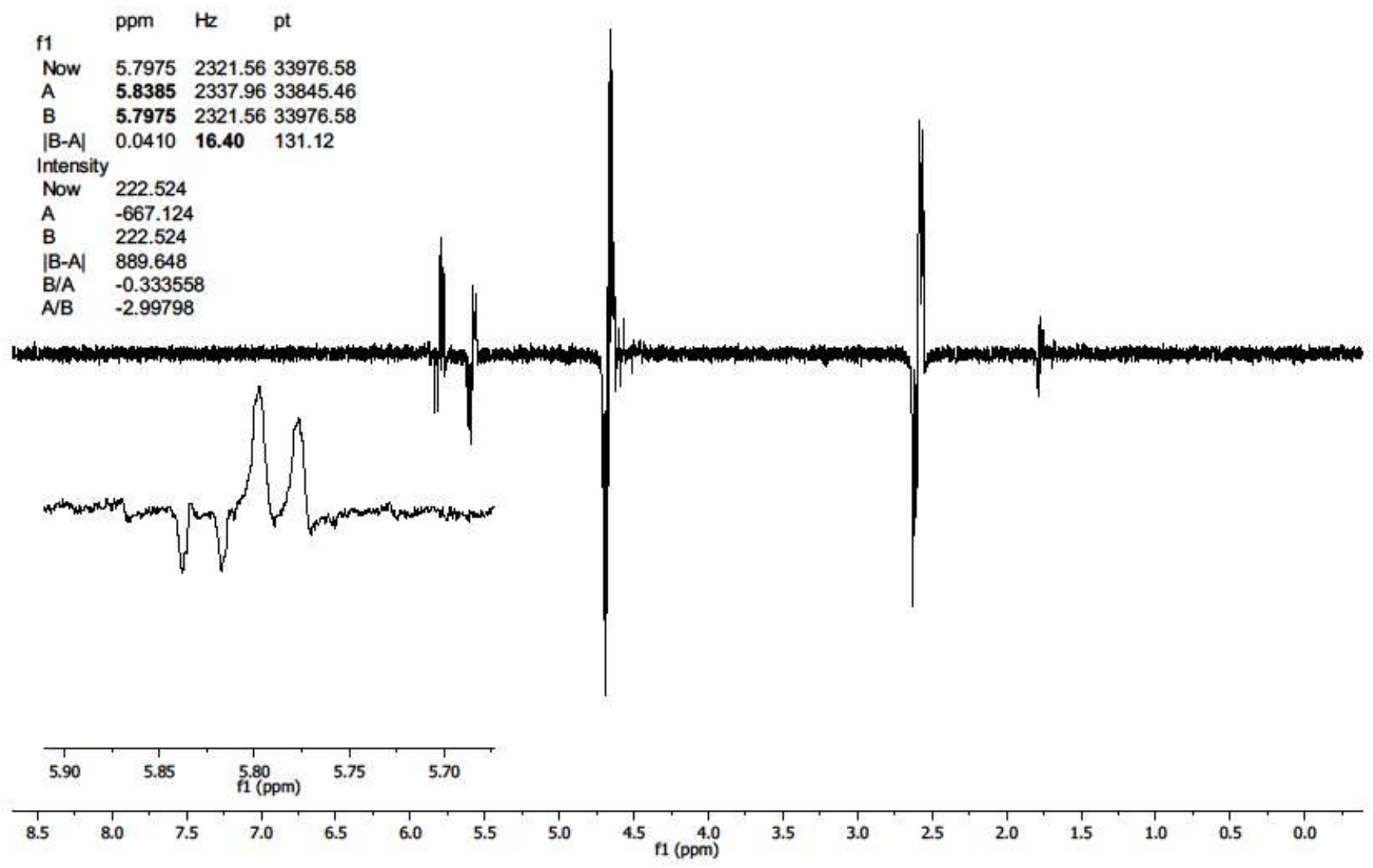


1-Benzyl-3,3-dimethyl-4-(prop-1-en-2-yl)pyrrolidin-2-one (2f) and 1-Benzyl-3,3-dimethyl-4-(propan-2ylidene)pyrrolidin-2-one (2f')

${ }^{1} \mathrm{H}$ NMR $\left(600 \mathrm{MHz}, \mathrm{CDCl}_{3}\right)$

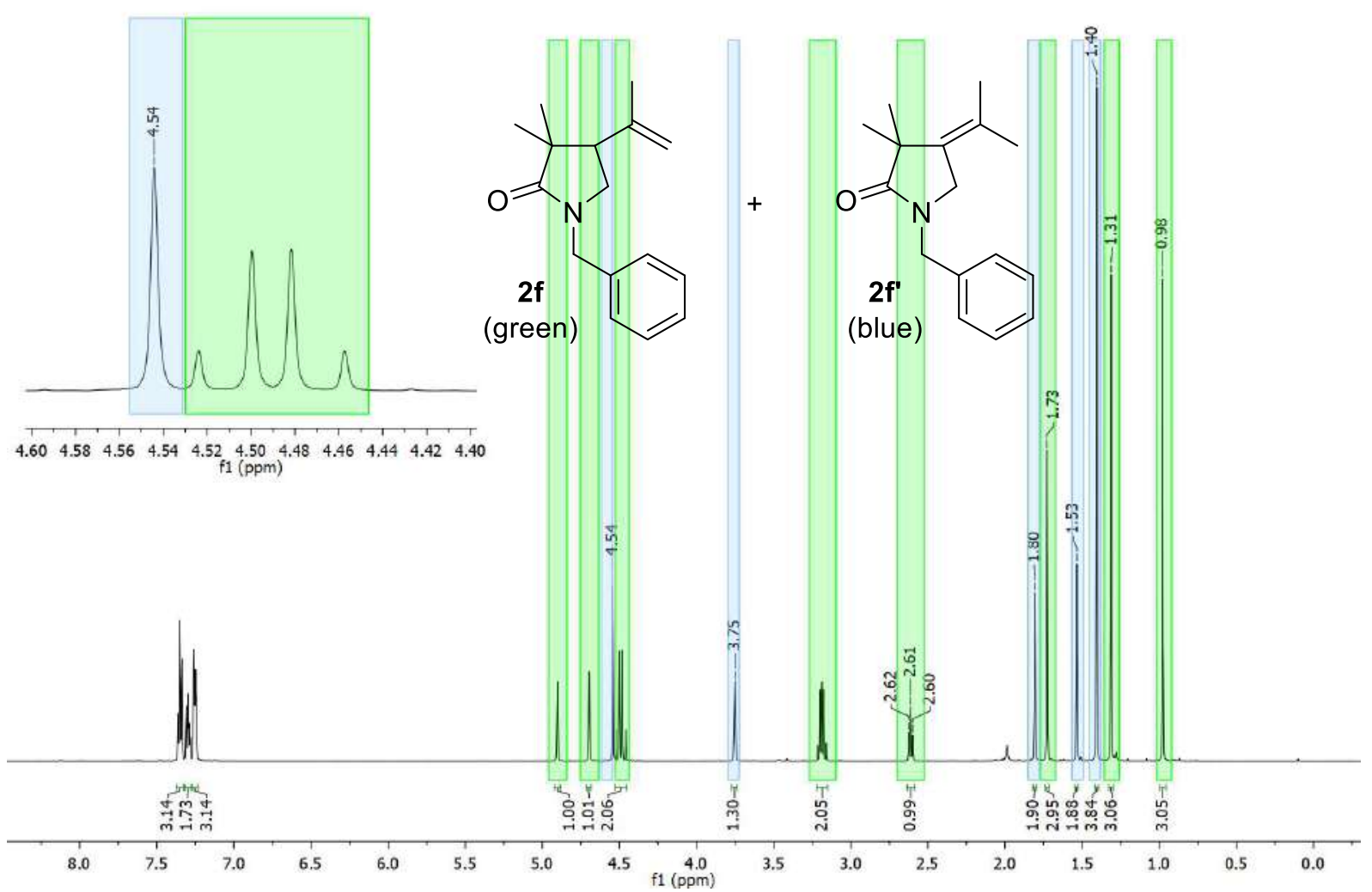

${ }^{13} \mathrm{C}\left\{{ }^{1} \mathrm{H}\right\}$ NMR $\left(151 \mathrm{MHz}, \mathrm{CDCl}_{3}\right)$
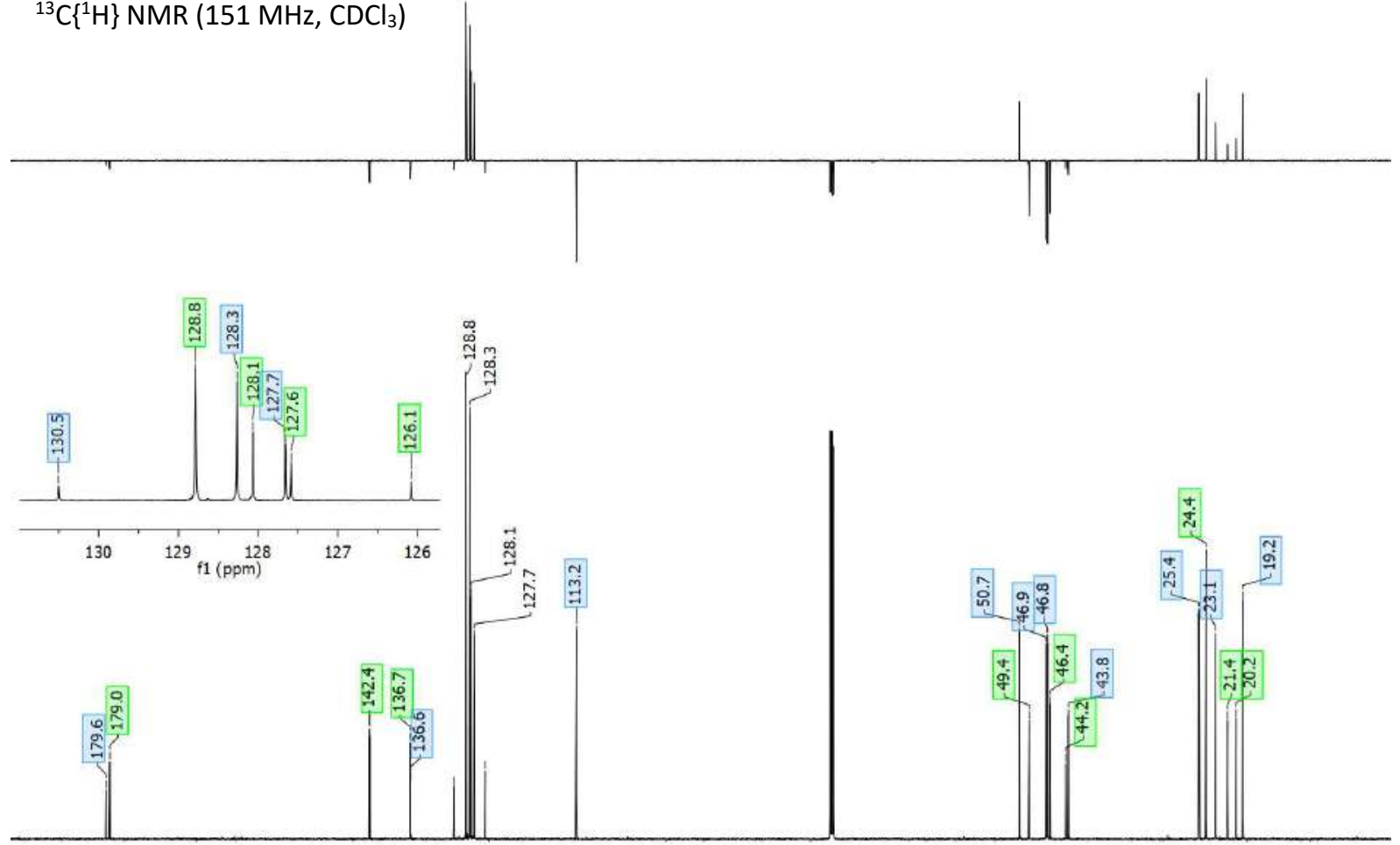

190
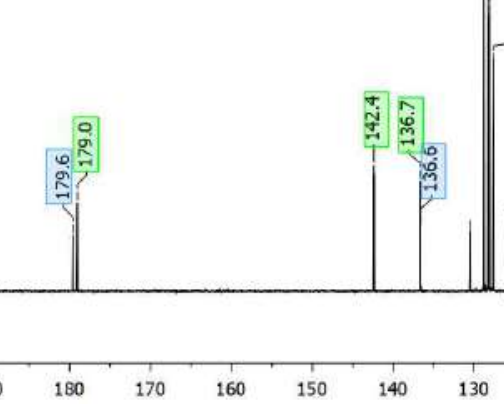


\section{6-Phenylnaphthalen-2-ol (3e)}

${ }^{1} \mathrm{H}$ NMR $\left(400 \mathrm{MHz}, \mathrm{DMSO}-d_{6}\right)$<smiles>Oc1ccc2cc(-c3ccccc3)ccc2c1</smiles>

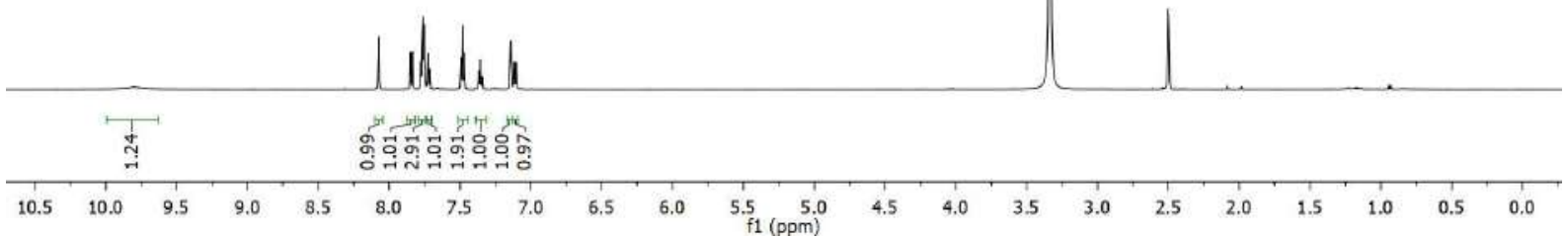

${ }^{13} \mathrm{C}\left\{{ }^{1} \mathrm{H}\right\}$ NMR (101 MHz, DMSO- $d_{6}$ )
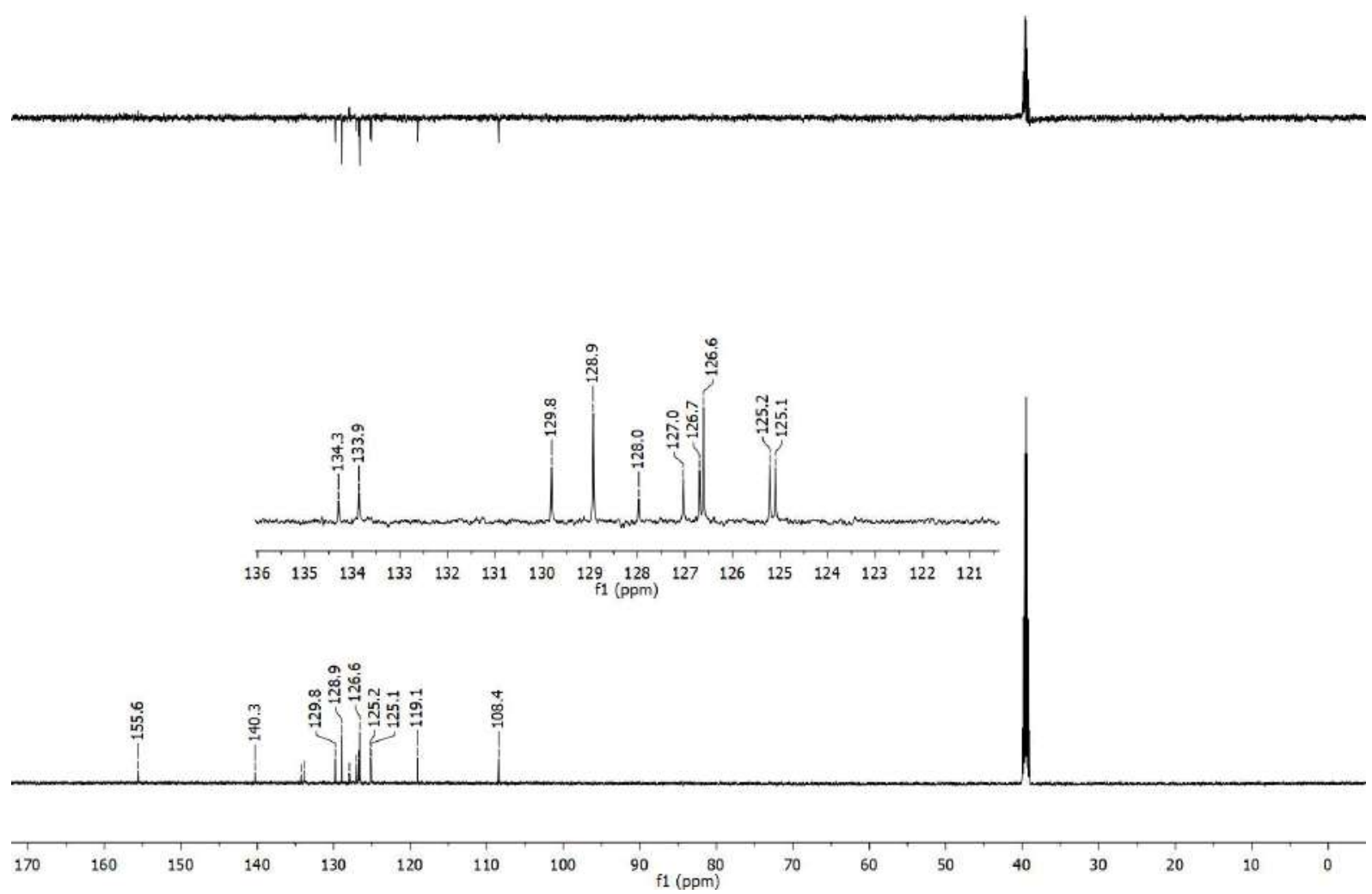


\section{[1,2'-Binaphthalen]-6'-ol (3f)}

${ }^{1} \mathrm{H}$ NMR (400 MHz, DMSO- $d_{6}$ )<smiles>Oc1ccc2cc(-c3cccc4ccccc34)ccc2c1</smiles>
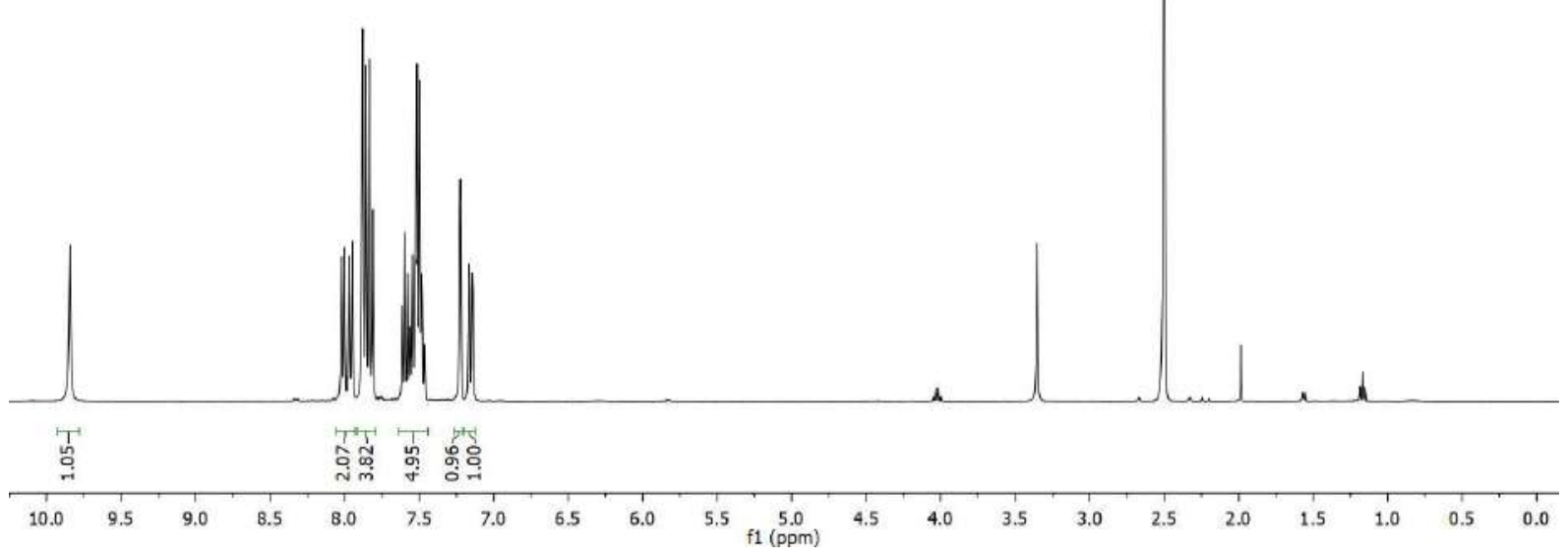

${ }^{13} \mathrm{C}\left\{{ }^{1} \mathrm{H}\right\}$ NMR (101 MHz, DMSO- $d_{6}$ )
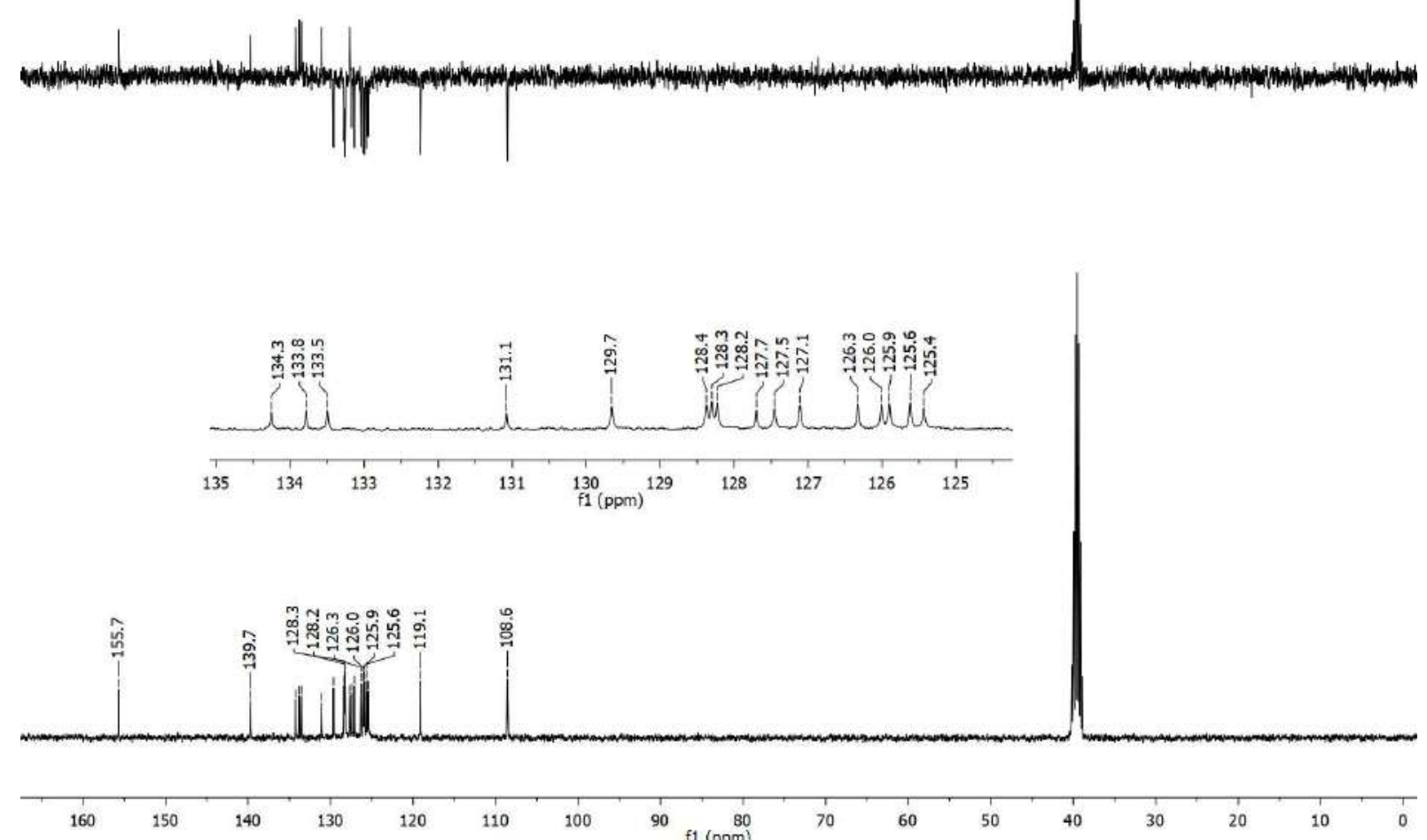

$90 \begin{array}{r}80 \\ \mathrm{f1}(\mathrm{ppm})\end{array}$

60

50

40

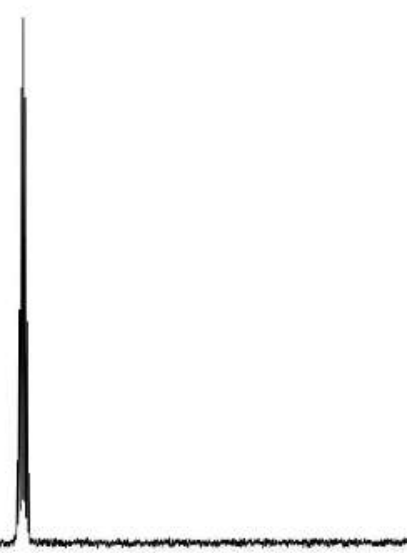




\section{[1,1'-binaphthalene]-2,2'-diol (4a)}

${ }^{1} \mathrm{H}$ NMR $\left(400 \mathrm{MHz}, \mathrm{CDCl}_{3}\right)$<smiles>Oc1ccc2ccccc2c1-c1c(O)ccc2ccccc12</smiles>

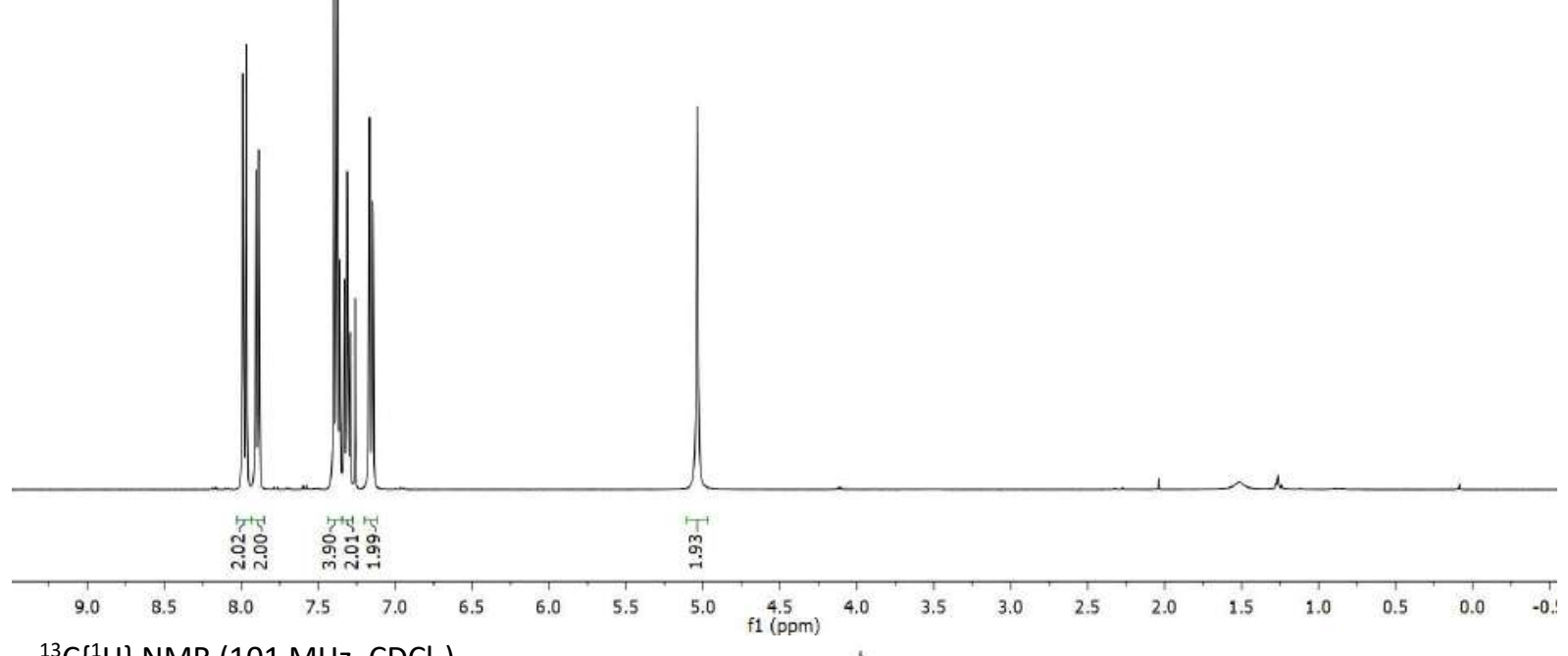

${ }^{13} \mathrm{C}\left\{{ }^{1} \mathrm{H}\right\}$ NMR (101 MHz, CDCl $)$
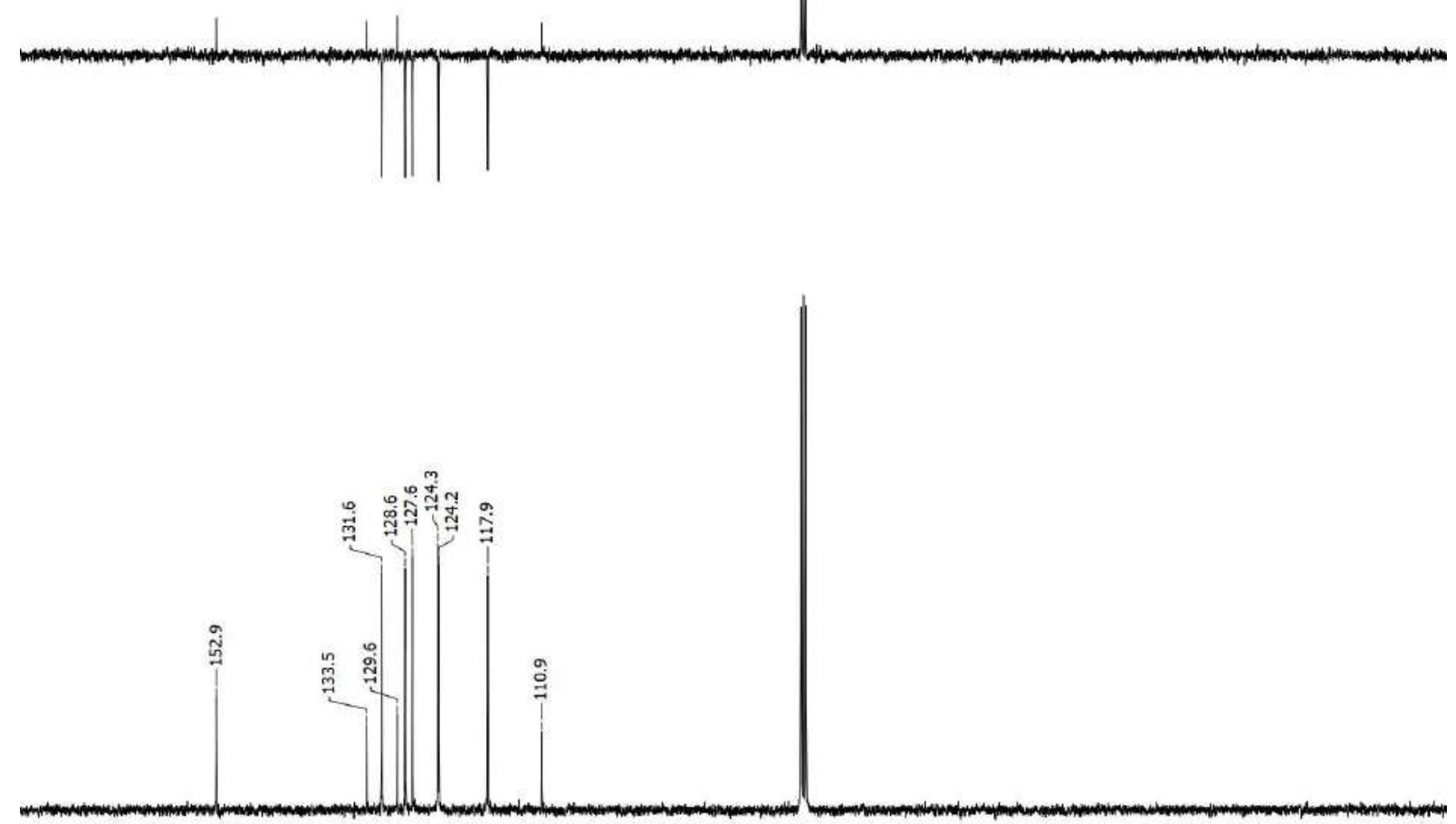
7,7'-dimethoxy-[1,1'-binaphthalene]-2,2'-diol (4b)

${ }^{1} \mathrm{H} \mathrm{NMR}\left(400 \mathrm{MHz}, \mathrm{CDCl}_{3}\right)$<smiles>COc1ccc2ccc(O)c(-c3c(O)ccc4ccc(OC)cc34)c2c1</smiles>

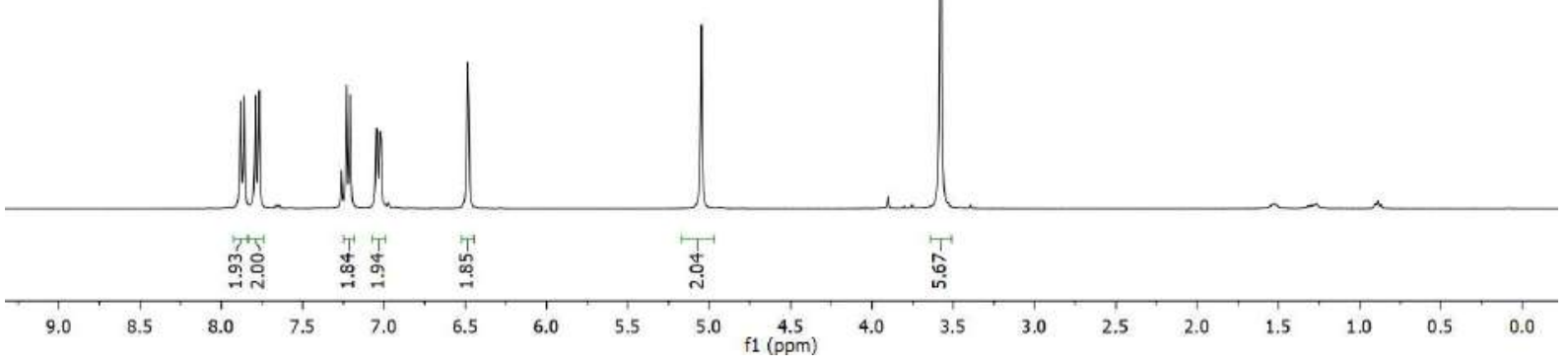

${ }^{13} \mathrm{C}\left\{{ }^{1} \mathrm{H}\right\}$ NMR (101 MHz, $\left.\mathrm{CDCl}_{3}\right)$
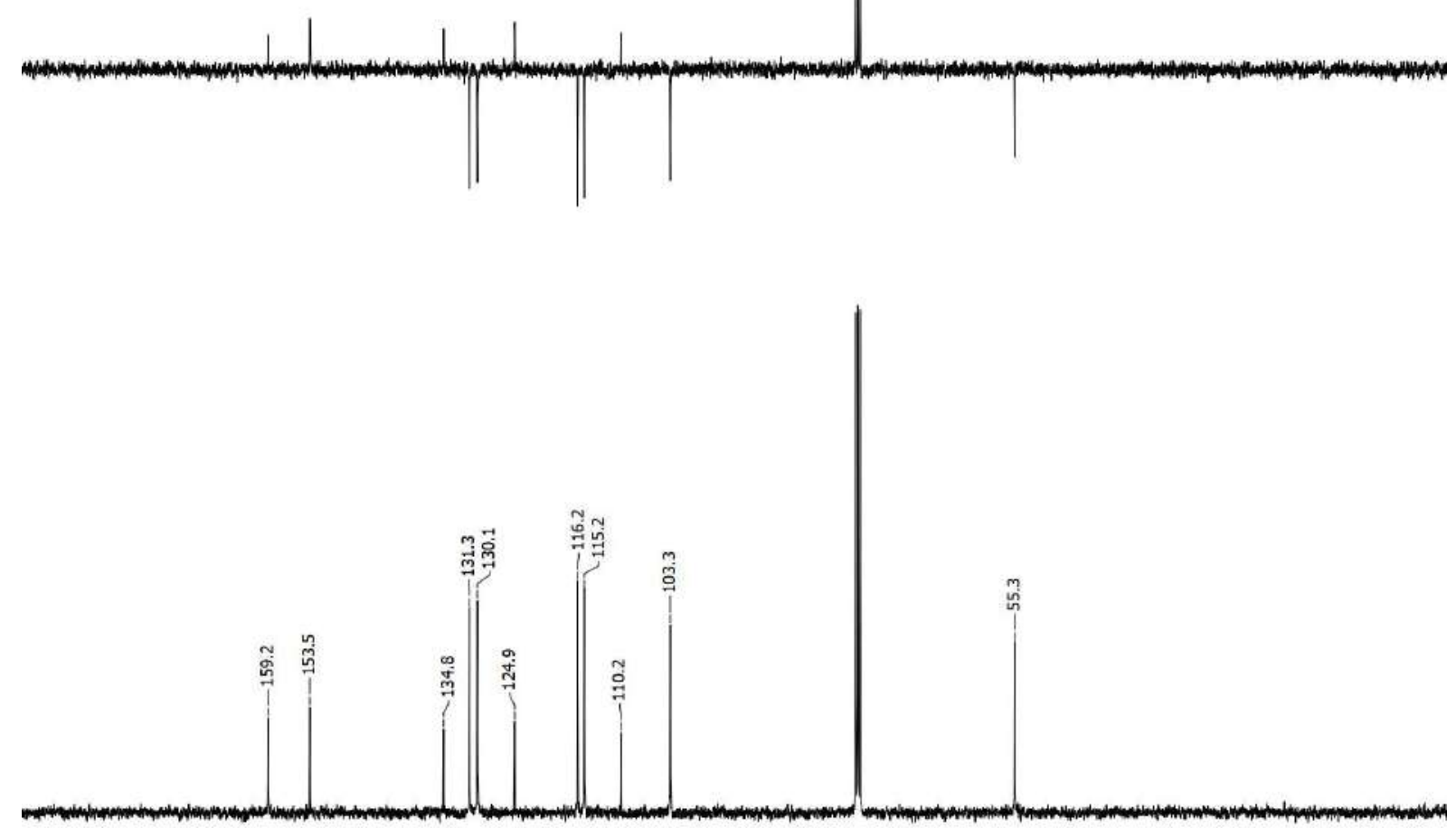


\section{6,6'-dibromo-[1,1'-binaphthalene]-2,2'-diol (4c)}

${ }^{1} \mathrm{H}$ NMR $\left(400 \mathrm{MHz}, \mathrm{CDCl}_{3}\right)$

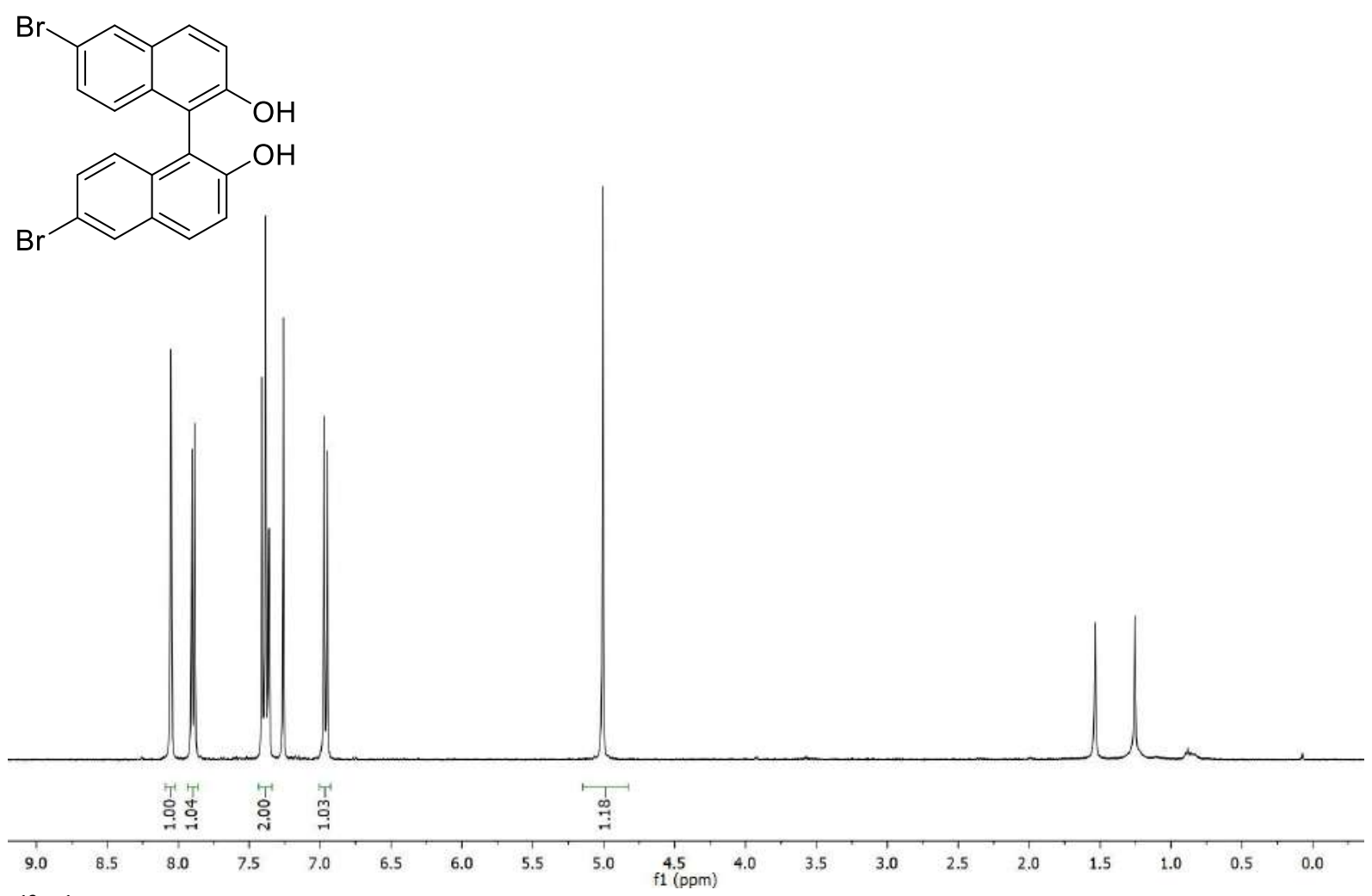

${ }^{13} \mathrm{C}\left\{{ }^{1} \mathrm{H}\right\}$ NMR (101 MHz, $\mathrm{CDCl}$ )
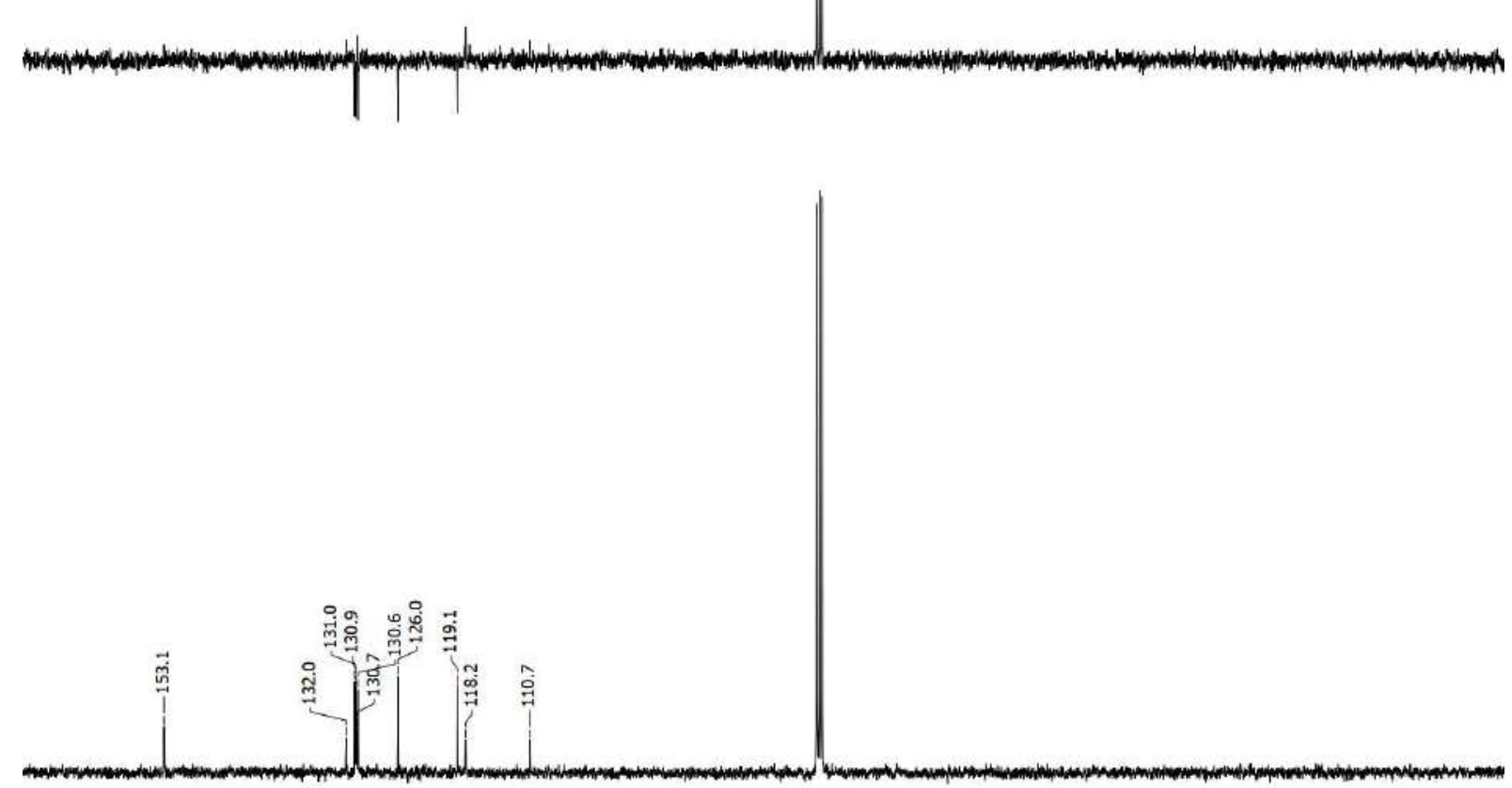


\section{3,3'-dibromo-[1,1'-binaphthalene]-2,2'-diol (4d)}

${ }^{1} \mathrm{H}$ NMR $\left(400 \mathrm{MHz}, \mathrm{CDCl}_{3}\right)$

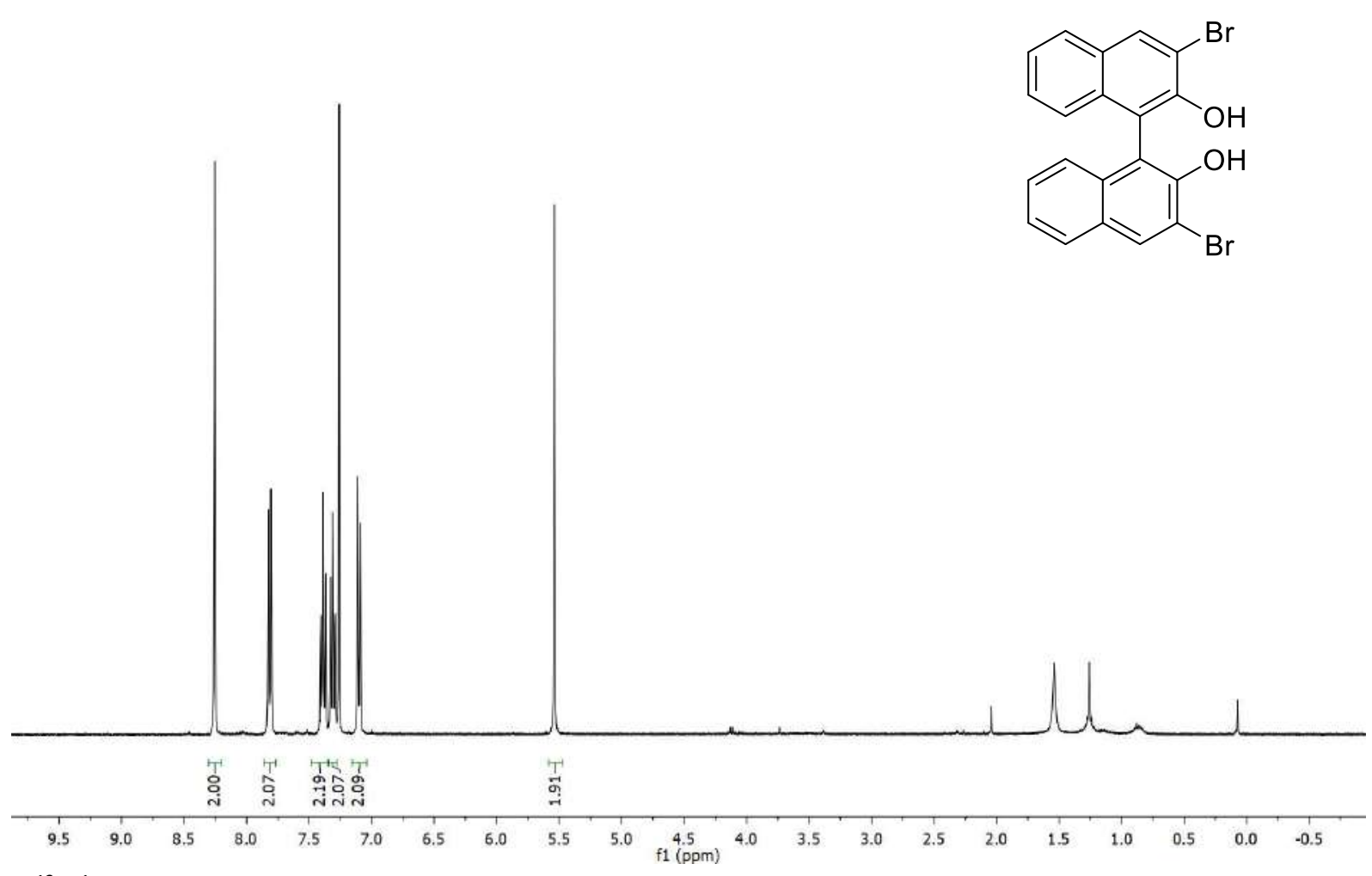

${ }^{13} \mathrm{C}\left\{{ }^{1} \mathrm{H}\right\}$ NMR $\left(101 \mathrm{MHz}, \mathrm{CDCl}_{3}\right)$

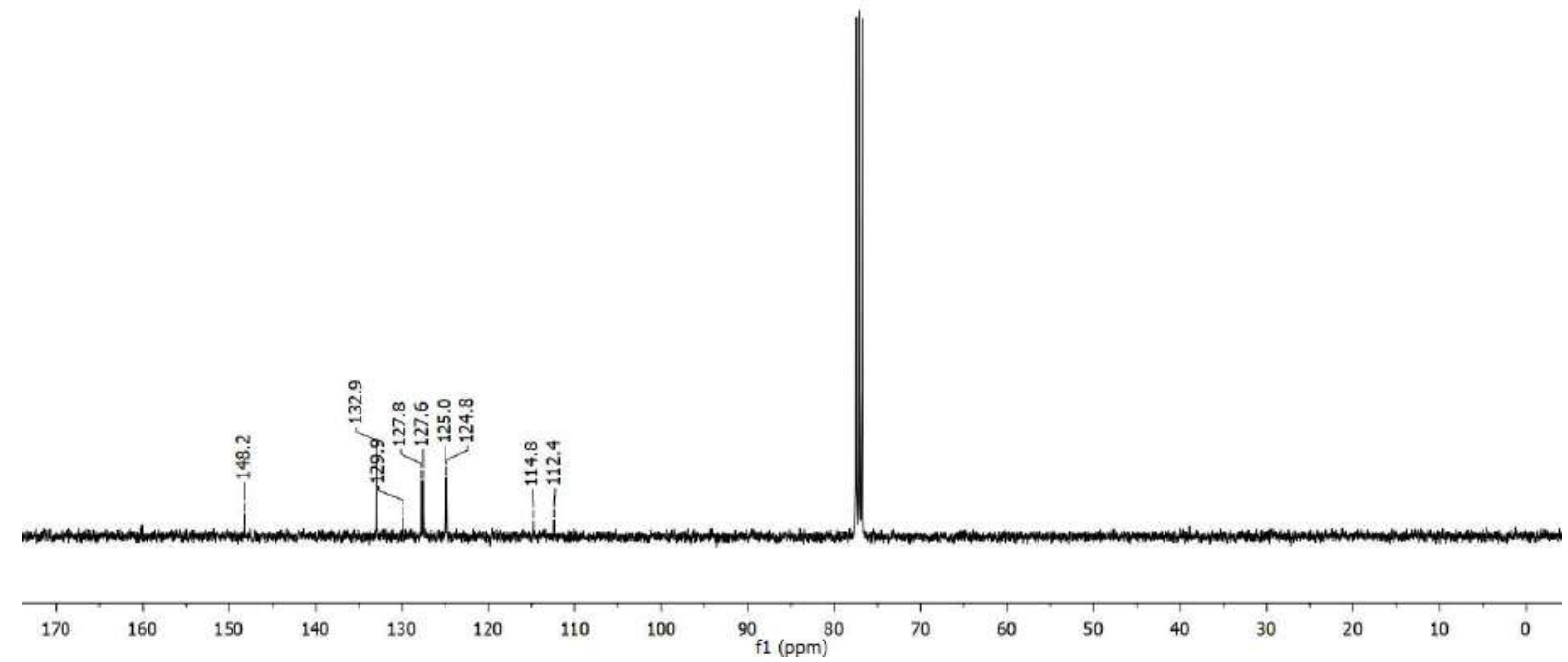




\section{6,6'-diphenyl-[1,1'-binaphthalene]-2,2'-diol (4e)}

${ }^{1} \mathrm{H}$ NMR (400 MHz, $\mathrm{CDCl}_{3}$ )
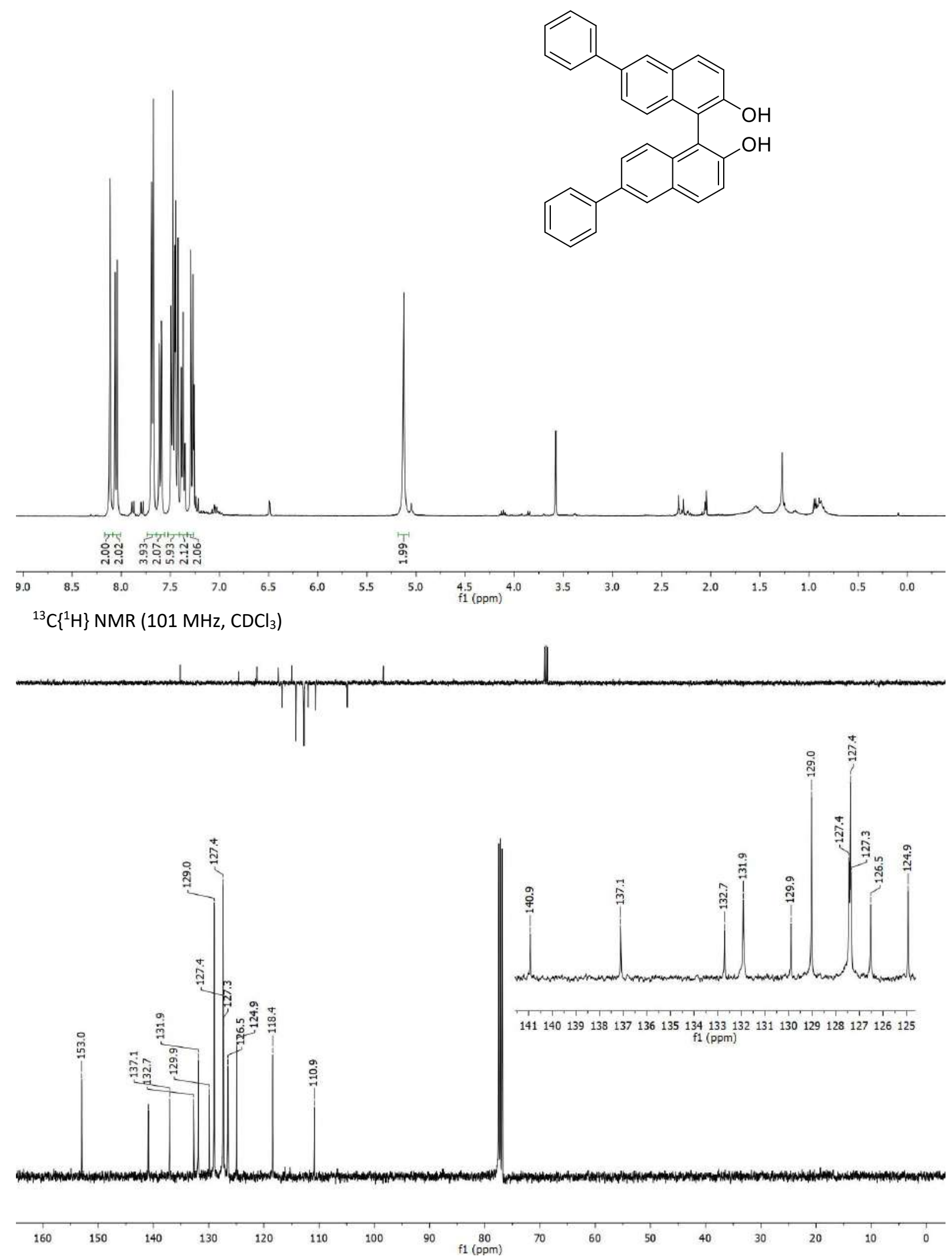


\section{[1,2':5',1":6",1'"-quaternaphthalene]-2",6'-diol (4f)}

${ }^{1} \mathrm{H} \mathrm{NMR}\left(400 \mathrm{MHz}, \mathrm{CDCl}_{3}\right)$

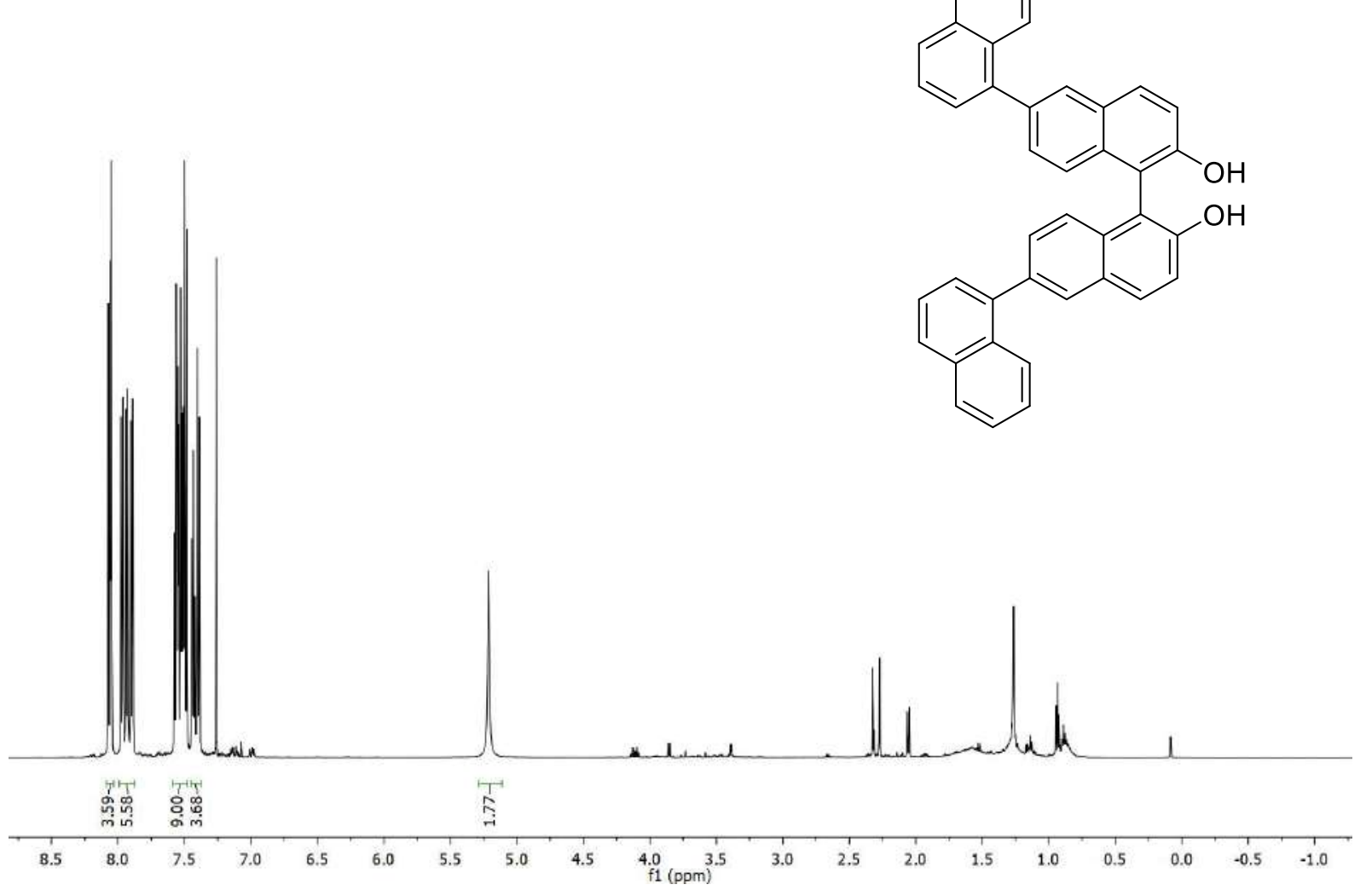

${ }^{13} \mathrm{C}\left\{{ }^{1} \mathrm{H}\right\}$ NMR $\left(101 \mathrm{MHz}, \mathrm{CDCl}_{3}\right)$
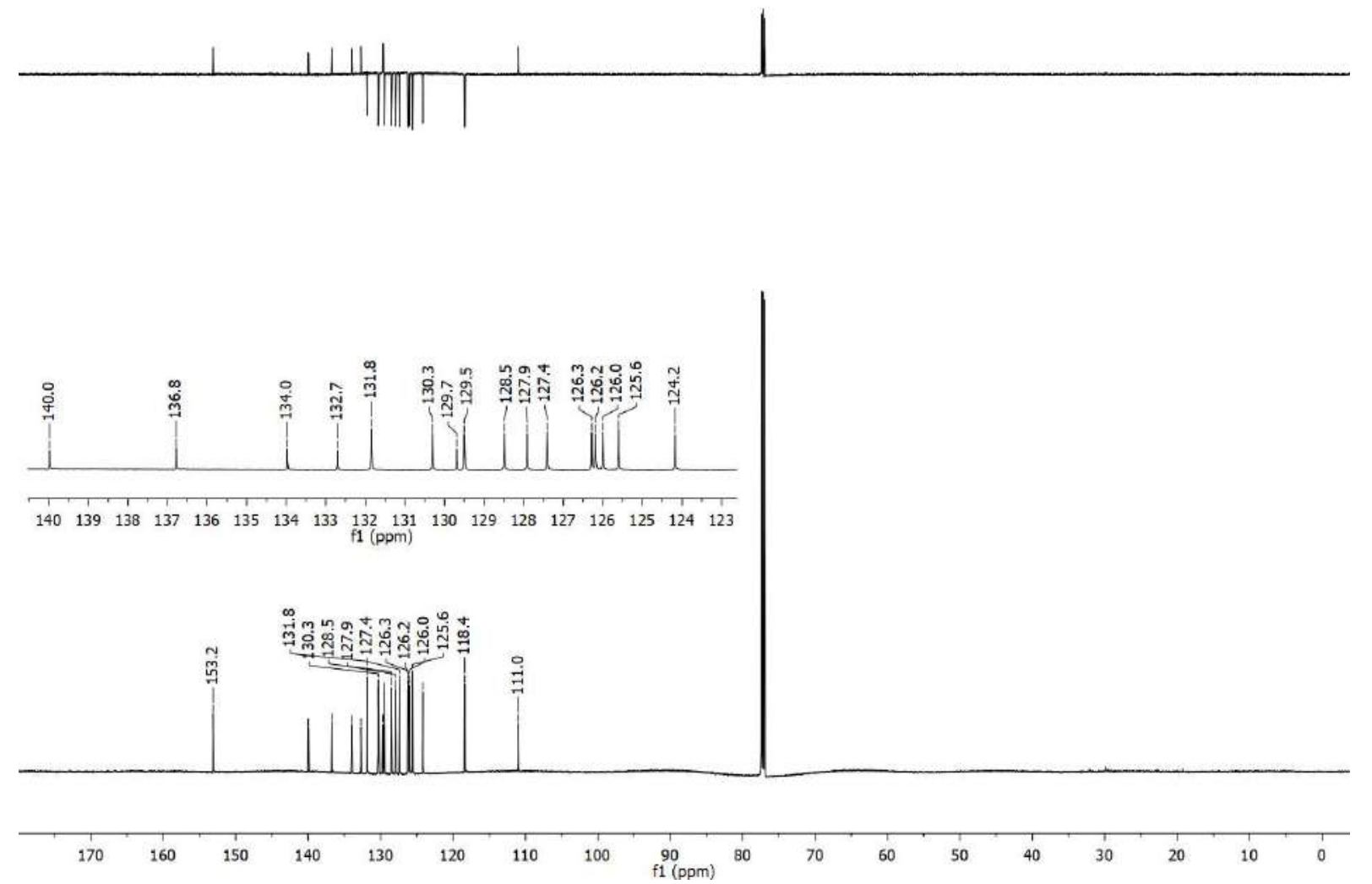


\section{Minerals PXRD and elemental analysis}

Code references:

Covellite - RWTHFPCUC

Bornite - RWTHFPCUB

Vanadinite - RWTHFPV1

PXRD analysis of the minerals used in this work
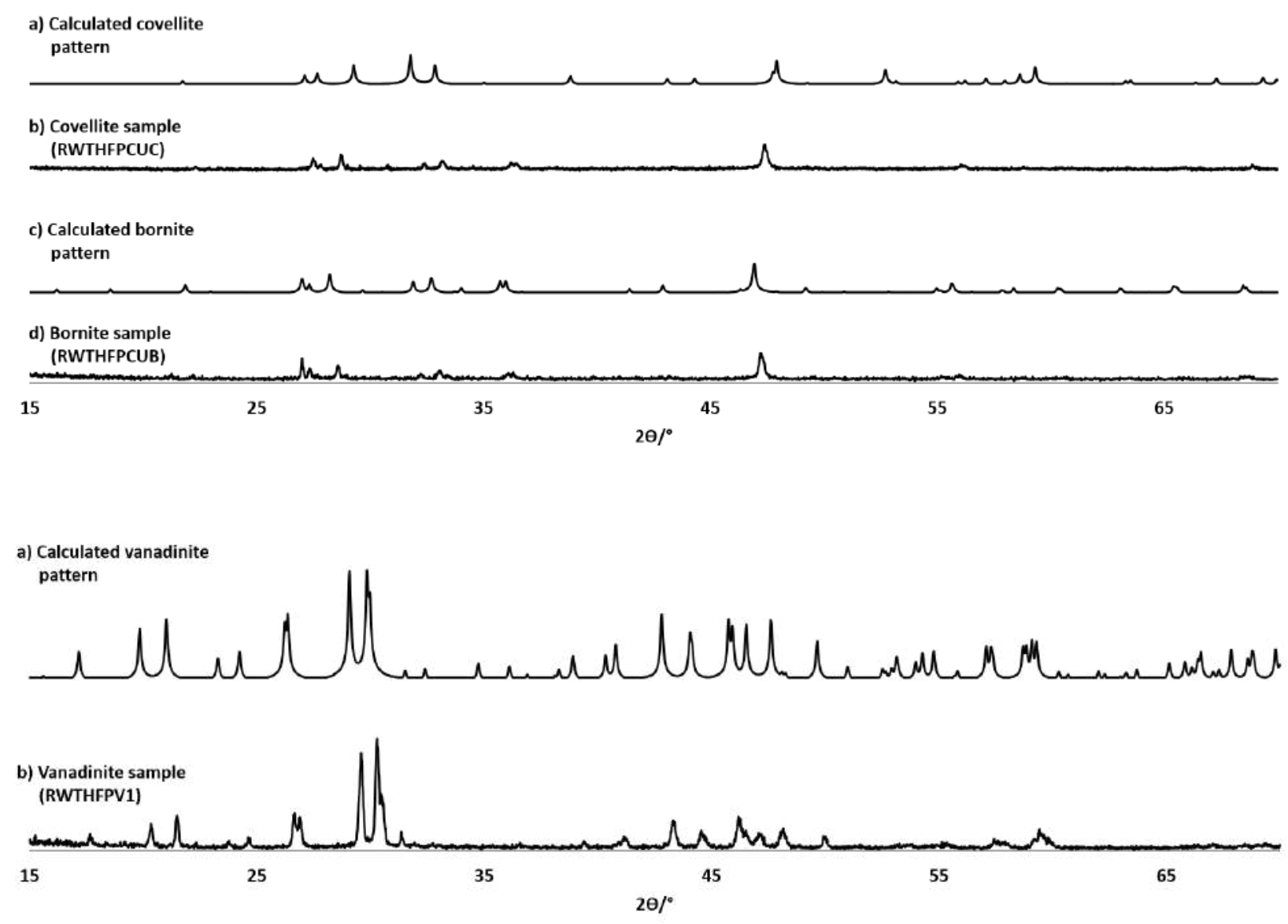
Elemental analysis of the minerals used in this work
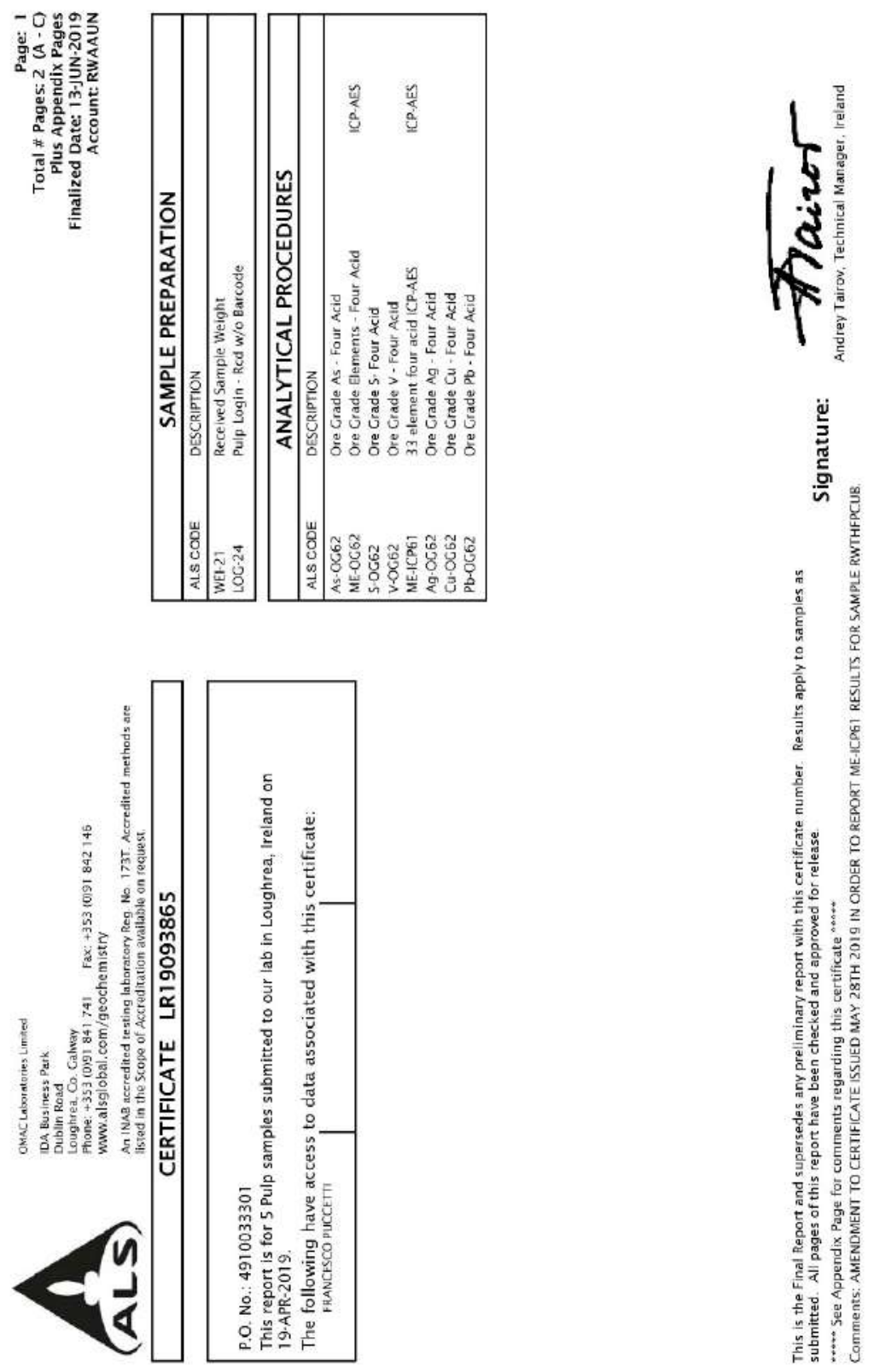


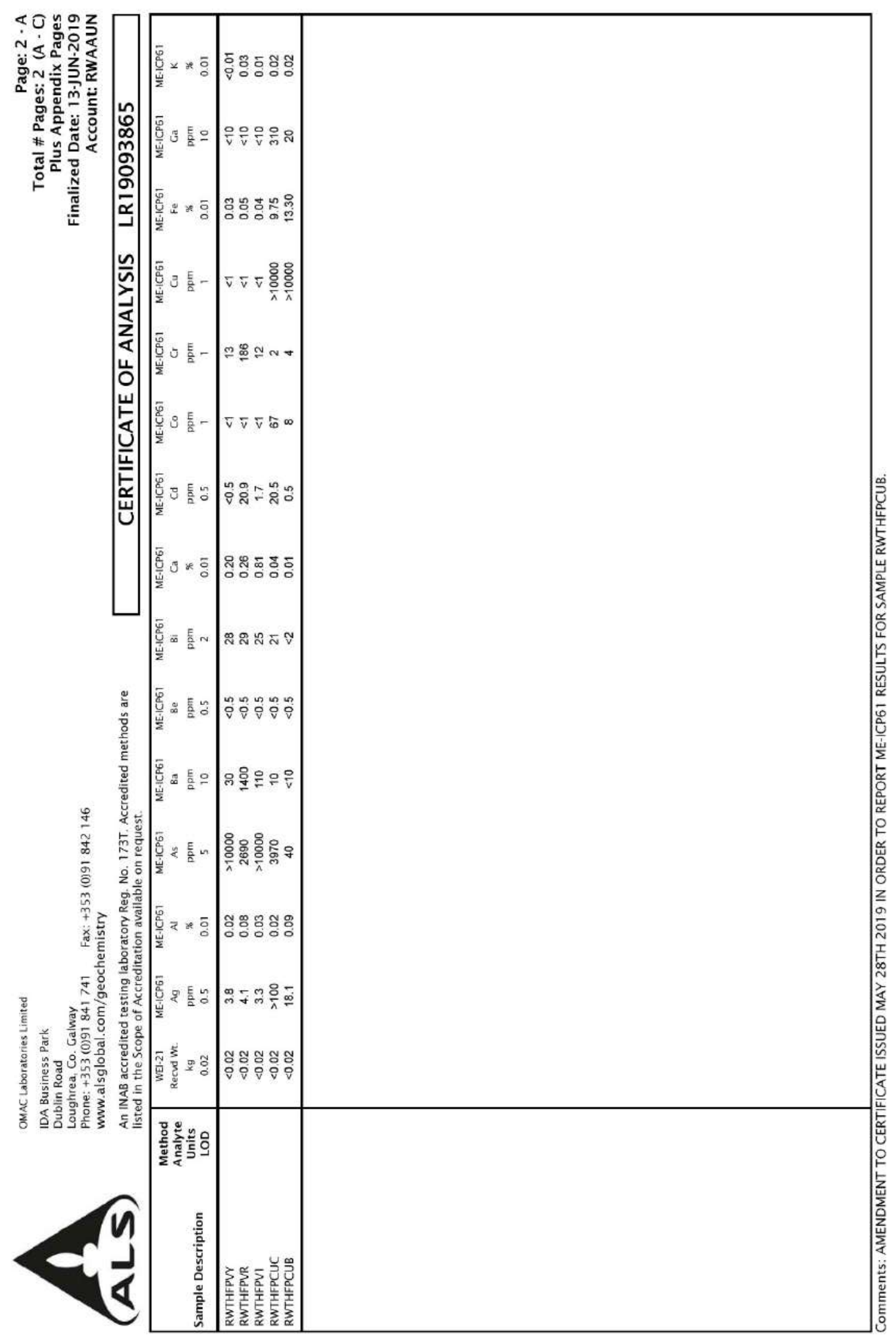




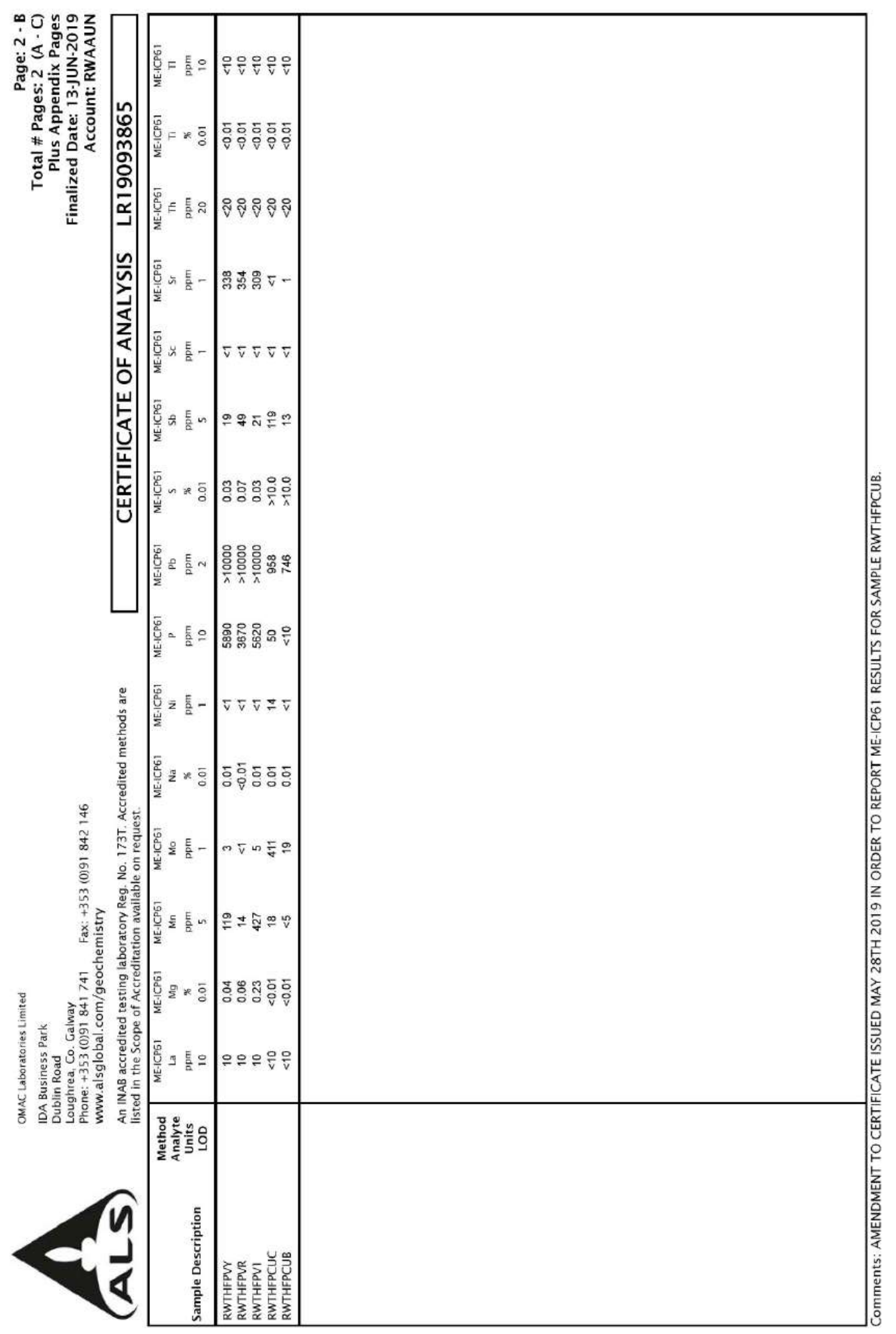




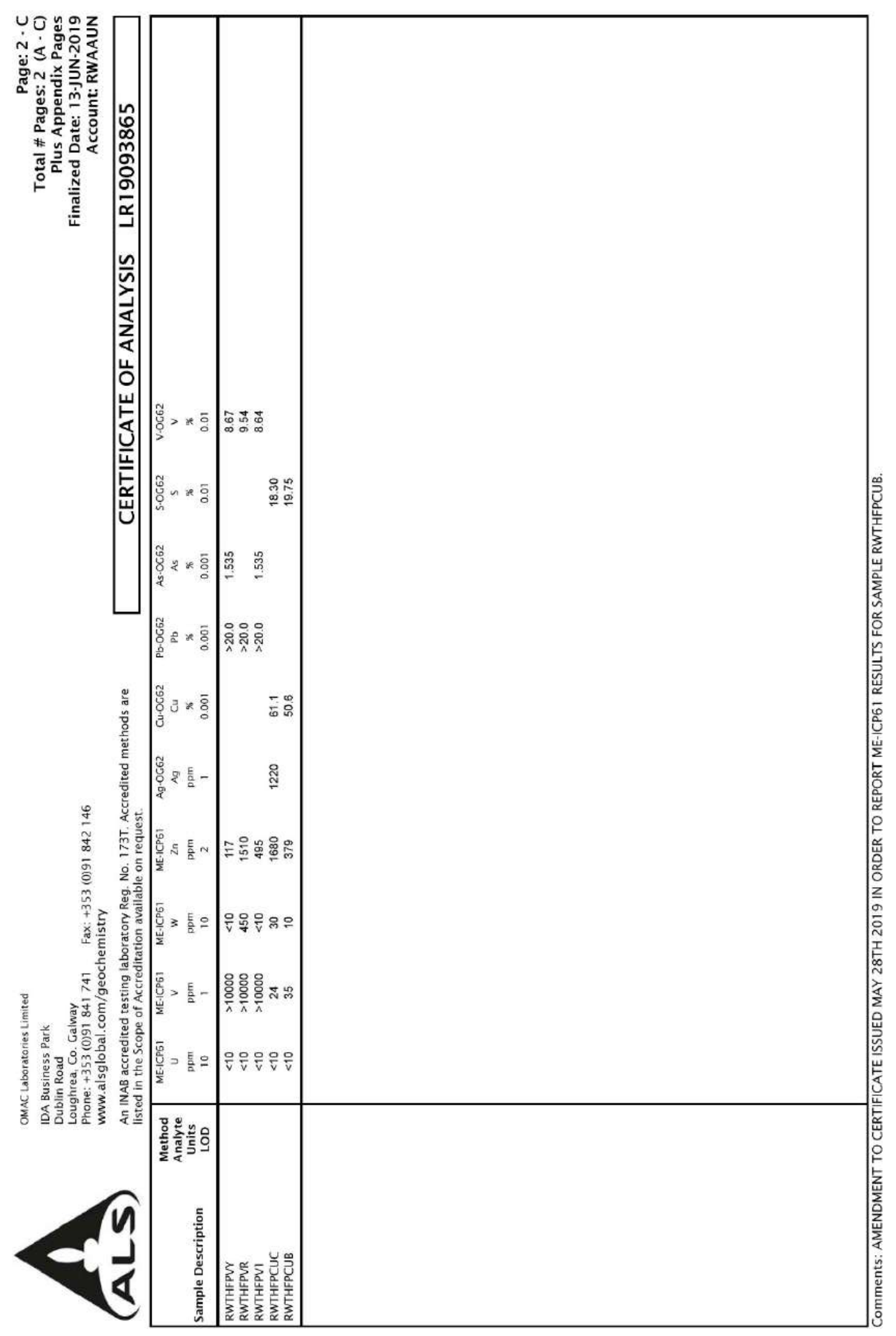




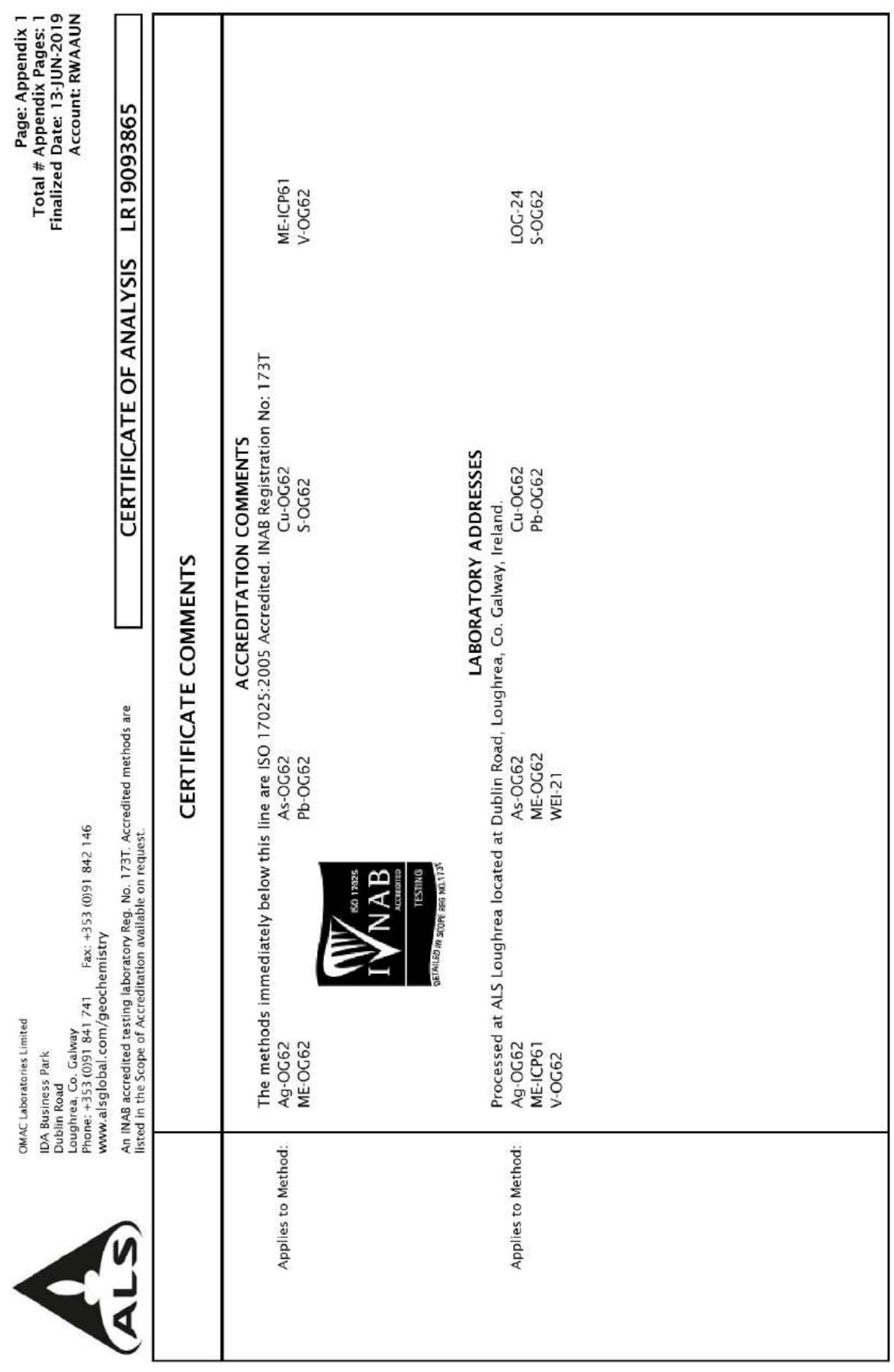


